\title{
A REVISION OF THE GENUS TETRATHECA (TREMANDRACEAE)
}

\author{
JoY THOMPSON
}

(Received 1975)

\section{ABSTRACT}

Thompson, Joy (National Herbarium of New South Wales, Royal Botanic Gardens, Sydney, New South Wales, Australia) 1976. A revision of the genus Tetratheca (Tremandraceae). Telopea 1 (3): 139-215.-An account is given of all species of the genus Tetratheca, in the endemic Australian family Tremandraceae. Thirty-nine species are recognized. New taxa described are T. retrorsa, $T$. paucifolia, $T$. similis, $T$. fasciculata, $T$, remota, $T$. deltoidea, $T$. parvifolia, $T$. elliptica, $T$. rupicola, $T$. decora, $T$. neglecta, $T$. insularis and $T$. pilosa ssp. latifolia. A new name $T$. labillardierei is provided and four overlooked names have been typified and correctly applied. [Plant Systematics].

\section{INTRODUCTION}

For many years the genus Tetratheca has been in such taxonomic confusion that very few specimens could be determined with certainty. This is an extraordinary situation in a group which is by no means rare and is a common component of the flora about Sydney as well as most other well-collected bushland areas of temperate Australia. The earliest collections of Tetratheca were suitably named but the differences between species are subtle and it was not long before other heath-leaved specimens were placed in "ericifolia" and glandular-haired specimens in "glandulosa" until the tendency to "lump" species triumphed and confusion abounded. Despite this the species of Tetratheca are actually very distinct.

Some species have a wide distribution but many have extremely localized distributions, so localized indeed as to suggest that other species may yet be undiscovered. The few "aberrant" specimens found in isolated places may represent species just as "good" as those well known ones which are readily accepted because their narrow range is in well-populated and familiar areas. Hybridization is extremely rare and only three or four specimens, in perhaps 3,000 examined, clearly indicate hybridization. However, some of the more widespread species include a series of intergrading forms. It would appear that the general pattern of variation in the west of the continent is similar to that in the east, with a few widespread, and many restricted species. Only further collecting will elucidate the problems that remain and confirm or otherwise the conclusions reached.

For this revision I have examined the collections of all major Australian herbaria. Because of the scope of the work I have relied for the most part on herbarium material and have drawn up most of the descriptions from dried specimens. For that reason they may not include features readily observable only in living material. Space has limited the number of specimens cited but those included give a representative geographical distribution for each species. The distribution maps are drawn up from all specimens examined. Except where otherwise stated I have examined all type specimens cited.

\section{The Position of Tetratheca within the Family Tremandraceae}

Tetratheca is one of three genera which constitute the small endemic Australian family Tremandraceae. The other genera, Platytheca and Tremandra, are confined to south-western Australia but Tetratheca is widely distributed across the southern part of the continent, see Map 2, p. 152. The three genera are closely related and form a satisfying family group. Platytheca and Tremandra, each in need of further collection and study, are distinctive and compact genera and differ markedly from one another. 
TABLE 1

\begin{tabular}{|c|c|c|}
\hline Platytheca & Tetratheca & Tremandra \\
\hline $\begin{array}{l}\text { Pubescence of various kinds } \\
\text { but never stellate }\end{array}$ & $\begin{array}{l}\text { Pubescence of various kinds } \\
\text { but never stellate }\end{array}$ & Pubescence stellate \\
\hline Leaves verticillate & $\begin{array}{l}\text { Leaves alternate, opposite or } \\
\text { verticillate }\end{array}$ & Leaves opposite \\
\hline Flowers pentamerous & $\begin{array}{l}\text { Flowers pentamerous or tetra- } \\
\text { merous }\end{array}$ & Flowers pentamerous \\
\hline $\begin{array}{l}\text { Upper part of the petal in the } \\
\text { bud with } 2 \text { longitudinal folds } \\
\text { and with the parts outside the } \\
\text { folds inrolled to either side of } \\
\text { the anther-tube but not en- } \\
\text { closing it }\end{array}$ & $\begin{array}{l}\text { Petal in the bud with } 2 \text { longi- } \\
\text { tudinal folds overlapping at } \\
\text { the top and enclosing the } \\
\text { bodies of the } 2 \text { anthers } \\
\text { Fig. } 3\end{array}$ & $\begin{array}{l}\text { Upper part of the petal in the } \\
\text { bud with } 2 \text { longitudinal over- } \\
\text { lapping folds enclosing a } \\
\text { single anther-body }\end{array}$ \\
\hline $\begin{array}{l}\text { Stamens in } 2 \text { series with the } \\
\text { outer series opposite the petals } \\
\text { and shorter than the inner } \\
\text { series }\end{array}$ & $\begin{array}{l}\text { Stamens in } 1 \text { series with a pair } \\
\text { of stamens opposite each } \\
\text { petal and all stamens of } \\
\text { equal size }\end{array}$ & $\begin{array}{l}\text { Stamens probably in } 1 \text { series } \\
\text { but with alternate stamens } \\
\text { opposite the petals, some- } \\
\text { what longer and with a } \\
\text { thickened disc-like structure } \\
\text { between each and the base } \\
\text { of its petal }\end{array}$ \\
\hline Anther-loculi 4, in 1 series & Anther-loculi 4 , in 2 series & Anther-loculi 4 , in 2 series \\
\hline Filaments stout and flat & $\begin{array}{c}\text { Filaments stout or filiform, } \\
\text { flat or terete, occasionally } \\
\text { absent }\end{array}$ & Filaments filiform and terete \\
\hline $\begin{array}{l}\text { Filaments broad at their } \\
\text { junction with the anthers }\end{array}$ & $\begin{array}{l}\text { Filaments broad or narrow at } \\
\text { their junction with the } \\
\text { anthers }\end{array}$ & $\begin{array}{l}\text { Filaments narrow at their } \\
\text { junction with the anthers } \\
\text { (but not articulate) }\end{array}$ \\
\hline Anther-tube long & $\begin{array}{c}\text { Anther-tube long, short or } \\
\text { absent }\end{array}$ & Anther-tube absent \\
\hline Ovary-loculi each with 1 ovule & $\begin{array}{l}\text { Ovary-loculi each with } 1,2 \text { or } \\
\text { many ovules }\end{array}$ & Ovary-loculi each with 2 ovules \\
\hline Ovule-appendage lacking & Ovule bearing an appendage & Ovule bearing an appendage \\
\hline $\begin{array}{l}\text { Seeds with inflated or flat } \\
\text { deflated hairs }\end{array}$ & Seeds pilose to glabrous & Seeds pilose \\
\hline
\end{tabular}

The most distinctive characters of each genus are set out in Table 1. It should be noted that the anthers of Tremandra are very similar to those of Tetratheca pilifera and cannot be used to distinguish the genera. They are neither articulate with the filaments as indicated by Bentham and Hooker (1862) and Hutchinson (1967), or 2-locular as given by Brown (1814), Smith (1817) and most later authors. I have given considerable thought to whether any species of Tetratheca would be better treated as a fourth genus but have concluded that the present traditional generic limits are quite satisfactory, as even the most divergent species are much closer to other species of Tetratheca than any species of Tetratheca is to Platytheca or Tremandra.

As can be seen from the table, the range of variation in Tetratheca is much greater than in the other genera, each of which consists of only 2 species. Tetratheca shares many characters with one or other of these genera and in some cases its species 
differ so widely that it shares characters with both. However, in the fundamental characters of aestivation and the arrangement of petals in relation to stamens all three genera differ so consistently as to suggest that they have all diverged from a common stock rather than that Platytheca and Tremandra are extreme off-shoots from a variable group represented by Tetratheca. The purple flowers and Tremandra-like stamens found in Tetratheca pilifera suggest some intergeneric hybridization in the recent past.

\section{Relationships within the Genus}

Relationships between species within Tetratheca are puzzling and the evolutionary trends are obscure.

The greater variety of characters in Western Australia, as well as the presence of two other genera sharing some of these characters, points to a western origin. No species is found on both sides of the continent and several western characters, such as pentamery and long anther-tubes, are completely lacking in the east. The western species would appear to be more closely related, in spite of their variation, to one another than to any eastern species, while the eastern species are closer to one another than to any western species. It appears that each half of the continent has produced a number of forms during a long period of isolation from the other but that Kangaroo Island has been colonized from both sides.

I have had considerable trouble in deciding the significance to allot to characters as indicators of relationships. Pentamery is significant in that it does not occur in eastern Australia, but in western Australia certain species produce both 4- and 5-merous flowers and there are also 4-merous species.

A number of species can be paired or associated in small groups. In each case the resemblance is in more than one feature and the relationship obvious. Ovulenumber is all-important since multiple- and single-ovuled loculi do not both occur in closely linked species. Stem-pubescence or an unusual floral character often provides additional support for the grouping. The relationships of these groups to one another and of all other species to these groups is a subject for conjecture.

The following groups can be recognized:

$T$. affinis, $T$. efoliata and $T$. retrorsa

$T$. aphylla and $T$. paucifolia

$T$. halmaturina and $T$. harperi

$T$. hispidissima and T. hirsuta

$T$. confertifolia and $T$. filiformis

T. glandulosa and T. labillardierei

$T$. stenocarpa and $T$. ciliata

$T$. rupicola and $T$. thymifolia

T. pilosa, T. gunnit, T. neglecta, $T$. rubioides and $T$. insularis.

It seems likely that the $T$. pilosa group originated in Tasmania and spread to the northwest and northeast. T. glandulosa may have separated in the north from the 
MAP I

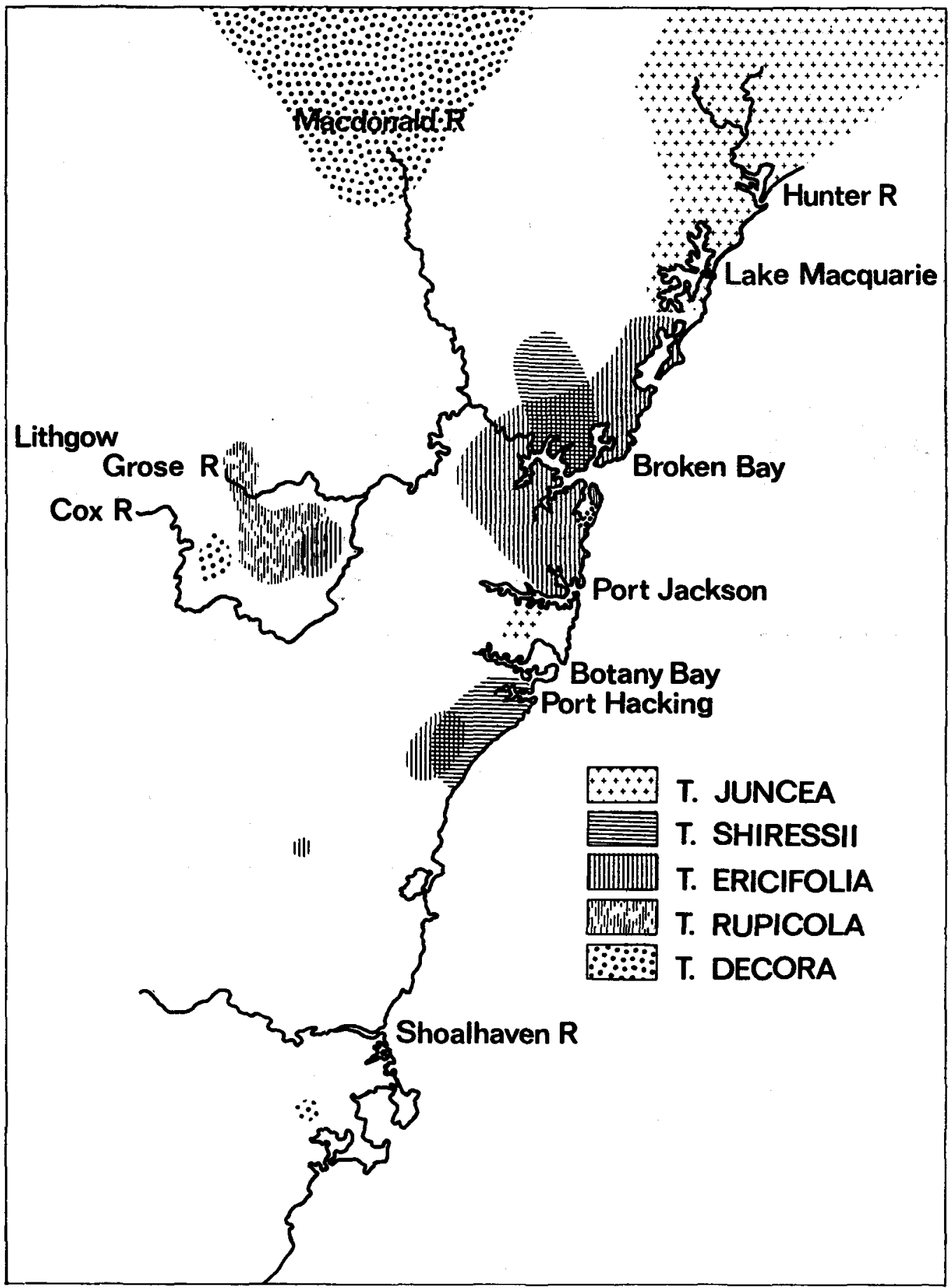


MAP Ia

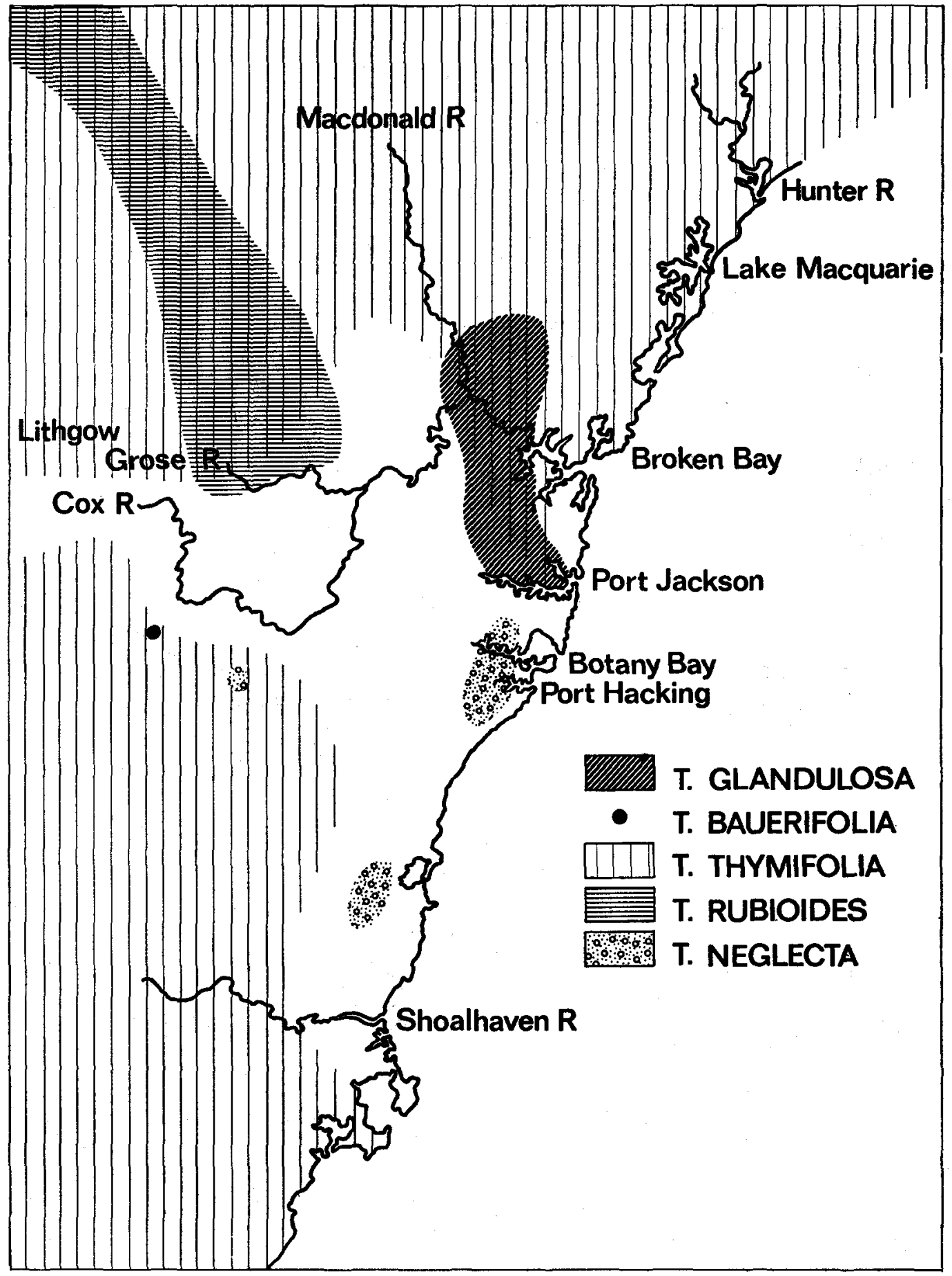


more wide-ranging $T$. labillardierei. $\quad T$. hispidissima may have separated in the east from the widespread $T$. hirsuta. However the origins and links of most species are obscure.

\section{Habitat and Species Distribution}

Tetratheca, though widespread, is restricted in its habitat to sandy or gravelly soils in heath and sclerophyll forest. The species are often found among rocks and occasionally in swamps but even here they are probably in the loose sandy soil of sandstone or granitic origin to which they seem so well adjusted. On the whole the species do not stand up well to competition and are usually most abundant in areas, often disturbed bushland, where the poverty or loose nature of the soil places other plants at a disadvantage.

Some species have a broad geographical distribution, others are extremely restricted. T. decora is widely disjunct but vigilance in the less accessible sandstone areas of central New South Wales will probably bring more localities to light. Altitude seems to have little effect. T. thymifolia and T. pilosa are common at sea level and found at very high altitudes as well.

Unfortunately I have not had the opportunity of making field observations in Western Australia and it may therefore be unwise to generalize about the habitats of Western Australian species. Such few field notes as are found on specimens indicate that these species' requirements parallel those of Eastern Australian species.

The pattern of distribution of the ten species found within $150 \mathrm{~km}$ of Sydney is most interesting, see Maps 1 and 1a. This area includes The Royal National Park, $\mathrm{Ku}$-ring-gai Chase National Park and the Blue Mountains and is very well collected. As a result we can regard as significant the gaps in the distributions of common species. $T$. juncea is not found between Broken Bay and Botany Bay. $T$. decora has only one known occurrence in the Sydney district, at Ingleside; the nearest others are in the Coxs and Macdonald River areas. T. neglecta is found only south of Port Jackson; $T$. glandulosa only north of Port Jackson. $T$. ericifolia has only scattered occurrences south of Port Jackson but is common on the North Shore. On the Blue Mountains T. rupicola is rarely north of the Grose River. T. rubioides is rarely south of the Grose River but occurs south of the Shoalhaven River on the Southern Tablelands. T. bauerifolia is found only near Kanangra. The widespread T. thymifolia occurring from Queensland to Victoria avoids the central coast of New South Wales from Port Jackson to the Shoalhaven River. So within the Sydney district, in what would all be considered sandy heath and sclerophyll forest, each species obviously has particular requirements. Perhaps now that the taxonomy is clarified it will be possible to establish the significance of the pattern.

\section{EVALUATION OF CHARACTERS}

\section{Habit}

All species of Tetratheca are small perennial shrubs, the largest rarely above $1 \mathrm{~m}$ in height (up to $1.5 \mathrm{~m}$ in $T$. retrorsa); the smallest is the high altitude form of $T$. pilosa with procumbent stems a few centimetres in length. Most species are compact, many-stemmed, heath-like or leafless subshrubs of considerable superficial similarity. Some species, however, especially those which grow under trees, have a more diffuse or even trailing habit. In the majority of species the base of the plant consists of a branched stock from which a few or many, rather woody, slender stems arise and from which slender woody rhizomes extend giving rise irregularly to single stems or clusters of stems. Tetratheca is often found in dense low thickets on unstable new road verges, while in the same area in undisturbed woodland the plants are isolated 
and much less robust. I have observed this in T. thymifolia and T. pilosa; and Dr N. T. Burbidge (pers. comm. 1972) in T. bauerifolia. Smith (1805) describes plants of $T$. ericifolia and $T$. glandulosa as "burnt down to the root and ... grown up again." While this habit undoubtedly aids recovery after fire it probably has equal significance in assisting plants to survive changes in soil level in the loosely compacted soil in which they are found. Dr M. D. Tindale (pers. comm. 1972) has observed a pattern of flower-colour in $T$. rupicola which suggests clonal distribution. From the small amount of material available, $T$. fasciculata with its numerous stems arising from the top of a thick unbranched stock and no evidence of rhizomes, seems markedly distinct from all other species.

\section{Stems}

The majority of species of Tetratheca can be identified from their stems and in most cases a few centimetres length of stem would provide several valuable diagnostic characters. T. affinis and $T$. juncea have winged stems but the other species, although in general terete, are variously ridged or wrinkled, at least in dried specimens. The stems of several arid-country species are glaucous or grey-green, while those of $T$. efoliata are also flexuose or zigzag. Several of the sparsely-leaved species have stems ending in a point which can be quite stiff and blackened.

The thickness of the stem in terete-stemmed species is a useful character and for the majority of species it is reasonably constant in the flower-bearing region. Measurements have been made in this region on each specimen and stems $<0.8 \mathrm{~mm}$ thick described as "slender" and $>0.8 \mathrm{~mm}$ thick as "stout."

\section{Fig.1 STEM HAIRS}

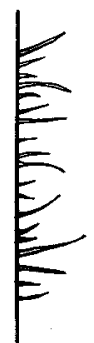

T.CILIATA

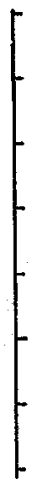

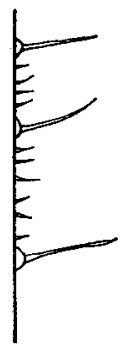

T. PILOSA

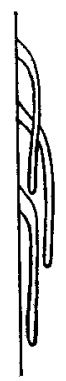

T. RETRORSA<smiles>C=C=C=C=C=C=C=C=C=C=C=C=C</smiles>

$\hat{E}$

T.ERICIFOLIA T.RUBIOIDES
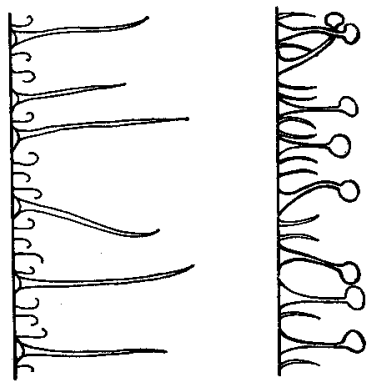

T.SETIGERA T.LABILARDIEREI 
The most useful diagnostic character is pubescence of the stems, see fig. 1. Stems are rarely completely glabrous and even when they approach this condition some specimens bear a few hairs, especially on the lower part of the plant. Most species have stems covered with large and/or small tubercles as well as several different kinds of hairs. Hairs may be tubercle-based and/or gland-tipped, coarse or fine, long or short, straight or curved or curled, antrorse or erect or retrorse, sparse or dense and white- or pale- or dark-coloured. In each species there is a characteristic hair-type or more frequently a combination of hair-types, although specimens occur in which hairs of one or more kinds are particularly strongly developed or are scarce or absent. The presence or absence of glandular tips is variable and may be correlated with climatic factors. Certainly both gland-tipped hairs and setae, when they occur in the species, are more frequent on younger growth.

The branching of the stems also varies. It is usually alternate but is often irregularly verticillate in species which have whorled leaves. In species such as $T$. efoliata and $T$. harperi the leaf-clusters seem to indicate complete reduction of sidebranches. Internode-length has not proved useful in distinguishing species.

\section{Leaves}

In the majority of species the leaves are alternate, i.e. spirally arranged, although in a number they are consistently verticillate in whorls often of up to 6 leaves. In many species, however, the leaf-arrangement is not constant: alternate, opposite and whorled leaves may be found on one plant. In $T$. pilosa whorled leaves are common (though not consistently so) only in ssp. latifolia. Some species have their leaves reduced in the flowering region of the stem, as in $T$. stenocarpa where the ultimate flowers may be subtended by deltoid scales. In many others, especially in Western Australia, leaves are suppressed or soon deciduous over most or all of the plant.

Leaves in Tetratheca are rarely more than $2 \mathrm{~cm}$ long, and usually much shorter. They vary in shape from almost orbicular, deltoid or rhomboid, to linear, but the predominant shape is elliptical. The margins may be flat or variously recurved to revolute and are usually entire. If they are somewhat dentate, the teeth usually bear setae. The amount of rolling of the leaves is relatively consistent in most species, although external conditions can influence it. $T$. thymifolia may have revolute leaves in exposed coastal conditions; $T$. hirsuta may have flat leaves in shady conditions. There is a tendency for leaves of the $T$. pilosa group to roll over the midrib while in $T$. rupicola they roll up to the sides of the midrib. The apex is obtuse to pungent-pointed with the point usually incurved. The apex and its point are generally not reliable diagnostic features but the acute and usually pungent leaftip of $T$. rupicola distinguishes it from the more rounded leaf-tip of the superficially similar $T$. rubioides. The lower leaf-surface is usually paler (particularly so in $T$. ciliata) and more glabrous than the upper. The upper surface may be glabrous but usually bears few or numerous long and/or short hairs and frequently tubercles, especially towards the margins. The petiole is short or absent. Occasionally it bears some hairs and often in Western Australian species there are setae at the base resembling stipules.

\section{Flowers}

The flowers usually occur singly, or in some species several together, in leafaxils on the upper part of the stem. They are usually subtended by bracts which vary in size from minute to more than $3 \mathrm{~mm}$ long. These often tend to resemble the leaves in shape and pubescence, although in most species they are concave, linear-lanceolate, somewhat pubescent, brownish structures of little diagnostic value. $T$. filiformis and $T$. confertifolia apparently lack bracts. Infrequently a bract may be found above the base or even near the middle of the peduncle. In one inflorescence, an aberration in $T$. labillardierei, 2 flowers were observed, each with a pedicel of equal length to the peduncle. Unfortunately in a group whose relationships 
are so obscure it is difficult to determine the orientation and identity of the structures in the leaf-axils of some species and to determine which should be called bracts and which reduced leaves or even reduced shoots. This problem arises with species such as $T$. affinis, $T$. retrorsa and $T$. harperi where there appear to be clusters of bracts at the base of the peduncle.

\section{Peduncles}

The peduncles are often dark in colour, probably reddish in living plants. In some species, as in $T$. nuda, they are uniformly short and in others, as in T. ericifolia, they are uniformly long but in most they are somewhat variable and may lengthen considerably as the flower matures. In many species the peduncles have a distinct twist or curve either at the base or near the top. In all species the upper part of the peduncle is expanded to form a receptacle, from less than $1 \mathrm{~mm}$ in $T$. filiformis and $T$. subaphylla to $3 \mathrm{~mm}$ wide in $T$. efoliata. In some species the expanded part is ridged or angled. The width of the receptacle is a very useful diagnostic character.

The type or combination of types of hair on the peduncles is also of diagnostic value; the presence or absence of hairs is less important. T. setigera can be readily determined by the long, stiff, antrorse setae on the peduncle when these are present.

In some species, especially in the $T$. pilosa group, the peduncle bears minute shining spots.

\section{Calyx}

The calyx in Tetratheca consists of free, equal segments arranged around the rim of the receptacle. There are 4 segments in all Eastern Australian species, except $T$. halmaturina of Kangaroo Island, but most Western Australian species and $T$. halmaturina have 5. In some western species both 4- and 5-merous flowers appear to be normal. Occasional specimens, in many species, show aberrant segmentnumbers. The segments are frequently dark in colour. Although in general ovate in shape, they may be deltoid, elliptical or even orbicular, while the apex may vary from obtuse to acuminate. The shape has some diagnostic value.

A more useful character is found in the pubescence. Unfortunately glabrous individuals occur in species characterized by a particular type of calyx-pubescence. Also glandular hairs may be found in occasional specimens of species which normally lack them. In some species, especially of the $T$. pilosa group, the calyx-segments may bear minute shining spots. The calyx-segments of a majority of the species have a fringe of fine hairs near the margin on the inner surface. This is especially noticeable in the reflexed calyx of $T$. ciliata.

In $T$. decora, $T$. glandulosa and $T$. labillardierei the segments are attached on the edge of the receptacle. However, in all other species, each segment is attached inside the top of the receptacle and is recurved against it so that its base is concealed, see fig. 2. Often there is a thick ridge across the lowest visible part and/or a turgid central thickening. This is a most useful character especially in western species.

The calyx-segments are usually readily deciduous but, because of a lack of articulation between the base of the segment and the receptacle, they are persistent in $T$. glandulosa and usually in $T$. labillardierei. They are also persistent around the fruit in $T$. paucifolia.

\section{Petals}

The petals are usually a deep lilac-pink. A number of fresh specimens have been matched to the Royal Horticultural Society Colour Chart colours $70 \mathrm{~B}$ and $72 \mathrm{C}$ but the range is wider than this and colour may vary in a single species. $T$. rupicola has been observed to have flowers of various shades of pink. Many species have frequent white-flowered plants and intermediates between pink and white are not uncommon. One specimen of $T$. pilosa is said to have had pink and white 
Fig. 2 RECEPTACLE AND CALYX (seen from outside)

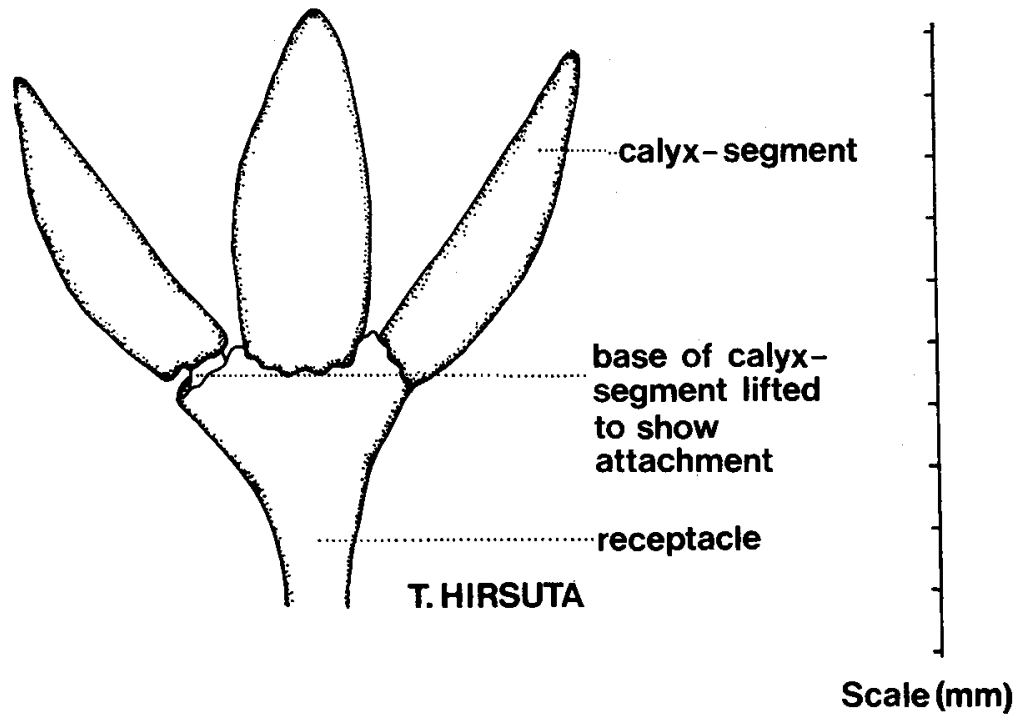

Fig.3 PETAL IN UNFOLDING FLOWER (seen from inside)
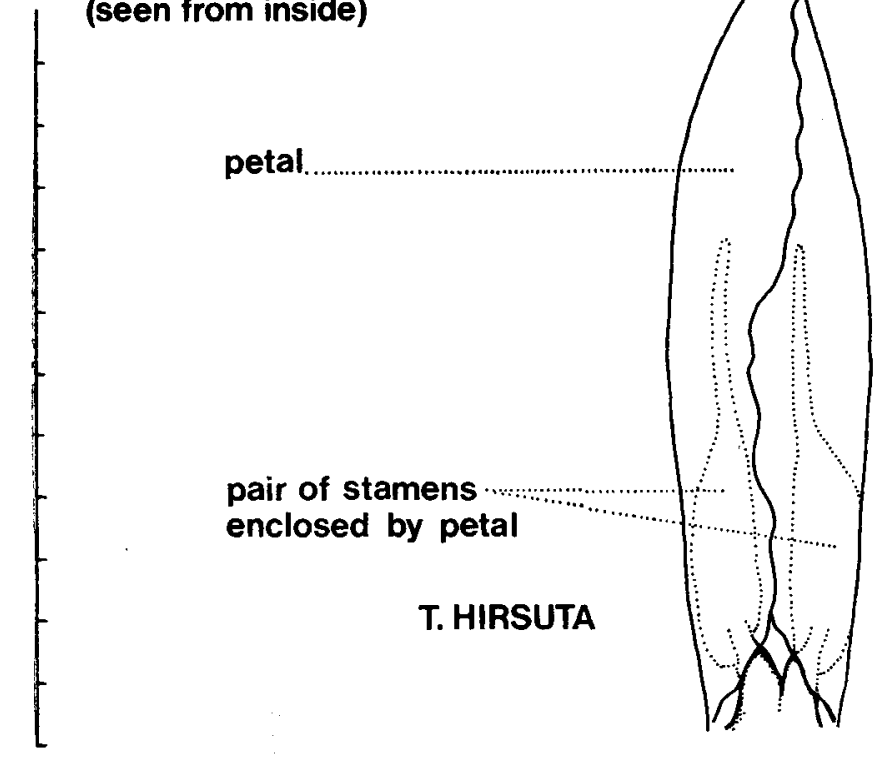

Scale $(\mathrm{mm})$ 
branches on the same plant. T. hirsuta, $T$. virgata and perhaps other western species have a dark patch at the base of each petal, others, as $T$. harperi, have dark lines at the base. T. pilifera has purple flowers, dark at the centre.

The number of petals corresponds with that of the calyx-segments, although "double" flowers have been observed. The dimensions of the petals vary from less than $5 \mathrm{~mm}$ to $20 \mathrm{~mm}$ in length and vary within and between species. Shape has been described in the majority of species as "linguiform" as, in two dimensions, it resembles a tongue with the base somewhat variably attenuate. Some species have obovate, elliptical or even ovate petals. All petal measurements in this paper have been taken from dried specimens soaked in detergent.

The petals are usually readily deciduous and fall before the ovary commences to enlarge. However they often tend to persist in $T$. labillardierei and remain around the fruit in $T$. glandulosa.

\section{Stamens}

The stamens are always twice as many as the petals and in the bud are enfolded in pairs by the petals. There is a certain similarity in the stamens of the majority of eastern species but a few eastern and almost all western species exhibit a remarkable diversity, see fig. 4 . The stamens vary in length from 1.5 to almost $7 \mathrm{~mm}$ but are usually rather uniform in size within the species. Most are dark red, purple or black and many have yellow tips. T. pilifera usually has yellow stamens. In some species, notably $T$. hirsuta, they are joined to a greater or less degree in pairs at the filament. The filaments vary in shape between the species. They may be stout or slender and terete or flattened. Some are minute others over $2 \mathrm{~mm}$ long, some very slender, others over $1 \mathrm{~mm}$ wide. In some species the filament merges imperceptibly into the anther while in others the transition is very abrupt. The filament is absent in $T$. deltoidea.

The anther consists of four loculi, the 2 larger behind the two smaller cells, forming the "body" of the anther, all discharging pollen through a common apical tube or pore. The walls between the lateral cells may sometimes disintegrate before maturity. The body may vary in length from 1 to $3 \mathrm{~mm}$ and either (a) tapers into the filament and above this is curved or angled, or (b) is abruptly swollen, especially at the back, above the filament. It may be smooth and shining or minutely tuberculate and/or with short stiff hairs or scabridities. At the top the body gradually or suddenly contracts into the tube. The shape of the body, though some variation must be allowed, is characteristic for the species. The tube has reached its maximum development and differentiation in the western species. It is often $2-3 \mathrm{~mm}$ long but in some species is short or absent. It may be strongly or slightly curved or straight, and often tapers towards the orifice. In T. hirsuta, T. hispidissima and $T$. virgata it is covered with minute tubercles. The orifice is broad or narrow, oblique or straight and with or without 2 conspicuous lips. Allowing for some variation in the orifice, the shape and length of the anther-tube is a most valuable aid to the recognition of species.

\section{Gynoecium}

The style varies from 1 to more than $4 \mathrm{~mm}$ in length. In some species it is consistently long and slender and in others broad, especially near the base, and relatively short. There are often hairs on the base of the style which conform with those on the ovary. Aberrant styles splitting into 2 are occasionally seen.

The ovary consists of 2 loculi, although aberrant trilocular ovaries are occasionally observed. It is always narrowest at the septum; the top is either rounded or tapers into the base of the style, except in $T$. decora where it is emarginate, and the base is often broad or even swollen. The pubescence of the ovary is a very useful diagnostic character. It may vary within a species, as in $T$. rupicola and $T$. bauerifolia, but for the majority of species the pubescence is consistent. 
Fig. 4 STAMENS
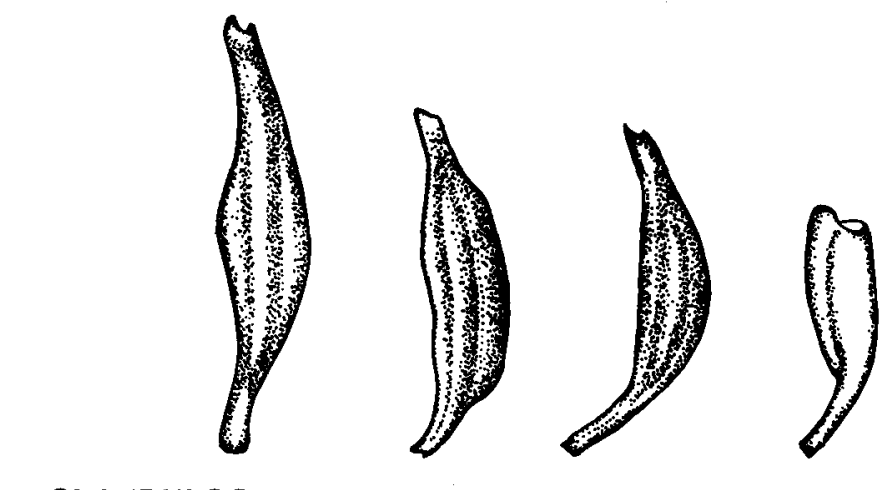

T.GLANDULOSA T.THYMIFOLIA T.PILOSA
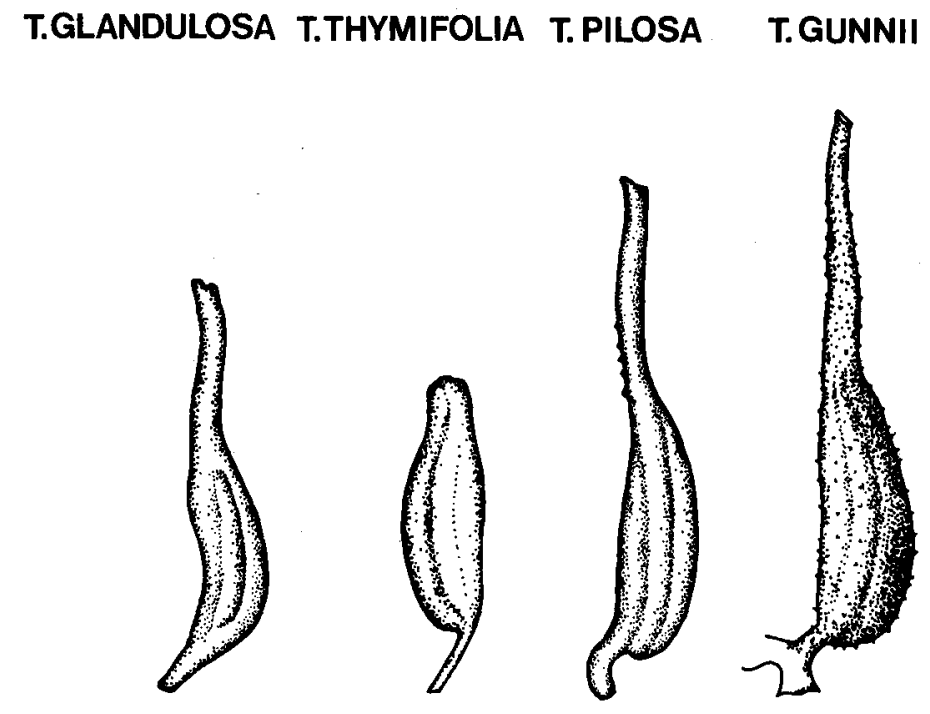

T.CONFERTIFOLIA T. PILIFERA T.VIRGATA T.HIRSUTA

Scale $(\mathrm{mm})$ 
The number of ovules is normally consistent for each species. $T$. affinis has 8 or 10 ovules in each of its 2 loculi but all other species have either 1 or 2 . In New South Wales where, in the Sydney region four superficially similar species are found, a determination of the ovule-number renders identification easy. Dried flowers soaked in detergent soon soften enough for the ovary to be torn with a needle and the ovule-number determined. Without this knowledge, or without previous experience of the species, atypical specimens could be hard to place. The anatropous ovules are pendulous and attached to the central axis at the extreme top or near the centre or, more usually, somewhere in between, see fig. 5 . The axis may be thickened or even project near the point of attachment and often there is a characteristic outgrowth covering this point.

\section{Fig. 5 OVULES AND PLACENTATION}

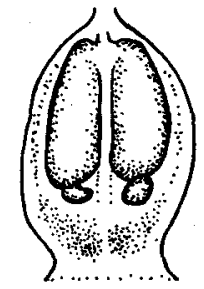

T. HIRSUTA

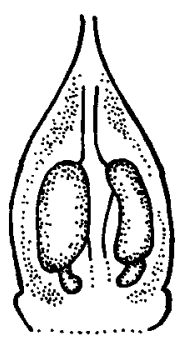

T.ELLIPTICA

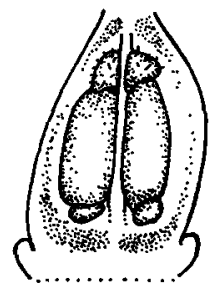

T.SETIGERA

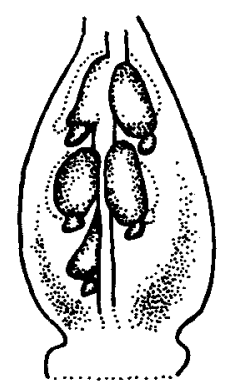

T. AFFINIS

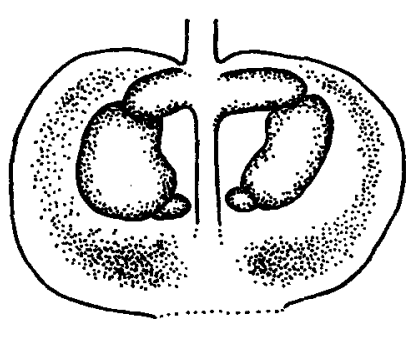

T. DECORA

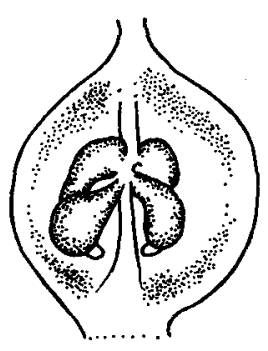

T.THYMIFOLIA

\section{(much enlarged)}

\section{Fruit and seed}

The fruit, where known, is a bilocular capsule $0.5 \mathrm{~cm}$ to $1 \mathrm{~cm}$ long, compressed at right angles to its narrow septum and with its broader side obcuneate to depressedglobular. It dehisces loculicidally and occasionally later at the septum. Some fruits are shortly stalked. Unfortunately many species have never been collected in fruit, probably because plants of Tetratheca are difficult to distinguish from other heath plants when there are no flowers to draw attention to them. 
The seeds are $2 \mathrm{~mm}$ to $4.5 \mathrm{~mm}$ in length, brown and often shining, with very fine appressed to spreading hairs. They are obovoid to cylindrical, tapering obliquely at the base and flattened or concave on the adaxial side occasionally with a trace of tissue which may be analogous to the raphe in Comesperma (Polygalaceae). The apex, the distal end, is rather truncate and bears a cream-coloured appendage which is twisted, usually in several coils, above or beside the seed towards the axis. The appendage usually bears sparse fine spreading hairs but is glabrous in $T$. ericifolia. Seeds could be useful for classification and identification but $I$ have seen mature seeds of only 20 of the 39 species.

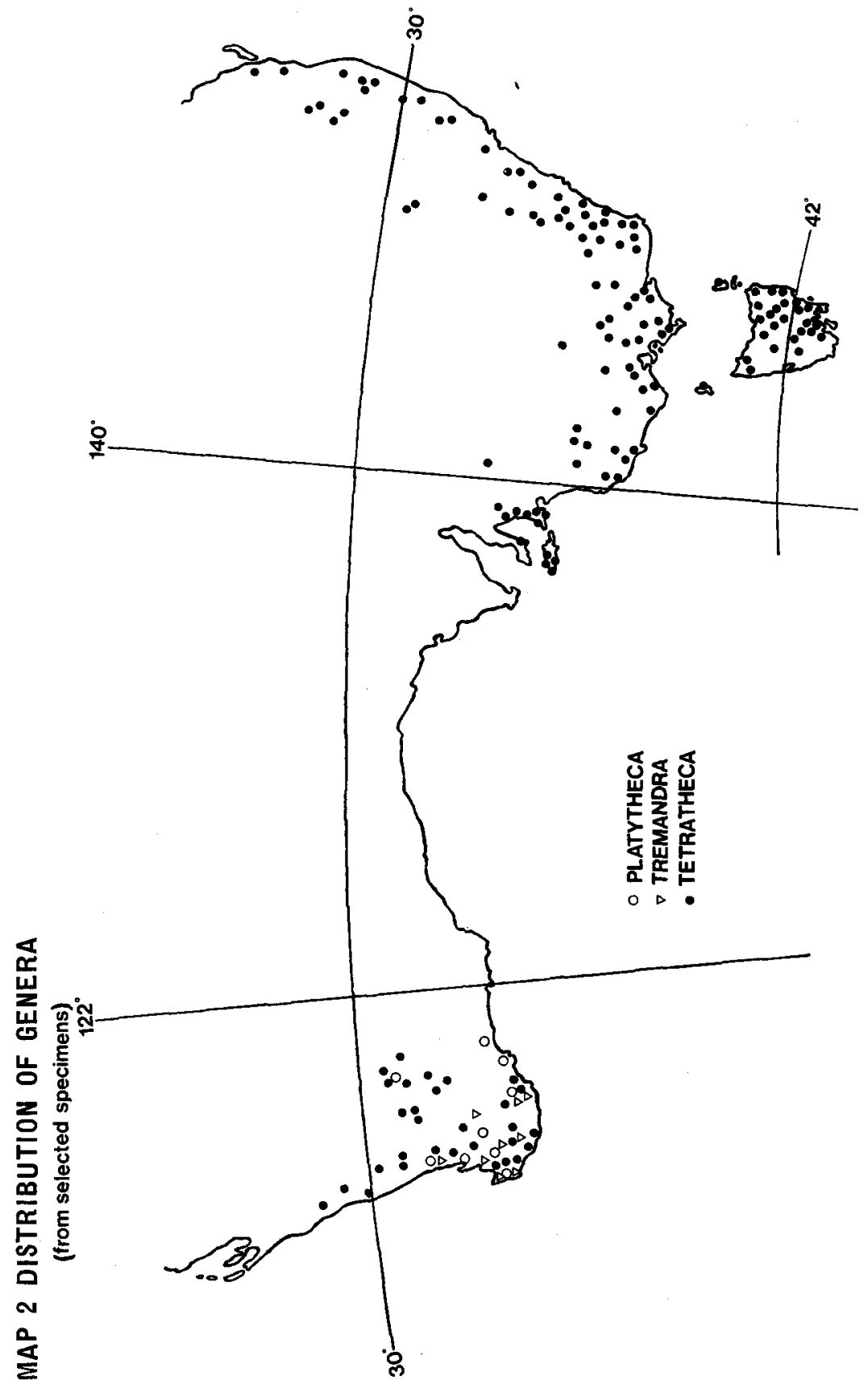


TETRATHECA Sm.

Tetratheca Sm., Specimen Bot. New Holland: 5, t. 2 (1793); R. Brown in Flinders, Voy. Terra Australis 2: 544 (1814); J. E. Smith in Rees Cycl. 35 (2):(1817); Candolle, Prodr. 1: 343 (1824); Steetz in Lehmann, Pl. Preiss. 1: 211 (1845); Payer in Annales des Sci. Nat. Bot. [Ser. 3] 15: 351 (1851); Steetz, Familie Tremandreen: 11 (1853); Schuchardt, Syn. Tremandr.: 18 (1853); F. Mueller, Pl. Indig. Colony Victoria 1: 183 (1860-62); Bentham, Fl. Austral. 1: 132 (1863); Baillon, Histoire des Plantes 5: 67 (1874); Diels \& Pritzel in Bot. Jahrb. Syst. 35: 326 (1904).

TYPE SPECIES: Tetratheca juncea $\mathrm{Sm}$.

Perennial shrubs to $1.5 \mathrm{~m}$ in height though often $20 \mathrm{~cm}$ or less, compact with erect or ascending stems or diffuse with weak procumbent or prostrate stems, usually with numerous stems arising from a woody, often rhizomatous stock; stock and/or the lower part of the stems much-branched. Stems terete, somewhat ridged or quadrangular, or winged, rarely glabrous, usually pubescent with hairs of more than one kind and often bearing tubercles, the stem often terminating in a stiffened point, the branching alternate, opposite or irregularly verticillate, often infrequent, with the branches erect or less frequently spreading. Leaves alternate, opposite or verticillate with up to 6 leaves in the whorl, linear to orbicular, usually less than $2 \mathrm{~cm}$ in length, the margins flat to revolute, usually entire but occasionally with several lobes, the apex obtuse to pungent-pointed and usually incurved, the upper surface glabrous or pubescent and often bearing large tubercles, the lower usually paler and less pubescent than the upper, the petiole short, occasionally bearing stipule-like setae, or absent; in a number of species most leaves are reduced to scales or are readily deciduous. Flowers usually occurring singly, occasionally several together, in the axils of upper, often modified, leaves and usually subtended by minute bracts. Peduncles often dark-coloured, often lengthening to more than $3 \mathrm{~cm}$ as the flower matures, glabrous or pubescent with hairs of one or more kinds and in some species with minute shining spots, usually slender and expanding widely in the extreme upper part to a receptacle from less than $1 \mathrm{~mm}$ to more than $3 \mathrm{~mm}$ in width. Calyx consisting of 4 or 5, usually unconnected, segments placed around the rim of the receptacle usually with the lower outer surface of each lying back over the incurved rim and often thickened, deciduous, occasionally the segments continuous with the receptacle and persistent, the segments usually dark-coloured and in general ovate though varying with the species, obtuse to long-acuminate, glabrous or with a pubescence of one or more kinds of hair, occasionally with minute shining spots, the inner surface usually with fine curled hairs, especially inside the margin. Petals 4 or 5, alternating with the calyx-segments, and each in the bud longitudinally folded on each side to enclose two stamens, usually a deep lilac-pink colour but occasionally paler pink, white or purple, and often very dark at the base, from less than $5 \mathrm{~mm}$ to more than $2 \mathrm{~cm}$ in length and somewhat variable within the species, usually linguiform but often obovate to ovate, usually readily deciduous, occasionally tardily deciduous or persistent. Stamens twice the number of petals with two stamens in front of each petal, free or tending to be joined at the base in pairs, the filaments varying in length and shape with the species, often merging with the base of the anther, the anthers basifixed, 4-locular with two narrow loculi arranged in front of a broader outer pair, terminating in a single, often oblique and usually 2-lipped orifice usually at the end of a short or long anther-tube. Ovary 2-locular, glabrous or wholly or partly pubescent with one or more kinds of hair, often on a stout base and at the top rounded or tapering, rarely emarginate, below a filiform style. Ovules 1 or 2 , rarely several, in each loculus, anatropous, pendulous from the upper or occasionally middle part of the central axis. Fruit a variously compressed capsule to $\mathrm{c}$. $1 \mathrm{~cm}$ in length, narrowly elliptical to compressed-orbicular in shape, opening at the margins and occasionally also but later at the septum. Seeds $2-4.5 \mathrm{~mm}$ long, obovoid to cylindrical, brown and smooth, with fine hairs, and at the apex truncate and bearing a cream-coloured, adaxially coiled appendage.

A genus of 39 species endemic in the southern half of the Australian continent. The name is derived from the Greek words tetra, four, and theca, cases, i.e. the four anther-loculi.

G $13570-29$ 


\section{KEY TO THE SPECIES}

1. Flowers 5-merous or if 4-merous the anther-tube more than $\frac{1}{2}$ as long as the body of the anther or if shorter then the flowers purple. W.A. or S.A. (Kangaroo I).

2. Plants with a generally leafless aspect, though some leaves may be present.

3. Stems winged

T. affinis 1.

3.* Stems not winged.

4. Stamens with filaments less than $\mathbf{0 . 2 5} \mathrm{mm}$ long and anther-tubes less than $1 \mathrm{~mm}$ long.

5. Stems stout, $1.1-1.8 \mathrm{~mm}$ broad in the flowering region. Stamens more than $3 \mathrm{~mm}$ long. S.A. (Kangaroo I) ........... T. halmaturina 7.

5.* Stems slender, $0.5-0.8 \mathrm{~mm}$ broad in the flowering region. Stamens $3 \mathrm{~mm}$ or less in length. W.A. .......................

4.* Stamens otherwise.

6. Receptacle of the flower more than $1.5 \mathrm{~mm}$ in width.

7. Base of the plant covered with strongly retrorse setae. Filaments

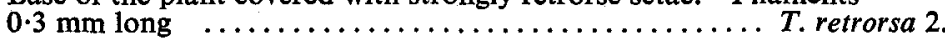

7.* Base of the plant not covered with strongly retrorse setae. Filaments $1 \mathrm{~mm}$ long and very broad $\ldots \ldots \ldots \ldots \ldots \ldots$, . efoliata 3.

6.* Receptacle of the flower $1-1.5 \mathrm{~mm}$ wide.

8. Peduncles densely pubescent, less than $5 \mathrm{~mm}$ in length.

9. Stems stout, $2 \cdot 3 \mathrm{~mm}$ broad in the flowering region. Body of the anther $3.5 \mathrm{~mm}$ long $\ldots \ldots \ldots \ldots \ldots \ldots \ldots$. aphylla 4.

9.* Stems relatively slender, $0.8-0.9 \mathrm{~mm}$ broad in the flowering region. Body of the anther $2 \mathrm{~mm}$ long $\ldots \ldots . T$. paucifolia 5.

8.* Peduncles glabrous, $5 \mathrm{~mm}$ or more in length.

10. Stems slender, $0 \cdot 3-1 \cdot 1 \mathrm{~mm}$ broad in the flowering region.

11. Leaf-blades tapering at the base. Filaments stout, c. 1 mm long $\ldots \ldots \ldots \ldots \ldots \ldots \ldots \ldots \ldots \ldots \ldots \ldots \ldots \ldots \ldots$. virgata 14.

11.* Leaf-blades broad at the base. Filaments slender, c. 0.5 mm long $\ldots \ldots \ldots \ldots \ldots \ldots \ldots \ldots \ldots . \ldots \ldots$. remota 15.

10.* Stems stout, $1 \cdot 1-1 \cdot 8 \mathrm{~mm}$ broad in the flowering region.

12. Stems densely covered with stout tubercle-based setae.

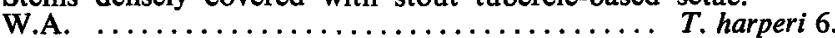

12.* Stems almost glabrous. S.A. (Kangaroo I) .. T. halmaturina 7.

2.* Plants leafy.

13. Flowers purple. Stamens with very slender filaments $1 \mathrm{~mm}$ long, the anthers yellow, occasionally flushed with purple, and with a short tube with a broad

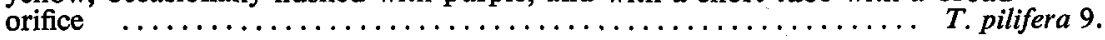

13.* Flowers dark pink, or occasionally white. Stamens not as above.

14. Anther-tube very long, usually dark-coloured, covered with minute tubercles and with a very narrow orifice.

15. Stems with curled or irregular white hairs or without white hairs, rarely with straight white hairs but then the leaves more than $1 \mathrm{~cm}$

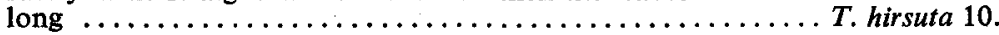

15.* Stems with numerous straight white hairs; leaves rarely more than $1 \mathrm{~cm}$ long, the majority much shorter $\ldots \ldots \ldots \ldots \ldots . . . .$. . hispidissima 11.

14.* Anther-tube not as above.

16. Flowers 4-merous or if 5 -merous then the filaments $1 \mathrm{~mm}$ long.

17. Leaves in whorls of $3 \ldots \ldots \ldots \ldots \ldots \ldots \ldots \ldots$, similis 12.

17.* Leaves alternate.

18. Leaves pubescent. Stamens $3 \mathrm{~mm}$ long ........ f. fasciculata 13 .

18.* Leaves glabrous or almost so. Stamens $4.5 \mathrm{~mm}$ or more in length $\ldots \ldots \ldots \ldots \ldots \ldots \ldots \ldots \ldots \ldots \ldots \ldots \ldots \ldots \ldots \ldots$. virgata 14.

16.* Flowers 5-merous. Filaments less than $1 \mathrm{~mm}$ in length.

19. Leaf-blades broad at the base and glabrous or with few hairs, smooth.

20. Anther-tube $1 \cdot 5-2 \mathrm{~mm}$ long. Filament slender ..... T. remota 15 . 20.* Anther-tube $0.5 \mathrm{~mm}$ long. Filament absent ..... T. deltoidea 16 .

19.* Leaf-blades narrow at the base or if broad then pubescent or densely tuberculate.

21. Peduncles less than $2 \mathrm{~cm}$ in length. Calyx-segments thickened near the base. 
22. Petals less than $8 \mathrm{~mm}$ in length. Calyx-segments $1.5 \mathrm{~mm}$ long and bearing scattered stout setae .......T. parvifolia 17.

22.* Petals $8 \mathrm{~mm}$ or more in length. Calyx-segments $2 \mathrm{~mm}$ or more in length, or if less then glabrous.

23. Leaves broadly ovate and usually with 2-4 lobes, often in whorls of $3 \ldots \ldots \ldots \ldots \ldots \ldots \ldots$. pubescens 18 .

23.* Leaves elliptical to linear, alternate.

24. Stamens $3 \mathrm{~mm}$ long. Peduncles $6 \mathrm{~mm}$ or less in length $\ldots \ldots \ldots \ldots \ldots \ldots \ldots \ldots$ T. elliptica 19.

24. Stamens 3.5-4 mm long. Peduncles usually more than $6 \mathrm{~mm}$ in length.

25. Stems glabrous in the upper part and with strongly retrorse setae in the lower part. Receptacle of the flower $2-2.5 \mathrm{~mm}$ broad $\ldots \ldots \ldots \ldots \ldots \ldots \ldots \ldots \ldots \ldots \ldots$. retrorsa 2.

25.* Stems usually covered with spreading setae. Receptacle of the flower $1.5 \mathrm{~mm}$ broad $\ldots \ldots \ldots \ldots \ldots \ldots \ldots \ldots . \ldots \ldots$. setigera 20.

21.* Peduncles usually more than $2 \mathrm{~cm}$ in length. Calyxsegments not conspicuously thickened at the base.

26. Leaves alternate or irregularly opposite, conspicuously pubescent. .................... confertifolia 21 .

26.* Leaves in whorls of 3, with sparse hairs ..... T. filiformis 22 .

1.* Flowers 4-merous. Anther-tube less than $\frac{1}{2}$ as long as the body of the anther or if longer then the base of the calyx-segments attached at the edge of the receptacle. Q., N.S.W., Vic., S.A., Tas.

27. Stems winged

T. juncea 23.

27.* Stems not winged.

28. Plant dimorphic; some branches glabrous with linear leaves, some with dense stout antrorse hairs and broad-elliptical to almost orbicular leaves .. T. shiressii 24. 28.* Plant not dimorphic.

29. Stems almost completely leafles

T. subaphylla 25.

29.* Stems leafy at least on the lower part.

30. Calyx-segments persistent or tardily deciduous, with no joint at their junction with the receptacle.

31. Leaves usually linear with revolute margins. Stem-hairs rarely

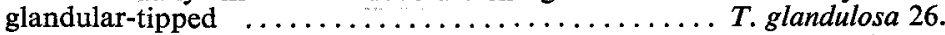

31.* Leaves rarely linear, usually oblanceolate to broadly obovate. Stem-hairs usually glandular-tipped .......... T. labillardierei 27.

30. Calyx-segments readily deciduous at their junction with the receptacle.

32. Ovules 4 , with 2 in each loculus.

33. Peduncles with at least a few, usually many, glandular-tipped hairs or setae. Calyx-segments usually conspicuously reflexed:

34. Peduncles bearing glandular-tipped setae $1-2 \mathrm{~mm}$ long. Stems glabrous or with minute straight hairs .. T. stenocarpa 28.

34.* Peduncles bearing glandular hairs usually less than $1 \mathrm{~mm}$ in length. Stems with hairs of varying lengths .. T. ciliata 29.

33.* Peduncles without glandular-tipped hairs or setae. Calyxsegments not conspicuously reflexed.

35. Stem-hairs stout, c. $\mathbf{0} \cdot 5 \mathrm{~mm}$ long and regularly antrorse. Leaves linear, the apex obtuse but often with a minute point $\ldots \ldots \ldots \ldots \ldots \ldots \ldots \ldots \ldots \ldots \ldots \ldots \ldots \ldots \ldots \ldots$ ericifolia 30.

35.* Stem-hairs not as above. Leaves linear to almost orbicular but if linear then the apex rather acute and pungent.

36. Most stem-hairs $<0.5 \mathrm{~mm}$ long, curved or curled. Lower part of the calyx-segments scarcely thickened

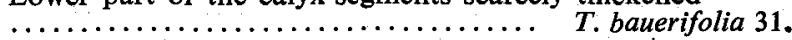

36.* Most stem-hairs $0.5-1.5 \mathrm{~mm}$ long, tending to be antrorse but many twisted and irregular, rarely absent. Lower part of calyx-segments thickened.

37. Leaves linear with closely revolute margins ........................ T. rupicola 32. 
37.* Leaves narrowly elliptical to almost orbicular, the margins not, or only loosely, revolute......

$\ldots \ldots \ldots \ldots \ldots \ldots \ldots \ldots \ldots \ldots \ldots \ldots \ldots$ T. thymifolia 33.

32.* Ovules 2, with 1 in each loculus.

38. Stem-hairs stout, c. $0.75 \mathrm{~mm}$ long and regularly antrorse. Filament $1 \cdot 25-2 \cdot 25 \mathrm{~mm}$ long with the body of the anther rather abruptly expanding above it $\ldots \ldots \ldots \ldots . T$. decora 34.

38. Stem-hairs not as above. Filament less than $0.75 \mathrm{~mm}$ in length, gradually expanding into the body.

39. Stamens with the apex much expanded and terminating in a large orifice, the anther-tube absent .......T. gunnii 35 .

39.* Stamens with a distinct, though often short, anther-tube.

40. Most stem-hairs short and conspicuously retrorse... ............................. T. rubioides 36.

40.* Stem-hairs usually both short and long but if mostly short then not conspicuously retrorse.

41. Leaves in strict whorls of 4-6 and usually less than $1 \mathrm{~mm}$ in width ........... neglecta 37.

41.* Leaves alternate, opposite or in irregular whorls of 3,4 or rarely 5 , usually more than $1 \mathrm{~mm}$ width.

42. Peduncles $1 \mathrm{~cm}$ or more in length in the mature flower and much longer than the leaves $\quad \ldots \ldots \ldots \ldots \ldots \ldots \ldots$. insularis 38

42.* Peduncles less than $1 \mathrm{~cm}$ in length and never much longer than the leaves ..T. pilosa 39.

1. Tetratheca affinis Endl. in Huegel, Enum. Pl.: 7 (1837); Steudel, Nomencl. Bot. [ed. 2] 2: 673 (1841); Walpers, Repert. Bot. Syst. 1: 249 (1842); Steetz in Lehmann, Pl. Preiss. 1: 211 (1845); Walpers, Repert. Bot. Syst. 5: 68 (1845); A. Gray in Hooker's J. Bot. Kew Gard. Misc. 4: 200 (1852); Steetz, Familie Tremandreen: 12 (1853); Schuchardt, Syn. Tremandr.: 19 (1853); Bentham, Fl. Austral. 1: 132 (1863); F. Mueller, Fragm. 12: 5 (1882); F. Mueller, Syst. Census Austral. P1. 1: 9 (1882); F. Mueller, Second Syst. Census 1: 15 (1889); Diels \& Pritzel in Bot. Jahrb. Syst. 35: 330 (1904); Gardner, Enum. PI. Austral. Occ.: 71 (1930); Blackall \& Grieve, Western Austral. Wildflowers 1: 260 (1954); Beard, W. Austral. P1.: 56 (1965).

HoLOTYPE: King Georges Sound [Western Australia], (Hügel), not examined. The specimen from Gordon R, Oldfield (MEL 1007594), was examined and cited by Bentham, who also cited and probably saw Huegel's specimen from King Georges Sound. I have examined this specimen and also the Preiss specimen, 1334 (MEL 1007585), which was compared (as noted on the sheet) with Huegel's specimen by Steetz.

SYNONYMY: Tetratheca affinis var. platycaula Benth., Fl. Austral. 1: 133 (1863); Diels \& Pritzel in Bot. Jahrb. Syst. 35:330 (1904). SyNTYPES: Drummond 115, 1843; Blackwood \& Stirling Ranges, Oldfield. Of these I have seen only Ironstone Hills, Blackwood, Western Australia, Oldfield 197 (MEL 1007606), a specimen seen by Bentham.

Tetratheca platycaula (Benth.) Ostenfeld in Dansk. Viden. Selsk. Biol. Medd. 3: 82 (1921). TYPE: As for Tetratheca affinis var. platycaula.

A leafless shrub with stems to $60 \mathrm{~cm}$ in length from a branched, woody, perhaps rhizomatous stock; stems with some branching near the stock but little above this. Stems with 2 wings each usually $1-5 \mathrm{~mm}$ broad but contracting near the base where the stems are usually 4-ridged, glabrous except for very occasional white hairs or, at the base, areas of either short, stiff, erect or even slightly retrorse hairs or scattered setae; the branching alternate, usually, but not always, at an acute angle. Leaves alternate, oblanceolate, sparsely toothed, but usually all reduced to somewhat keeled, acute, deltoid scales 1-3 mm long. Flowers occurring among clusters of reduced leaves in the axils of reduced leaves with bracts hidden in the cluster. Peduncles light-coloured, 5-12 mm long, glabrous or with scattered, glandular-tipped, short setae or with minute, fine, erect hairs; broadening and angled in the upper part to form a conical receptacle $1.5-3 \mathrm{~mm}$ in diameter. Calyx-segments 4 or 5 , deciduous, 2.5-3.0 mm long, ovate or almost deltoid, acuminate to long-acuminate, glabrous 
or rarely with occasional glandular hairs on the margin with hairs near the margin and apex of the inner surface, the base of each segment attached well inside the margin of the receptacle but erect and unthickened. Petals 4 or 5, dark pink, often appearing pale or white in the bud, at least in dried specimens, obovate to broadly linguiform, $7-15 \mathrm{~mm}$ long and usually a little more than $\frac{1}{2}$ as wide with the greatest width in the upper $\frac{1}{2}$, deciduous. Stamens usually 10 , occasionally less, $5.5 \mathrm{~mm}$ or more in length; filament broad, $1 \mathrm{~mm}$ or less in length; body of the anther $3 \mathrm{~mm}$ long, somewhat flattened and curved at the base with the main part slightly curved, almost black, shining, usually bearing coarse hairs and abruptly contracted into the anthertube; anther-tube narrow, curved, red, c. $2 \mathrm{~mm}$ long with an almost straight orifice. Ovary with sparse glandular hairs; on a short broad base and tapering at the apex to a slender and often twisted style $4 \mathrm{~mm}$ long. Ovules 8 or 10,4 or 5 in each loculus, usually limited to the top half of a double central axis (fig. 5). Fruit broadly elliptical, ovoid to almost orbicular, usually with a short slender point; somewhat flattened, especially at the margins, $7-10 \mathrm{~mm}$ long and $\frac{2}{3}$ as wide, the axis not widening at the placenta. Seeds seen only in an immature condition, then $3.5 \mathrm{~mm}$ long, brown, cylindrical, tapering at the base and with rather dense retrorse hairs, the appendage dark cream, twisting towards the axis and with minute spreading hairs.

Distribution: In sandy or lateritic soil in open heath and sclerophyll forest in SW. Western Australia: Map 3, see p. 159.

Specimens Examined (Selection Only): Western Australia: Warren District and the Stirling Range area: Yallingup, Ostenfeld 10.1914 (PERTH); Balingup, Pulleine NSW 125082, 12.1917 (NSW); near Hester Siding, Burbidge 2559, 9.1947 (CANB); Upper Blackwood R, Mueller 12.1877 (MEL); 5-6 miles [c. 8-9 km] from Bridgetown, Ashby 500, 9.1963 (AD); Bridgetown, Maiden NSW 125071, 10.1909 (NSW); Jardanup, Koch 2352, 10.1918 (BRI, NSW, PERTH), Jardanup, S. of Bridgetown, Ostenfeld 1092, 10.1914 (AD, MEL, NSW, PERTH); Tone R Valley along track to Mordalup from Muirs Highway, about 45 miles [72 km] SE. of Boyup Brook, Belcher 403, 10.1967 (MEL, PERTH); Blackwood, Oldfield 197 (MEL 1007606); Blackwood R, District Nelson, Pritzel 534, 8.1901 (AD, NSW, PERTH); 1 mile [1.6 km] S. of Manjimup, Aplin 1460, 12.1961 (PERTH); Nornalup-Mamjimup association, Aplin 2193, 10.1962 (PERTH); Lake Muir, Muir (MEL); Gardiner R (MEL); Gordon R, Oldfield 197c (MEL 1007594); Tenterden, Morrison 9.1902 (PERTH); 15 miles [24 km] W. of Chester Pass on road to Red Gum Pass, Stirling Ranges, Muir 3907, 9.1966 (MEL); Stirling Range, $25 \mathrm{~km}$ W. of Chester Pass on E.-W. road to Red Gum Pass, Wilson 4214, 9.1966 (NSW, PERTH); near Chester Pass, Stirling Ranges, Phillips 10.1962 (CBG 010001); Salt Lakes, foot of Stirling Range, Maxwell 39 (MEL); grassy ridges on the sources of the Kalgan (MEL); c. $3 \mathrm{~km} \mathrm{~N}$. of Mt Barker Eichler 15967, 8.1959 (AD); Mt Barker, Fitzgerald NSW 125083, 11.1907 (NSW); Mt Barker, Porongerup road, Rogerson 59, 10.1965 (PERTH); swamp c. $8 \mathrm{~km} \mathrm{S.} \mathrm{of} \mathrm{Mt} \mathrm{Barker,} \mathrm{Eichler}$ 15997, 9.1959 (AD); Porongerup, Mueller 1867 (MEL); Porongerups, Cashmore 76, 9.1939 (PERTH); 25 miles [40 km] N. of Albany, lower hills of Porongerup Range, Turner 5505, 9.1965 (PERTH); Upper Hay R, Warburton 1873 (MEL); "Monliup", 25 miles [40 km] E. of Albany, Elder NSW 125075, 10.1931 (NSW); Mt Melville, 10.1867 (MEL); in subarenosis sylvae prope urbiculam Albany, Preiss 1334, 9.1840 (MEL 1007585); Albany, Andrews 12.1902 (NSW 125081, PERTH); Albany, Ostenfeld 1096, 10.1914 (PERTH); King Georges Sound, Goadby 174 (NSW); King Georges Sound, Goadby 114, 9.1898 (PERTH); King Georges Sound, herb. Sonder (MEL); King Georges Sound, Brown (MEL).

This species differs from all others in its numerous ovules. Its closest affinities are with $T$. efoliata and $T$. retrorsa which each have 4 ovules. It is the only Western Australian species with winged stems. The Eastern Australian T. juncea, which also has winged stems, is not closely related.

\section{Tetratheca retrorsa $J$. Thompson sp. nov.}

Holotype: Reserve-17 miles [28 km] East of Pingelly [Western Australia], T. E. H. Aplin 824, 10.1960 (PERTH).

Fruticulus usque ad $1.5 \mathrm{~m}$ altus. Rami glabri vel setis longis retrorsis vestiti. Folia alterna, usque ad fere $20 \mathrm{~mm}$ longa, anguste elliptica, saepe reducta vel decidua. Pedunculi 7-16 mm longi; receptaculo 2-2.5 mm diametro. Flores 5-meri. Stamina filamentis $0.3 \mathrm{~mm}$ longis; tubis antherarum tenuibus valde curvis, $1.5 \mathrm{~mm}$ longis. Ovarium glabrum; ovulis 4. 
A sparsely-leaved spreading shrub to $1.5 \mathrm{~m}$ in height, the stems branching in the upper part, the stock, from the fragment seen, apparently slender. Stems variable in width, the older stout, the younger slender; terete, often rather grey-green, some glabrous, others with retrorse, appressed, brown, tubercle-based setae $1.5 \mathrm{~mm}$ long, the lower stems with the setae dense, dark-reddish-coloured, over $2 \mathrm{~mm}$ long and although strongly retrorse not appressed (fig. 1), the stems ending in a point, stiff on older growth, and $0.8-2.5 \mathrm{~mm}$ broad in the flowering region, the branching alternate and usually at an acute angle. Leaves alternate, up to almost $20 \mathrm{~mm}$ in length, narrowly elliptical but often appearing linear owing to the revolute margins, glabrous or with a few stiff hairs near the acute apex, the petiole conspicuous; usually found only on new shoots, on older branches the leaves reduced or deciduous above the remains of the petiole. Flowers occurring singly in the axils of leaves or their bases, with one or several bracts up to $1 \mathrm{~mm}$ in length, the bracts dark brown, linear and with a few hairs usually near the tip. Peduncles $7-16 \mathrm{~mm}$ long, pale-coloured, glabrous or with a few minute hairs; widening and angled in the upper part and again in the extreme upper part to form a receptacle $2-2.5 \mathrm{~mm}$ in diameter. Calyxsegments 5 , deciduous, $1.5-3 \mathrm{~mm}$ long, broadly ovate, rather obtuse with a very short point, glabrous except on the inner surface which has a fringe of hairs, the base of each segment attached well inside the top of the receptacle and folded back over it. with a thick ridge across the back above the edge of the receptacle, Petals 5 , dark pink, obovate, $8-11 \mathrm{~mm}$ long and c. $\frac{1}{2}$ as wide with the greatest widith in the top $\frac{1}{2}$, deciduous. Stamens usually $10,3.5-5 \mathrm{~mm}$ long; filament $0.3 \mathrm{~mm}$ long, flat; body of the anther $1.5 \mathrm{~mm}$ long, expanding abruptly above the filament especially at the back, very much curved, with some short stiff hairs and contracting to the anther-tube; the anther-tube slender and very curved, 1.5-2 $\mathrm{mm}$ long, with a broad or narrow and only somewhat oblique orifice. Ovary glabrous, on a broad base; the top rounded and the slender style almost $3 \mathrm{~mm}$ long. Ovules 4, 2 in each loculus, attached near the centre of the axis. Fruit broadly obovate to cuneate, turgid at least in the centre, 8-9 mm long, very shortly stalked. Seeds $4 \mathrm{~mm}$ long, obovoid with a small point at the base and a few hairs at the apex, the adaxial surface not seen, the appendage dark, coiled towards the axis but beyond the seed, with scattered, fine spreading hairs.

Distribution: On laterite "break-away" country in the Wongan Hills and E. of Pingelly, SW. Western Australia. Map 3, see p. 159.

Specimens Examined: Westers Australia: Avon District: Wongan Hills, Morrison 10.1903 (BRI, PERTH); Monks Well Gully, S. end of Wongan Hills, Kenneally 22859.1974 (NSW); Tutanning Reserve, 17 miles [28 km] E. of Pingelly, Royce 7635, 9.1962 (PERTH); reserve 17 miles [28 km] E. of Pingelly, Aplin 824, 10.1960 (PERTH); c. 17 miles [28 km] E. of Pingelly on Tutanning 'as Katanning' Reserve, Parratt 1594, 11.1965 (PERTH).

This species bears some relationship, to $T$. affinis and $T$. efoliata, all three taxa having more than 2 ovules and very broad receptacles. It is closest to $T$. efoliata which also has 4 ovules and whose stamens though differing in dimensions are of simliar shape. There is a similarity to $T$. virgata which probably indicates a relationship but this species can be distinguished by its slender stems, long, broad filaments and 2 ovules.

3. Tetratheca efoliata F. Muell., Fragm. 10:3 (1876); F. Mueller, Fragm. 12: 5 (1882); F. Mueller, Syst. Census Austral. P1. 1: 9 (1882); F. Mueller, Second Syst. Census 1: 15 (1889); Diels \& Pritzel in Bot. Jahrb. Syst. 35: 330 (1904); Gardner, Enum. Pl. Austral. Occ.: 71 (1930); Blackall \& Grieve, Western Austral. Wildflowers 1 : 260 (1954); Beard, W. Austral. Pl.: 56 (1965).

HoLotype: Between Ulering and Mt. Jackson [Western Australia] (MEL 1007793), cited as 'Inter oasim Ularing et montem Jacksoni; Young'. Two other sheet, 17-20 Oct. 1875 (MEL 1007794 ) and MEL 1007795 are probably fragments from the Holotypes. 


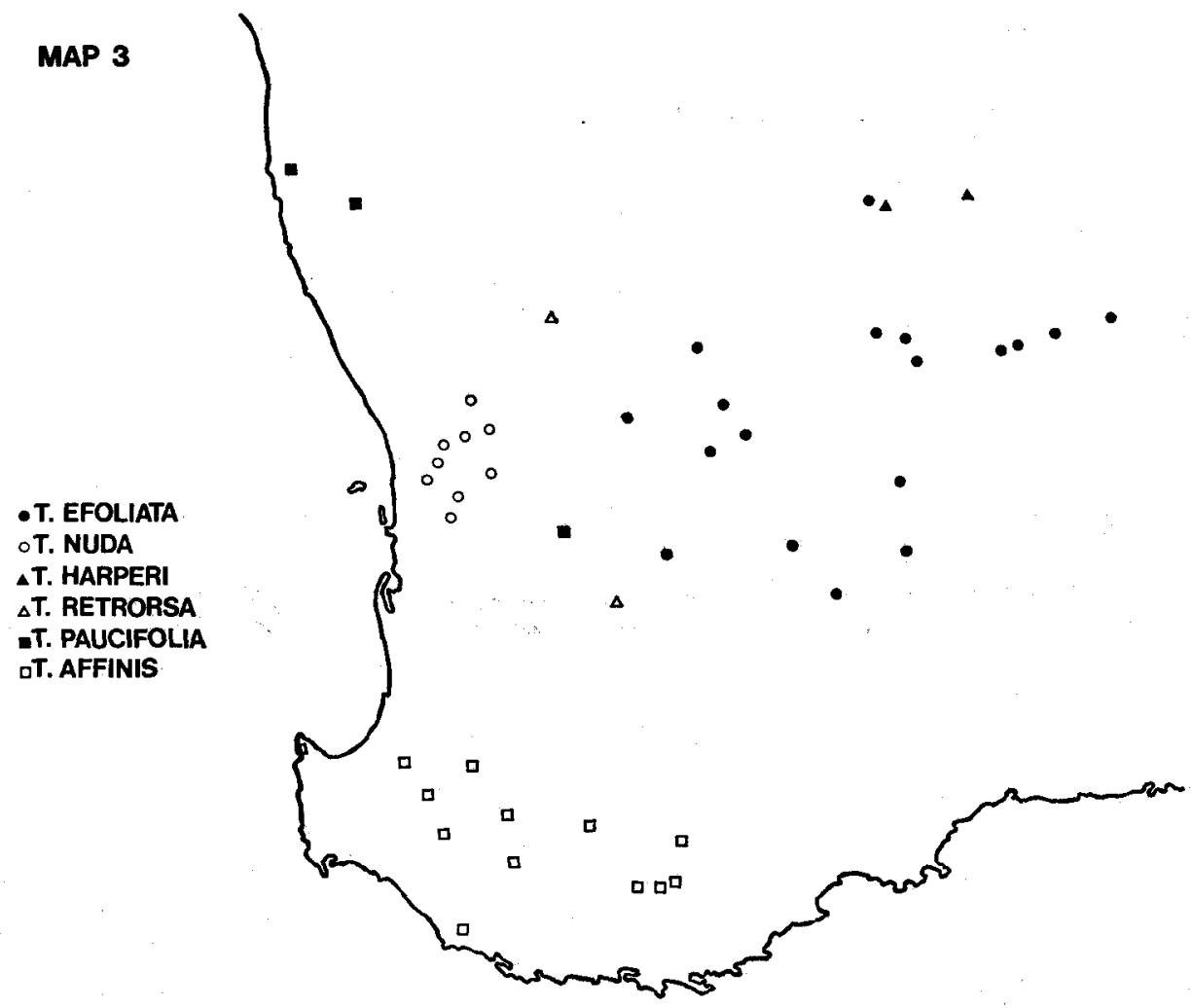

A small relatively leafless shrub with tangled branches, usually 15 to $30 \mathrm{~cm}$ in height, the stock stout woody and branched, the stems branching both near the base and above. Stems stout, terete, rather glaucous, often almost glabrous but usually with some scattered, very short and stout, tubercle-based hairs (these usually with a glandular tip and often bearing lateral hairs), many tubercles and occasionally areas of fine, white, often recurved hairs above the nodes (especially on younger growth), the stems changing direction a little at each node on the main branches so as to appear flexuose or even zigzag, $0.9-1.6 \mathrm{~mm}$ broad in the flowering region, the apex tapering to a hard blackened point, the branching alternate and in the upper part at an acute angle. Leaves alternate, usually $8 \mathrm{~mm}$ or less in length, often very much reduced, elliptical, the blunt tip incurved, the margins revolute, the upper surface with scattered hairs, the blade very deciduous leaving the very broad petiole which often bears tubercles or short, stout setae. Flowers occurring among clusters of leaves in the axils of leaves or leaf-bases with bracts hidden in the cluster. Peduncles darkcoloured, 3-10 $\mathrm{mm}$ long, glabrous, ridged, greatly expanded and angled in the upper part and expanded again in the extreme upper part to form a receptacle c. $2 \mathrm{~mm}$ in diameter; often twisted in the lower part. Calyx-segments 5, or occasionally 4, deciduous, often rather pale, glabrous except for fine hairs near the margin of the inner surface, $4 \mathrm{~mm}$ long, narrowly to broadly ovate, acute to acuminate, each attached inside the top of the receptacle but not thickened at the base. Petals 5 or, less frequently, 4, dark pink, occasionally white, ovate to obovate, 10-18 mm long and c. $\frac{1}{2}$ as wide with the greatest width above or below the centre, deciduous. Stamens usually 10, c. $6 \mathrm{~mm}$ long; filament very stout, almost $1 \mathrm{~mm}$ broad and $1 \mathrm{~mm}$ or more in length; body of the anther rather abruptly expanding, especially dorsally, above the filament, curved, usually red, $2 \cdot 5-3 \mathrm{~mm}$ long, shining and minutely scabrid or smooth and abruptly contracted to the anther-tube; anther-tube curved, red or 
yellow, 2.5-3 mm long with a conspicuously 2-lipped orifice. Ovary with scattered glandular hairs; more or less expanded at the base to form a stout stalk to the young fruit and with a slender style more than $4 \mathrm{~mm}$ long. Ovules 4,2 in each loculus, attached to the upper part of the central axis. Fruit obovate to obcordate, glabrous or with scattered glandular hairs, somewhat flattened, $8-9 \mathrm{~mm}$ long and c. $\frac{2}{3}$ as wide, the axis broader near the placenta. Seeds $4.5 \mathrm{~mm}$ long, shortly cylindrical, tapering at the base, truncate at the apex and a little flattened on the adaxial side, dark brown with fine dense spreading or somewhat spreading hairs, the appendage dark cream with c. 3 loose coils along the adaxial side or beyond, with numerous fine spreading hairs.

Distribution: On sandplain and in sandy heath in SW. Western Australia. Map 3, see page 159.

Specimens Examined: Western Australia: Avon District: Waddouring, Alexander 10.1915 (PERTH); Merredin, Koch 2935, 11.1923, (MEL, NSW); Tammin, Salisbury 8.1949 (PERTH); 5 miles [8 km] N. of Tandagin, Bailey 326, 10.1945 (PERTH); Bruce Rock, Wilson \& Herbert 11.1920 (PERTH); sources of the Swan R, Merrall 1888 (MEL); far inland from King Georges Sound, Hassell 1882 (MEL); 13 miles [21 km] NE. of Hyden, Newbey 1095, 10.1965 (PERTH); c. $100 \mathrm{~km}$ W. of Daniell, Kuchel 1806, 9.1964 (AD). Coolgardie District: Between Ulering and Mt Jackson (MEL 1007793); 10.1875 (MEL 1007794); (MEL 1007795); Coolgardie, Kelso 1902 (PERTH); c. 65 km W. of Coolgardie, Kuchel 2155, 9.1964 (AD); Boorabbin, Coolgardie Goldfields, Pritzel 913, 11.1901 (AD, NSW, PERTH); 294 miles [473 km] peg, Great Eastern Highway, Aplin 1925, 9.1962 (PERTH); 1 mile [1.6 km] E. of Boorabbin, Gardner 7991, 10.1945 (PERTH); 52 miles [84 km] W. of Coolgardie, Phillips 9.1962 (CBG 019116 , NSW); 57 miles [92 km] W. of Coolgardie, Briggs NSW 125041, 9.1960 (NSW); 288 mile [457 km] peg, Great Eastern Highway, George 4252, 9.1962 (PERTH); $84 \mathrm{~km}$ E. of Southern Cross, Wilson 7173, 8.1968 (PERTH); c. 40 miles [64 km] E. of Southern Cross, Phillips 9.1968 (CBG 028003, NSW); c. $8 \mathrm{~km}$ E. of Yellawdine, Kuchel 2128, 9.1964 (AD); c. 250 mile [403 km] peg on Great Eastern Highway (AD); $27 \mathrm{~km}$ E. of Southern Cross, Blackall 915, 10.1931 (PERTH); near Southern Cross, Blackall 9.1929 (PERTH); between Bunkin and Southern Cross, Cronin 1893 (MEL); between Upper Blackwood R and Lake Lefroy, Cronin 1893 (MEL $1008400,1008401,1008402$ ); E. of Mt Holland, Gardner 7.1930 (PERTH); 42 miles [67 km] E. of Hyden, Newbey 1132, 10.1963 (PERTH); 47 miles [76 km] E. of Hyden, Lullfitz 3836, 11.1964 (PERTH); 290 mile [467 km] peg, Hyden-Norseman road, Beard 3860, 10.1964 (PERTH).

The affinities of this species are with $T$. affinis and $T$. retrorsa especially the latter which has the same number of ovules and anthers of similar shape notably in the abrupt transition from filament to anther and from anther-body to anther-tube.

4. Tetratheca aphylla $F$. Muell. in S. Science Record 2: 97 (1882); F. Mueller, Fragm. 12: 5 (1882); F. Mueller, Syst. Census Austral. Pl. 1: 9 (1882); F. Mueller, Second Syst. Census 1: 15 (1889); Gardner, Enum. Pl. Austral. Occ.: 71 (1930).

HoLotYPE: Western Australia, J. Drummond (MEL 1008033).

Habit unknown. Stems stout, terete, with slight vertical ridges, covered with dense minute tubercles produced into minute spreading or slightly retrorse hairs especially near the nodes, the stems $2.3 \mathrm{~mm}$ broad in the flowering region, the branches apparently few, alternate. Leaves alternate, soon deciduous. Flowers occurring singly in the axils of leaf-bases with bracts $1 \mathrm{~mm}$ long, lanceolate and with spreading hairs especially on the upper surface. Peduncles $4 \mathrm{~mm}$ long, dark-coloured, with rather dense, minute, stiff hairs and a few, very small, coloured glandular hairs; twisted at the base and widening and somewhat 5-angled above, only a little wider at the top, forming a receptacle a little more than $1 \mathrm{~mm}$ in diameter. Calyx-segments 5 , deciduous, $3 \mathrm{~mm}$ long, narrowly deltoid, acute, dark-coloured, with minute, stiff, spreading hairs and scattered small, broad-based, glandular hairs, the inner surface with hairs especially near the margin and showing from the outside, the base of each segment attached just inside the top of the receptacle, perhaps a little thickened, certainly angled, across the back. Petals 5 , dark pink, obovate to elliptical, c. $1 \mathrm{~cm}$ long and c. $\frac{1}{2}$ as wide with the greatest width apparently near the centre, deciduous. Stamens probably $10,5 \mathrm{~mm}$ long; filament flat, c. $0.5 \mathrm{~mm}$ long, passing almost imperceptibly into the flattened base of the body of the anther; body of the anther 
$3.5 \mathrm{~mm}$ long, the lowest $0.5 \mathrm{~mm}$ or more flattened and then the body slightly angled and gradually broadening above, the top gradually contracting to a rather broad anther-tube; anther-tube $1 \mathrm{~mm}$ long with a negligible curve and a straight orifice. Ovary covered with dense, stiff, short hairs; tapering at the top to a style $3 \mathrm{~mm}$ long and covered with short hairs. Ovules 2, 1 in each loculus, attached to the upper part of the axis. Fruit not seen.

Distribution: SW. Western Australia but otherwise unknown.

Specimens Examined: Western Australia: Drummond (MEL 1008033).

Knowledge of this species is confined to that obtainable from the Type specimen. Beard, W. Austral. Pl.: 56 (1965) refers to T. aphylla but his description must have been drawn from another species whose identity I have not been able to ascertain.

The affinities of $T$. aphylla are with $T$. paucifolia. Both have long filaments, attenuate anther-bases and broad anther-tubes, and both have short peduncles. However the long anther-body of $T$. aphylla and the larger dimensions of most parts serve to distinguish it from that species.

\section{Tetratheca paucifolia $J$. Thompson sp. nov.}

HoLoryPE: Cockleshell Gully, $\pm 115^{\circ} 6^{\prime}$ E. $30^{\circ} 9^{\prime}$ S, Western Australia, A.S. George 7822 , 9.1966 (NSW).

\section{ISOTYPE: PERTH.}

Fruticulus 10 ad plus quam $45 \mathrm{~cm}$ altus. Rami setis brevibus erectis et pilis minutis retrorsis vestiti. Folia alterna, usque ad $18 \mathrm{~mm}$ longa, anguste elliptica. Pedunculi 2-3 mm longi; receptaculo $1 \mathrm{~mm}$ diametro. Flores 4-meri vel 5-meri. Stamina filamentis c. $8 \mathrm{~mm}$ longis; tubis antherarum tenuibus, c. $1.25 \mathrm{~mm}$ longis. Ovarium pilis glanduliferis dense vestitum; ovulis 2 .

A sparsely-leaved or leafless many-stemmed shrub $10 \mathrm{~cm}$ to over $45 \mathrm{~cm}$ in height, much-branched near the base but more sparsely above, the stock branched and woody, perhaps rhizomatous. Stems terete, with scattered very short, stout, erect setae with an occasional glandular tip, and scattered areas of minute retrorse hairs or tubercles, the stems somewhat flexuose, $0.8-0.9 \mathrm{~mm}$ broad in the flowering region and ending in a point, the branching alternate and usually at rather an acute angle. Leaves alternate, very variable and tending to be clustered, to $18 \mathrm{~mm}$ in length but usually much shorter, in general narrowly elliptical, the margins loosely revolute with occasional short, stout, glandular hairs, the apex obtuse, blunt or with a glandular point, the upper surface covered with minute erect hairs, the lower pale and glabrous, the petiole distinct, often quite long and with an occasional glandular hair; on many branches the leaves reduced or deciduous. Flowers occurring among clusters of leaves or of leaf-bases, the bracts broad-linear, less than $1 \mathrm{~mm}$ in length and often hidden in the cluster. Peduncles $2-3 \mathrm{~mm}$ long, covered with dense, minute, white, stiff hairs and with numerous, broad-based, coloured, glandular hairs to $0.5 \mathrm{~mm}$ in length; twisted at the base, gradually broadening, darker and angled toward the top and widening only a little more at the extreme top to form a receptacle $1 \mathrm{~mm}$ in diameter. Calyx-segments 4 or 5 , persistent around the fruit, $2.5 \mathrm{~mm}$ long, elliptical, acute, dark-coloured, with sparse or numerous, broad-based, coloured, glandular hairs $0.5 \mathrm{~mm}$ long or even longer, with scattered, minute, stiff hairs between or on the glandular hairs, the inner surface with dense, fine, curled hairs especially on the margins and showing from the outside, the base of each segment attached at the top of the receptacle and not thickened. Petals 4 or 5, dark pink, obovate to cuneate, $8 \mathrm{~mm}$ long, and $5 \mathrm{~mm}$ wide with the greatest width near the top, deciduous. Stamens 8 or $10,4 \mathrm{~mm}$ long; filament c. $0.8 \mathrm{~mm}$ long and passing almost imperceptibly into the body of the anther; body of the anther with minute hairs or glabrous, $2 \mathrm{~mm}$ long with the lower $1 \mathrm{~mm}$ very slender, curved and resembling the filament, the broad part c. $1.25 \mathrm{~mm}$ long and tapering above to the anther-tube; anther-tube 
relatively broad and rather straight, c. $1.5 \mathrm{~mm}$ long with a narrow somewhat oblique orifice. Ovary covered with dense glandular hairs with broad stalks and with dense, short, erect hairs, the style $3 \mathrm{~mm}$ long, tapering to a slender tip and with some short hairs near the base. Ovules 2, 1 in each loculus, attached to the upper part of the axis. Fruit not seen in mature condition.

Distribution: On clay-loam or sand in scrub in SW. Western Australia. Map 3, see p. 159.

Specimens Examined: Western Australia: South Irwin and Darling Districts: Cockleshell Gully, George 7822, 9.1966 (PERTH, NSW); 8 miles [13 km] N. of Badgingarra, George 6727, 8.1965 (PERTH); \pm 8 miles [13 km] SW. of Beverley, Newbey 875, 8.1963 (PERTH). Without precise locality: Western Australia, Drummond 104, 1843 (NSW, a syntype of T. nuda var. spartea but not conspecific with the lectotype, see note under $T$. nuda).

$T$. paucifolia is in many aspects similar to $T$. aphylla but its more slender stems, smaller dimensions and longer, more dense, glandular hairs, and especially the smaller anthers with longer attenuate bases distinguish it from that species. No other Western Australian species has anthers so proportioned, though specimens of T. pilosa and allied species in Eastern Australia have some similarity.

6. Tetratheca harperi F. Muell., Fragm. 5: 49 (1865); F. Mueller, Syst. Census Austral. Pl. 1: 9 (1882); F. Mueller, Second Syst. Census 1: 15 (1889); Gardner, Enum. Pl. Austral. Occ.: 71 (1930); Blackall \& Grieve, Western Austral. Wildflowers 1: 259 (1954); Beard, W. Austral. Pl.: 56 (1965).

HoLOTYPE: Upon higher jasper ranges amongst the rocks, lat. $30^{\circ} 10^{\prime}$-long. $120^{\circ} 5^{\prime}$ [Western Australia], C. Harper (MEL 1007835), cited as 'In montibus jaspidosis inter rupes, $120^{\circ} 5^{\prime}, 30^{\circ} 10^{\prime}$, Australiae occidentalis interioris, Harper'.

A small leafless shrub 30 to perhaps $50 \mathrm{~cm}$ in height with rather stout stems, the stock not seen. Stems stout, glaucous, terete and vertically ridged when young but when mature densely covered with large tubercles bearing stout, usually straight, dark setae 1-2 mm long, the stems $1 \cdot 1-1 \cdot 3 \mathrm{~mm}$ broad in the flowering region, ending in a point, the branching alternate, often at an acute angle. Leaves alternate, c. $2 \mathrm{~mm}$ long, broadly obovate to lanceolate, the surface with some hairs but of glabrous aspect, the margins dentate with short setae on the teeth, the petiole conspicuous; soon deciduous, the mature branches leafless. Flowers occurring singly in the axils of leaf-bases, the bracts $0.5-1 \mathrm{~mm}$ long, ovate-concave, darkbrown, with some hairs and in clusters at the base of the peduncle. Peduncles c. $5 \mathrm{~mm}$ long, dark-coloured at least in the upper part, glabrous, widening and somewhat angled above and widening again at the extreme top to form a receptacle $1-1.5 \mathrm{~mm}$ in diameter. Calyx-segments 4 or 5 , deciduous, $2-2.5 \mathrm{~mm}$ long, ovate to elliptical, obtuse with a short point or acute, dark-coloured, glabrous except for a fringe of curled hairs inside the margin of the inner surface, the base of the segments attached inside the top of the receptacle and folded back over it with a thickened ridge along the lower back and a thicker area in the centre of it. Petals 4 or 5, dark pink with darker streaks towards the base of each, obovate but somewhat attenuate below, $10-12 \mathrm{~mm}$ long and c. $\frac{1}{2}$ as wide with the greatest width in the upper $\frac{1}{3}$, deciduous. Stamens $10,3.5 \mathrm{~mm}$ long; filament very short and stout; body of the anther $2.5 \mathrm{~mm}$ long, the base narrow and triangular in cross section and at an angle to the rest, the main part somewhat curved, tending to be covered with tubercles and with some stiff hairs, abruptly narrowed to a curved anther-tube; anther-tube $1.5 \mathrm{~mm}$ long, with a rather broad straight orifice. Ovary glabrous, on a distinct base and tapering at the apex to a rather stout style $2.5 \mathrm{~mm}$ long. Ovules 2, 1 in each loculus, attached to the upper part of the central axis. Fruit not seen.

Distribution: On stony ridges in inland SW. Western Australia. Map 3, see p. 159.

Specimens Examined: Western Australia: Coolgardie District: $30^{\circ} 10^{\prime} \mathrm{S} 120^{\circ} 5^{\prime} \mathrm{E}$, high jasper ranges. Harper (MEL 1007835); Mt Jackson, N. of Southern Cross, Tonkinson 9. 1967 (PERTH). 
This species has some affinity with $T$. halmaturina, although it differs markedly in general aspect. The dense covering of erect tubercle-based setae distinguishes it from all other species.

7. Tetratheca halmaturina $J . M$. Black in Trans. Proc. Roy. Soc. South Australia 48: 257 (1924); J. M. Black, Fl. South Australia 2: 347 (1924) and [ed. 2] 2: 503 (1948).

TYPE: A single sheet from Black's herbarium, AD97406418, consists of more than one fragmented specimen together with dissections and sketches. It bears two labels, "Cape Cassini, Kangaroo Island, $\boldsymbol{H}$. H. D. Griffith, 21.10.1908" and "Between Vivonne Bay and Rocky R, Kangaroo Island, $\boldsymbol{J}$. $\boldsymbol{B}$. Cleland, 11.10.1924". Black cited only Kangaroo Island, with no collector or date, with his original description but the Cleland collection was made after his paper was read and cannot be considered type material.

Synonymy: Tetratheca ericifolia var. aphylla Tate in Trans. Proc. Roy. Soc. South Australia 12: 62 (1889) non F. Muell., Pl. Indig. Colony Victoria 1: 183 (1860-1862). HolotyPE: Karatta, Kangaroo Island [South Australia], O. Tepper 13, 11.xi.1886 (MEL 1007834). Tepper cited this specimen in a list published in Trans. Proc. Roy. Soc. South Australia 10: 290 (1888). His specimens were later submitted for Tate's examination. Tate may have intended to base this variety on T. aphylla F. Muell. but he has not done this in accordance with Art. 32 of the International Code of Botanical Nomenclature (1972).

A compact, almost leafless shrub c. $20 \mathrm{~cm}$ in height with rigid stems, usually branching above and close to a branched stock, the branches first spreading then erect. Stems stout, terete or with longitudinal ridges, covered with small tubercles and scattered large ones, the larger occasionally bearing brown setae to $1 \mathrm{~mm}$ in length or red glandular-tipped hairs, the stems $1.1-1.8 \mathrm{~mm}$ broad in the flowering region and usually ending in a blunt point, the branching alternate and at an acute angle. Leaves alternate except on juvenile parts where they are occasionally irregularly whorled, seen only at the base of the stems and then only in a few specimens, 4-6 mm long, obovate to rhomboid, the upper surface with very short stiff hairs, the lower paler and glabrous, the margins flat or recurved, sparsely and coarsely dentate, the apex with a blunt incurved point, the petiole short but distinct; on most plants all the leaves reduced to narrowly deltoid green scales usually with the top withering and leaving the short broad base of the petiole. Flowers occurring singly or 2 together in the axils of scale leaves on upper branches, with the bracts minute to $1 \mathrm{~mm}$ long, brown, linear to lanceolate, usually acuminate and with fine hairs on the upper surface. Peduncles 5-8 mm long, glabrous, broadening and somewhat angled in the upper part and expanding gradually or abruptly into a receptacle usually $1.5 \mathrm{~mm}$ in diameter, the top of the receptacle incurved but hidden by the base of the calyx-segments. Calyx-segments 5, deciduous but sometimes tardily so, usually dark-coloured and shining, $2 \cdot 5-3 \mathrm{~mm}$ long, obtuse to acuminate, the visible part of each ovate to broadly ovate with a bulging thickened area right across the dorsal surface above the rim of the receptacle, the actual base of the segment attached well inside the rim of the receptacle, glabrous on the outer surface with some shining spots, the inner surface with some fine hairs near the margin. Petals usually 5, dark pink, rarely white, usually broad-linguiform, 9-13 $\mathrm{mm}$ long and less than $\frac{1}{2}$ as wide with the greatest width in the upper $\frac{1}{4}$, deciduous. Stamens usually $10,3.2-3.5 \mathrm{~mm}$ long; filament usually less than $0.25 \mathrm{~mm}$ long; body of the anther $2.25-2.5 \mathrm{~mm}$ long, glabrous or with minute protuberances, the lower $0.5 \mathrm{~mm}$ somewhat flattened and gently curved, contracting at the apex to a curved anthertube; the anther-tube $0.75-1.5 \mathrm{~mm}$ long, somewhat variable and tapering to a variable but rather narrow orifice with a curved lip. Ovary glabrous or with scattered glandular-tipped very broadly based hairs especially on the conspicuous broad base, occasionally also with some minute straight hairs; turgid, tapering at the apex into a rather stout style $2-2.5 \mathrm{~mm}$ long and glabrous or more frequently with minute hairs on the base. Ovules 2, 1 in each loculus, attached to a broad or projecting part of the axis. Fruit $6-8 \mathrm{~mm}$ long and $2 \cdot 5-3 \mathrm{~mm}$ wide, narrowly obovate, usually shortly beaked, the seeds scarcely leaving a scar on the axis. Seeds $3.5-4 \mathrm{~mm}$ long, cylindrical, tapering at the base, slightly curved, flattened or concave on the axial 
side with a scar near the base and the apex flat; brown, with very fine spreading hairs, the appendage cream, the upper part white, irregularly coiled beyond the seed in c. 2 coils, with short fine hairs.

Distribution: In scrub, Kangaroo Island, South Australia. Map 10, see p. 205.

Specimens Examined (Selection Only): South Australia: Kangaroo Island: Stokes Bay-Middle R, Rogers NSW 125106, 9.1908 (NSW); Middle R, Ashby 230, 10.1905 (NSW); Snug Cove, Rogers NSW 125111, 9.1908 (NSW); by main Kingscote-Cape Borda road, $12 \mathrm{~km}$ E. of Cape Borda, Schodde 537, 12.1957 (AD, CANB); 4 miles [6 km] E. of Cape Borda, Phillips 8. 1964 (CBG 023815, NSW); c. 3 km W. of Ravine de Casaors, Flinders Chase, Wace 8.1965 (AD); Parndana, c. $45 \mathrm{~km}$ WSW. of Kingscote, Jackson 256, 7.1963 (AD); Playford Highway, 2 miles [3 km] E. of Western Highway, Phillips 9.1965 (CBG 025220, AD); just E. of West End Highway, c. $15 \mathrm{~km}$ NW. of "Rocky R" homestead, Eichler 1.1966 (AD); Upper Breakneck R at crossing with Shackle road, c. $21 \mathrm{~km} \mathrm{~S}$. of Cape Borda road, Eichler 15140, 11.1958 (AD); Sandy Creek, Rogers NSW 125108 (NSW); Flinders Chase near Rocky R, Wigan 10.1952 (MEL); about $5 \mathrm{~km} \mathrm{~N}$. of Mt Taylor, c. $10 \mathrm{~km} \mathrm{NW}$. of Vivonne Bay, Jackson 556, 10.1967 (AD); "Karatta" Station, Tepper 11.1886 (MEL 1007834); Kelly Hill, c. $12 \mathrm{~km}$ ENE. of Cape de Couedic, Wilson 727, 11.1958 (AD); track from mouth of Harriet $\mathbf{R}$ to Harriet Bridge, Vivonne Bay, Jackson 478, 9.1966 (AD); Kangaroo Island, Staer NSW 125110, 3.1911 (NSW).

The affinities of this species do not appear to lie with other Eastern Australian species but with the leafless Western ones especially $T$. harperi which has similarities in many of its characters such as the dimensions of the receptacle and the anthers.

8. Tetratheca nuda Lindl. in Edwards' Bot. Reg. App. Swan River: 38 (1840); Walpers, Repert. Bot. Syst. 1: 249 (1842); Steetz in Lehmann, Pl. Preiss. 1: 213 (1845); Walpers, Repert. Bot. Syst. 5: 68 (1845); Steetz, Familie Tremandreen: 10 (1853); Schuchardt, Syn. Tremandr.: 19 (1853); Bentham, Fl. Austral. 1: 133 (1863); F. Mueller, Fragm. 12: 5 (1882); F. Mueller, Syst. Census Austral. Pl. 1: 9 (1882); F. Mueller, Second Syst. Census 1: 15 (1889); Diels \& Pritzel in Bot. Jahrb. Syst. 35: 330 (1904); Gardner, Enum. Pl. Austral. Occ.: 71 (1930); Blackall \& Grieve, Western Austral. Wildflowers 1: 260 (1954); Beard, W. Austral. P1.: 56 (1965).

SynTYPeS: Mountains, Swan River [Western Australia], Mangles; Swan River, Toward 56; Swan River, Drummond 1839. I have seen only photographs of these specimens which are in the Cambridge University Herbarium.

A small leafless shrub 15 to $40 \mathrm{~cm}$ in height with numerous slenders tems arising from a stout, woody, apparently rhizomatous stock, the stems often branching in the lower part but not immediately above the stock. Stems slender, terete or somewhat longitudinally ridged, glabrous or with scattered stout white setae or with scattered glandular-tipped hairs, occasionally with areas of minute hairs, the stems $0.5-0.8 \mathrm{~mm}$ broad in the flowering region, usually ending in a point, the branching alternate and usually at an acute angle. Leaves alternate, up to $5 \mathrm{~mm}$ long, elliptical, the tip usually with a stiff point, the margins flat or revolute with scattered glandular hairs, the blade tapering to a long petiole; on mature branches the leaves reduced to triangular scales. Flowers occurring singly in the axils of upper scale-leaves with bracts $0 \cdot 5-1 \mathrm{~mm}$ long, linear-lanceolate, brown and with hairs on the upper surface. Peduncles c. $7 \mathrm{~mm}$ long, dark-coloured, glabrous or with broad-based, slender-necked, dark-tipped, spreading or even retrorse glandular setae, often $0.5 \mathrm{~mm}$ or more in length; much expanded at the top to form a receptacle $1-1.5 \mathrm{~mm}$ in diameter. Calyx-segments 5 , deciduous, dark-coloured, usually $2.5 \mathrm{~mm}$ long, glabrous, or rarely with occasional glandular setae except on the inner surface which has fine hairs especially near the margin; ovate, acute or more frequently acuminate, the base of each segment attached inside the top of the receptacle and folded back over it with a conspicuous thickened area in the centre of the lower back. Petals 5, dark pink, occasionally white, usually broadly linguiform and often conspicuously narrowed at the base, less frequently obovate or broadly cuneate, $6-8 \mathrm{~mm}$ long and usually more than $\frac{1}{2}$ as wide, though sometimes less, with the greatest width close to the top, deciduous. Stamens usually 8-10, 2.5-3 mm long; filament very short, less than $0.25 \mathrm{~mm}$ long; body of the anther somewhat flattened at the base then often strongly curved or angled, $2 \mathrm{~mm}$ long, dark purple, smooth and shining but usually with 
minute hairs, tapering into the anther-tube; anther-tube only $0.5 \mathrm{~mm}$ long, sometimes tipped with yellow. Ovary pubescent with glandular hairs; more or less expanded at the base to form a short thick stalk to the young fruit, the style slender, $2 \mathrm{~mm}$ long. Ovules 2, 1 in each loculus, attached by a rather long placenta to the upper part of the central axis. Fruit cuneate, somewhat 2-lobed at the top, $8 \mathrm{~mm}$ long and $4 \mathrm{~mm}$ wide near the top, the surface covered with minute hairs and broad-based glandular-tipped hairs. Seeds not seen.

Distribution: In sandy heath and sclerophyll forest in SW. Western Australia. Map 3, see p. 159.

Specimens Examined (Selection Only): Western Australia: Darling District: Smiths Mill, Darling Range, Morrison 11.1899 (BRI, MEL); Red Hill, Aplin 321, 11.1958 (PERTH); c. 26 mile [42 km] peg on Perth to Toodyay road, Parratt 1583, 11.1965 (AD); Upper Swan R, Sewell 1882 (MEL 1008237 in part); Wooroloo, Koch 1521, 10.1907 (AD); Wooroloo, Darling Range, Koch 1521, 9.1906 (MEL, NSW); Midland Junction, Fitzgerald NSW 125104, 9.1900 (NSW); Swan View, Helms NSW 125098, 10.1899 (NSW); Greenmount, Darling Range, Hamilton NSW 125101, 1902 (NSW); hills between Darlington and Bellevue, White 5232, 11.1927 (BRI); Helena Vale, Lambert 9.1900 (PERTH); Gooseberry Hill, Darling Range, Wakefield 10.1917 (PERTH); Perth, Maiden NSW 125100, 10.1909 (NSW); Perth, Sheath NSW 125102, 12.1910 (NSW); Swan R, Mylne (MEL); Darling Range, district Swan, Pritzel 720, 9.1901 (AD, NSW, PERTH); Darling Range, Oldfield (MEL); Welshpool to Kalamunda, Maiden NSW 125096, 9.1909 (NSW); Beenup, Canning R, Morrison 14111, 11.1904 (AD, BRI, PERTH). Without precise locality: W.A., Drummond 106, 1843 (MEL, NSW); in Nova Hollandia occidentali, Preiss 1332 in part (MEL 1007885, 1007886).

The affinities of this species are obscure. Its stamens differ from those of all the other species and serve to distinguish it from the superficially similar T. virgata.

Tetratheca nuda var. spartea Planch. ex Benth., Fl. Austral. 1: 133 (1863) is based on two specimens: Drummond Coll. 1843, n. 101 and 104 [Herb. Hook.]. Lectotype (here chosen): Swan R [Western Australia], Drummond 101 herb. Hook., $1843(\mathrm{~K})$. I have seen a photograph of this specimen and MEL 1008122 is apparently a duplicate. I have selected this specimen as lectotype because it is very similar to and obviously related to $T$. nuda. However its difference, the long anther-tube and the dark patch at the base of each petal, must be regarded as significant. This collection may represent a closely related species but it is also possible that it represents a hybrid between $T$. nuda and another species, perhaps $T$. hirsuta. The other collection, Drummond 104 herb. Hook., 1843 (K, dupl. NSW 125190) is included in T. paucifolia. F. Mueller, Fragm. 12: 5 (1882), includes this variety in T. virgata.

9. Tetratheca pilifera Lindl. in Edwards' Bot. Reg. App. Swan River: 38 (1840); Walpers, Repert. Bot. Syst. 1: 249 (1842); Lehmann, Pl. Preiss. 2: 233 (1848); Steetz, Familie Tremandreen: 11 (1853); Schuchardt, Syn. Tremandr.: 42 (1853); Bentham, Fl. Austral. 1: 135 (1863); F. Mueller, Fragm. 12: 8 (1882); F. Mueller, Syst. Census Austral. P1. 1: 9 (1882); F. Mueller, Second Syst. Census 1: 15 (1889); Gardner, Enum. Pl. Austral. Occ.: 71 (1930); Blackall \& Grieve, Western Austral. Wildflowers 1: 260 (1954); Beard, W. Austral. P1.: 56 (1965).

HoLotype: Swan River [Western Australia], Drummond 1839. I have seen only a photograph of this specimen which is in the Cambridge University Herbarium.

SynONYMy: Tetratheca preissiana Steetz in Lehmann, PI. Preiss. 1: 219 (1845); Walpers, Repert. Bot. Syst. 5: 69 (1845). HolOTYPE: In saxosis montis prope Cataractam ad caput (sic!) fluminis 'Swan river' in Nova Hollandia occidentali, Preiss 1323, 25.vii.1839 (MEL 1007889). The specimens 1323 (MEL 1008405) and Preiss 1323 (MEL 1007893 in part) are probably Isotypes.

Tetratheca preissiana var. integrifolia Steetz in Lehmann, PI. Preiss. 1: 220 (1845); Walpers, Repert. Bot. Syst. 5: 70 (1845). HolotyPE: In limoso-calculosis districtus "York" in Nova Hollandia occidentali, Preiss 1324, 12.ix.1839 (MEL 1007895). The specimen Preiss 1324, 12.ix.1839 (MEL 1007893) is probably an Isotype.

Tetratheca micrantha Schuchardt, Syn. Tremandr.: 43 (1853). HolotyPE: As for $T$. preissiana var. integrifolia. 
A small shrub $15-20 \mathrm{~cm}$ in height with many stems arising from a stout woody stock and branching frequently for most of their length. Stems slender, terete, somewhat thicker below the nodes, glabrous or more often with fine spreading or curved white hairs which are often retrorse for the most part but antrorse under the nodes, and often with at least a few, occasionally with many, long brown setae to $3 \mathrm{~mm}$ in length, often with swollen bases, especially just below the nodes; the stems $0.3-0.7 \mathrm{~mm}$ broad in the flowering region and often but not always with several branches arising at one point, usually at an acute angle. Leaves in whorls of 3 or occasionally a few opposite towards the base of some branches, ovate to triangular, to $15 \mathrm{~mm}$ in length but usually less than $10 \mathrm{~mm}$, the apex often with a point, the margins with points or long setae on the teeth, recurved or revolute between the teeth, the upper surface glabrous or covered with erect hairs, the lower very pale, glabrous or with hairs especially on the midrib, the petioles short but bearing spinelike setae. Flowers occurring singly or several together in upper leaf-axils, the bracts c. $0.5 \mathrm{~mm}$ long, dark brown, linear-lanceolate and with hairs on the upper surface. Peduncles pale or very dark-coloured, lengthening as the flower matures, usually 10-17 $\mathrm{mm}$ long in the mature flower, thickened and rather strongly curved at the top and at the extreme top abruptly thickened into a receptacle, the receptacle c. $1 \mathrm{~mm}$ in diameter, glabrous or with rather sparse, fine, spreading, straight hairs to $0.5 \mathrm{~mm}$ in length. Calyx-segments 4 or 5 , deciduous, very dark-coloured, $2.5-3 \mathrm{~mm}$ long, ovate to elliptical, obtuse to acuminate, glabrous except for fine hairs near the inner margin, each segment attached well inside the top of the receptacle with a ridge across the lower part and a large thickening in the centre of the lower back. Petals 4 or 5 , purple, dark at the base, broadly ovate to broadly linguiform, 6-8 $\mathrm{mm}$ long and $\frac{1}{2}$ or more than $\frac{1}{2}$ as wide with the greatest width in the upper $\frac{1}{3}$, deciduous. Stamens usually 8 or $10,2 \cdot 5-3 \mathrm{~mm}$ long; filament very slender, c. $1 \mathrm{~mm}$ long; body of the anther $2-2.5 \mathrm{~mm}$ long, expanding rather abruptly above the filament, yellow or purple-tinged, smooth, scarcely contracting to the anther-tube; anther-tube broad, $0.5 \mathrm{~mm}$ or less in length with a wide straight orifice (fig. 4). Ovary densely pubescent, on a short thick base, the rather short and slender style $2 \mathrm{~mm}$ long. Ovules 2,1 in each loculus, each suspended from a swollen and often reddish placenta at the top of the central axis. Fruit globular-compressed, $4 \mathrm{~mm}$ long and $5 \mathrm{~mm}$ wide, somewhat 2-lobed at apex and base, contracted at the centre, turgid each side of the axis at the top, flattened at the base, the axis thickened at the placenta. Seeds very turgid, obovoid but flatter on the adaxial side, c. $3 \mathrm{~mm}$ long, red-brown, shining and with a few fine spreading hairs, with a scar near the base of the adaxial surface, the appendage coiled towards the axis, with sparse fine spreading hairs.

DistrIbUtion: In gravelly soil in SW. Western Australia, Map 4, see p. 167.

Specimens Examined (Selection Only): Western Australia: Northern Darling District: Old Victoria Plains road, N. of Toodyay, Willis 9.1963 (MEL, NSW); in saxosis montis prope Cataractum ad caput (sic!) fluminis Swan river, Preiss 1323, 7.1839 (MEL 1007889, 1007893 in part); in arenosis montis prope Cataractum versus caput fuvii Swan R, Preiss 1323 (the number 1319 is given in error on the label) (MEL 1008405); Upper Swan R, Sewell 1882 (MEL); Upper Swan R, Sewell 1885 (MEL); O'Brien Road, Darling Range, Saffrey 68, 8.1963 (PERTH); Woorooloo, Koch 1411 (BRI); Woorooloo, Koch 1411, 8.1906 (MEL, NSW, PERTH); Woorooloo, Koch 1411, 9.1907 (AD, NSW); in limoso-calculosis districtus York, Preiss 1324, 9.1839 (MEL 1007893 in part, 1007895); National Park, Swan View, Stobie 8.1930 (PERTH). Without precise locality: Western Australia, Drummond, 1st Coll. 103, 1843 (MEL, NSW).

Schuchardt, Syn. Tremandr.: 43 (1853) incorrectly attributes the varietal combination T. pilifera var. integrifolia to Steetz, Pl. Preiss. 2: 234 (1848).

T. pilifera is the only purple-flowered Tetratheca and the only species of the genus to have the slender filament and broad anther-orifice of stamens of Tremandra. Dried specimens are extremely similar in aspect to Tetratheca similis but can be distinguished immediately by their stamens. 


\section{MAP 4}
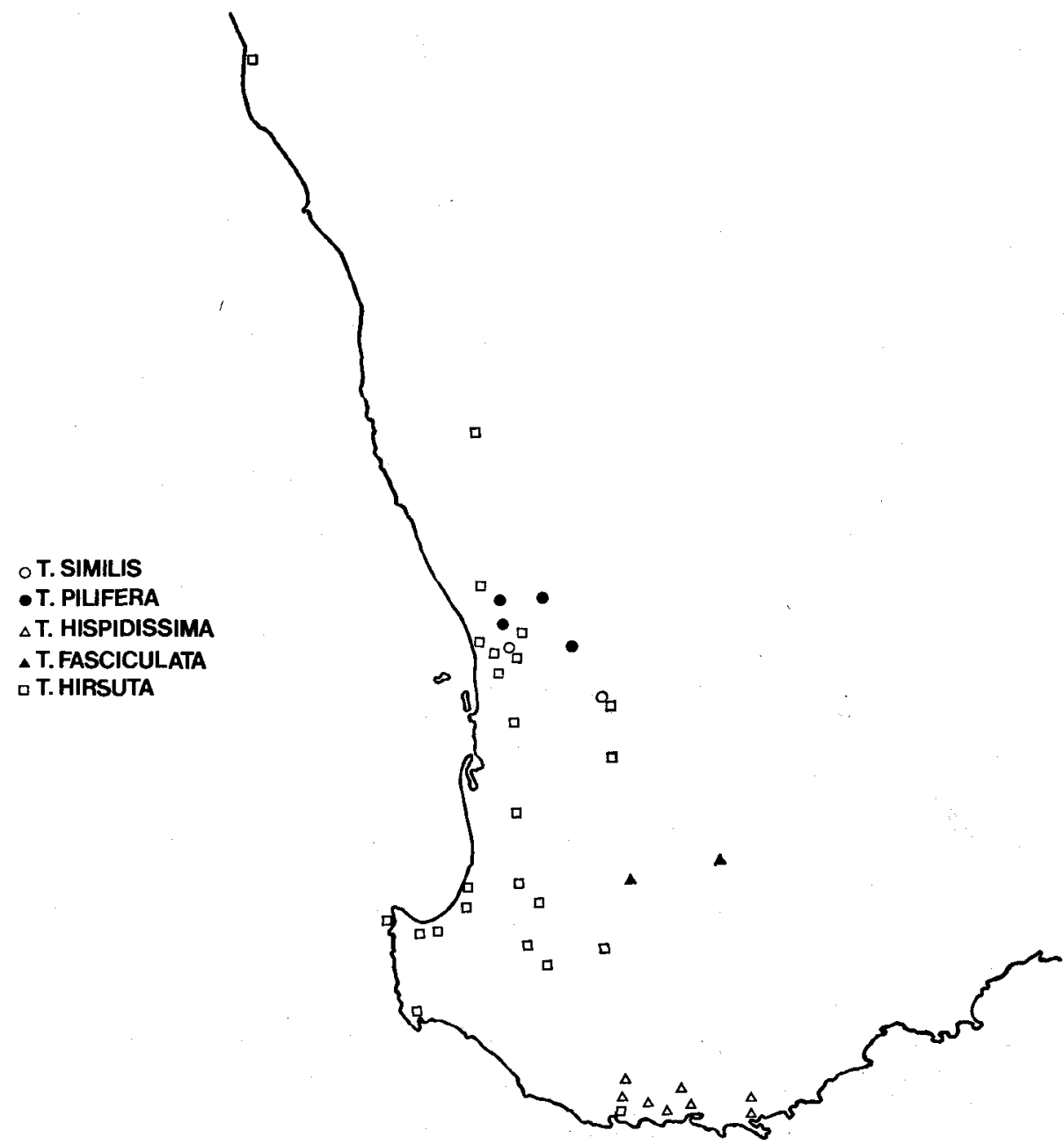

10. Tetratheca hirsuta Lindl. in Edwards' Bot. Reg. App. Swan River : 38 (1840); Walpers, Repert. Bot. Syst. 1: 249 (1842); Lindley in Bot. Reg., n.s. 7: 67 (1844); Paxton in Mag. Bot. 13: t. 53 (1846); Payer in Ann. Sc. Nat. Bot., [Ser. 3] 15: 351 (1851); Bentham, Fl. Austral. 1: 134 (1863); F. Mueller, Fragm. 12: 7 (1882); including T. hispidissima; F. Mueller, Syst. Census Austral. Pl. 1: 9 (1882); F. Mueller, Second Syst. Census 1: 15 (1889); Diels \& Pritzel in Bot Jahrb. Syst. 35: 330 (1904); Gardner, Enum. Pl. Austral. Occ.: 71 (1930); Beard, W. Austral. P1.: 56 (1965).

HoLOTYPE: Swan River [Western Australia], Toward 51. I have seen only a photograph of this specimen which is in the Cambridge University Herbarium.

SYNONYMY: Tetratheca viminea Lindl. in Edwards' Bot. Reg. App. Swan River: 38 (1840); Walpers, Repert. Bot. Syst. 1: 249 (1842); Steetz in Lehmann, Pl. Preiss. 1: 216 (1845); Walpers Repert. Bot. Syst. 5: 69 (1845); Steetz, Familie Tremandreen: 11 (1853); Schuchardt, Syn. Tremandr.: 34 (1853); Bentham, Fl. Austral. 1: 134 (1863); Diels \& Pritzel in Bot. Jahrb. Syst. 35: 330 (1904); Gardner, Enum. Pl. Austral. Occ.: 71 (1930) including T. pubescens Turcz.; Blackall \& Grieve, Western Austral. Wildflowers 1: 260 (1954); Beard, W. Austral. PI.: 56 (1965). HolotyPE: Swan River [Western Australia], Mangles. I have seen only a photograph of this specimen which is in the Cambridge University Herbarium. 
Tetratheca rubriseta Lindl. in Edwards' Bot. Reg. App. Swan River: 38 (1840); Walpers, Repert. Bot. Syst. 1: 249 (1842); Steetz in Lehmann, Pl. Preiss. 2: 234 (1848); Walpers, Ann. Bot. Syst. 2: 87 (1851); Steetz, Familie Tremandreen: 11 (1853); Schuchardt, Syn. Tremandr.: 40 (1853). Syntypes: Swan River [Western Australia], Mangles; Swan River [Western Australia], Drummond. I have seen only photographs of these specimens which are in the Cambridge University Herbarium.

Tremandra hugelii Hort. ex Lindl. in Bot. Reg., n.s. 7: 67 (1844) nomen nudum, in synon.

Tetratheca viminea var. microphylla Steetz in Lehmann, P1. Preiss, 1: 216 (1845); Walpers, Repert. Bot. Syst. 5: 69 (1845); Schuchardt, Syn. Tremandr.: 36 (1853). HolotyPE: In arenosis sylvae prope urbiculam "Albany" (Plantagenet) in Nova Hollandia occidentalis, Preiss $1318,11.1840$ (MEL 1008085).

Tetratheca viminea var. setosa Steetz in Lehmann, P1. Preiss. 1: 217 (1845); Walpers, Repert. Bot. Syst. 5: 69 (1845); Schuchardt, Syn. Tremandr.: 36 (1853); Diels \& Pritzel in Bot. Jahrb. Syst. 35: 330 (1904). HolotyPE: In subarenosis sylvae ad fluvium "Vasse River" (Lussen) in Nova Hollandia occidentalis, Preiss 1317, 24.xii.1839 (MEL 1008086).

Tetratheca epilobioides Steetz in Lehmann, Pl. Preiss. 1: 218 (1845); Walpers, Repert. Bot. Syst. 5: 69 (1845); Walpers, Ann. Bot. Syst. 2: 87 (1851); Steetz, Familie Tremandreen: 11 (1853); Schuchardt, Syn. Tremandr.: 36 (1853). HoLoTyPE: In limoso-calculosis sylvae inter "Mahogany creek" et "Halfwayhouse" (Darlings Range) in Nova Hollandia occidentali, Preiss 1325, 13.ix.1839 (MEL 1007845). The specimens Preiss 1325 (MEL 1007846 and MEL 1007847) are probably Isotypes.

Tetratheca aculeata Steetz in Lehmann, Pl. Preiss. 1: 218 (1845); Walpers, Repert. Bot. Syst. 5: 69 (1845). HolotyPE: In Nova Hollandia occidentalis, Preiss 1319 (MEL 1007848).

Tetratheca gracilis Steetz in Lehmann, P1. Preiss. 1: 215 (1845); Walpers, Repert. Bot. Syst. 5: 69 (1845); Schuchardt, Syn. Tremandr.: 22 (1853). HolotYPE: In subarenosis sylvae ad fluvium "Serpentine River"' (Murray) in Nova Hollandia occidentali, Preiss 1335, 5.xii.1839 (MEL 1008091). IsOTYPE: Preiss 1335 (MEL 1009092).

Tetratheca epilobioides var. hirsuta (Lindl.) Steetz in Lehmann, Pl. Preiss. 2: 233 (1848); Walpers, Ann. Bot. Syst. 2: 87 (1851); Schuchardt, Syn. Tremandr.: 37 (1853). HolotyPE: As for T. hirsuta.

Tremandra floribunda Hort. ex Steetz, in Lehmann, Pl. Preiss. 2: 233 (1848) nomen nudum, in synon.

Tetratheca mollis Pritzel ex Diels et Pritzel in Bot. Jahrb. Syst. 35: 330 (1904) nomen nudum, in synon.

An erect or weak shrub to $90 \mathrm{~cm}$ in height with a number of stems arising from a woody, perhaps rhizomatous, stock, the stems sparsely branched, sometimes near the stock, sometimes in the upper part. Stems terete, usually covered with tubercles and at least in the upper part with dense, fine, white, curled hairs and a few to numerous, reddish-brown, tubercle-based setae to $2 \mathrm{~mm}$ in length, and occasionally with some glandular-tipped hairs interspersed, rarely almost glabrous but with a few setae below the nodes, while in a few specimens the hairs between the setae are short, dense, white and almost straight; the stems $0 \cdot 3-2 \cdot 3 \mathrm{~mm}$ broad in the flowering region, the branching usually but not always alternate and usually at an acute angle. Leaves alternate, opposite or in whorls of 3 or more, broadly to narrowly elliptical, occasionally wider at the top, more frequently broader near the base so as to be somewhat ovate, very variable in length even on one branch, usually 5-20 mm but often longer or shorter, the tip incurved, of ten with a minute point, the margins flat, recurved or revolute, often with hairs, occasionally glandular, rarely with such stout hairs as to appear dentate, the upper surface pubescent, of ten with stiff hairs, or glabrous, the lower usually with a dense silky pubescence but occasionally the pubescence sparse or even absent and then the lower surface is seen to be paler than the upper, the petiole short but distinct. Flowers occurring singly in the axils of upper leaves, with bracts c. $1 \mathrm{~mm}$ long, light to dark brown, linear-lanceolate and hairy at least on the upper surface. Peduncles 7-32 mm long, pale or dark-coloured, glabrous or with long, coloured, broad-based, glandular-tipped spreading hairs, to $0.5 \mathrm{~mm}$ or more in length, occasionally also with spreading, short, fine, white hairs, broadening and angled at the top to form a receptacle variously but rarely more than moderately expanded at the top, with the top angled in under the calyx-lobes. Calyx-segments 5, deciduous, dark-coloured to pale and somewhat scarious, $3-4 \mathrm{~mm}$ 
long, elliptical to narrowly ovate, obtuse to long-acuminate, glabrous or with few or numerous glandular hairs, especially on the margin, or a few fine white hairs, the inner surface with a fringe of fine, curled hairs inside the margin and straight hairs on the central ridge, the base of each segment attached well inside the top of the receptacle and folded back over it with a very thick turgid ridge on the lower back above the edge of the receptacle. Petals 5, dark pink with a darker patch at the base or, not infrequently, white with a dark patch, ovate to broadly linguiform, often. somewhat diamond-shaped, the edges strongly folded in the bud and with an undulate margin, $7-15 \mathrm{~mm}$ long and c. $\frac{1}{2}$ as wide with the greatest width usually near the centre, deciduous. Stamens 10 , c. $5 \mathrm{~mm}$ long; filament c. $1 \mathrm{~mm}$ long, almost terete and often joined with the other filament in front of the same petal, sometimes only at the base, often for most of its length; body of the anther expanding abruptly above the filament and often extending behind it, $2 \mathrm{~mm}$ long and covered with minute tubercles, at the apex narrowing into a tapering tuberculate anther-tube; anther-tube $2.5 \mathrm{~mm}$ long and with a narrow orifice (fig. 4). Ovary glabrous except: for a cluster of silky hairs at the apex and on the sides, or hairy all over and with or without scattered glandular hairs with flat stalks, the latter are usually present when the peduncles have glandular hairs, the ovary on a short broad base with a straight or somewhat kinked style $3 \mathrm{~mm}$ or more in length. Ovules 2,1 in each loculus, suspended from the top angle of the central axis, the axis thickened but the placenta not swollen (fig. 5). Fruit obcordate or broadly cuneate-oblong, turgid, 5-8 mm long and almost as broad, with no thickening on the axis. Seeds $3.5 \mathrm{~mm}$ long, very turgid, obovoid but flattened on the adaxial side, shining, red-brown, with sparse fine spreading hairs, the adaxial side with a long scar, the appendage coiled towards the axis, with short spreading hairs. p. 167.

Distribution: In heath and forest on light soils in SW. Western Australia. Map 4, see

Specimens Examined (Selection Only): Western Australia: Irwin District: Geraldton, Stoward 9.1917 (PERTH). Darling District: Julimar State Forest, 50 miles [81 km] N. of Perth, C.L.W. 8.1957 (PERTH); 4.5 miles [7 km] from Gingin towards Bindoon, Canning 9.1968 (CBG 028710); on Toodyay Road, $1 \frac{1}{2}$ W. of Bunning Road, Darling Range, Vasek 681006-50, 10.1968 (CANB); Wanneroo, Fitzgerald NSW 119566, 11.1901 (NSW); near Wundowie, Salasoo 491, 11.1949 (NSW); Woorooloo, Koch 1410a, 9.1908 (AD, NSW); Upper Swan R past Guildford, Morris 9.1947 (MEL); Sawyer Valley, Mundaring, Willis 9.1947 (MEL); in limoso-calculosis sylvae inter "Mahogany Creek" et "Halfwayhouse", Preiss 1325, 9.1839 (MEL $1007845,1007846,1007847$ ); hills between Darlington and Bellevue, White 11.1927 (BRI); Bayswater, Morrison 10.1901 (PERTH); Leederville, Helms 11.1899 (BRI); District Swan, in silvis subumbrosis montium Darling Range, Pritzel 506, 8.1901 (NSW, PERTH); District Swan, in silvis apertis arenosis Eucalypti marginatae, Pritzel 4, 11.1900 (AD, NSW); in silvis apertis arenosis Eucalypti marginatae, Pritzel 786, 10.1901 (AD, NSW, PERTH); Darling scarp below Kalamunda, Souster 542, 10.1946 (NSW); Welshpool to Kalamunda, Maiden NSW 119548, $119549,9.1909$ (NSW); Brookton-Kelmscott road along track to Warrawoona, Aplin 197, 9.1958 (PERTH); in subarenosis sylvae ad fluvium "Serpentine River", Preiss 1335 (MEL 1008091, 1008092); near 37 mile [60 km] peg, Perth-Albany road, Burbidge 2249, 9.1947 (CANB, BRI); 59.2 miles [95 km] from Perth towards Williams, Canning 9.1968 (CBG 029372); North Bannister, Mahon, Rogers \& Common 0369, 9.1951 (CANB); Dwellingup, Gardner 6483, 9.1942 (PERTH); near Yarloop, Went 231, 9.1962 (PERTH); Samsons Brook, Berthoud 10.1902 (PERTH); Collie R, district Wellington, Pritzel 803, 10.1901 (PERTH). Warren District: Geographe Bay, Bunbury 1874 (MEL 1008095, 1008196); Queenwood, Preston district, Koch 2039, 10.1910 (BRI, NSW); Busselton-Bunbury road area, Webb 2939, 8.1958 (BRI); Busselton, Stoward 39, 11.1911 (NSW); in subarenosis sylvae ad fluvium "Vasse River", Preiss 1317, 12.1839 (MEL 1008086); Yallingup, Gardner 5565, 9.1940 (PERTH); 8 miles [13 km] N. of Bridgetown, Belcher 191, 9.1967 (AD, CANB, MEL); 26 miles [42 km] SW. of Kojonup, Burbidge 2541, 9.1947 (CANB); Lower Blackwood R, Pulleine NSW 119593, 12.1917 (NSW); 8-10 miles [13-16 km] from Nornalup, Pulleine NSW 11955, 12.1917 (NSW); in arenosis sylvae prope urbiculam "Albany", Preiss 1318, 11.1840 (MEL 1008085). Without precise locality: Western Australia, Drummond 108, 1843 (MEL, NSW); in Nova Hollandia occidentalis, Preiss 1319. (MEL 1007848).

A specimen labelled Mt Drummer, Vic., Hunter 11.1937 (NSW 119554, ex Nat. Herb. Melbourne) belongs to this species but I am assuming that there has. been some confusion and it was not collected in Victoria.

Diels \& Pritzel in Bot. Jahrb. Syst. 35: 330 (1904) refer to T. hirsuta Lindl. var. epilobioides Steetz but Steetz used T. epilobioides var. hirsuta.

G 13570-39 
This species is extremely variable and seems to parallel the Eastern Australian $T$. thymifolia in that its variability may be divisible into meaningful forms with further study. $T$. hispidissima is very closely related to $T$. hirsuta but does merit recognition as a separate species. Both these species differ from all others in bearing extremely long tapering tuberculate anther-tubes which resemble those of Platytheca spp.

11. Tetratheca hispidissima Steetz in Lehmann, Pl. Preiss. $1: 217$ (1845); Walpers, Repert. Bot. Syst. 5: 69 (1845); Steetz, Familie Tremandreen: 11 (1853); Schuchardt, Syn. Tremandr.: 41 (1853); Bentham, Fl. Austral. 1: 134 (1863); Gardner, Enum. Pl. Austral. Occ.: 71 (1930); Beard, W. Austral. Pl.: 56 (1965).

Holotype: In arenosis sylvae ad sinum regis Georgii III in Nova Hollandia occidentali, Preiss 1316, 10.1840 (MEL 1007872).

A shrub to $60 \mathrm{~cm}$ in height with stems arising from a stock which is probably rhizomatous (I have not seen a mature stock), the stems branched in the upper part with somewhat spreading branches. Stems slender, terete, covered with spreading straight white hairs c. $0.25 \mathrm{~mm}$ long and long reddish tubercle-based setae $2-4 \mathrm{~mm}$ long and with occasional glandular-tipped hairs of intermediate length, the stems $0.3-0.7 \mathrm{~mm}$ broad in the flowering region, the branching usually alternate. Leaves mostly alternate but on some branches tending to be opposite or in whorls of 3 , the largest rarely more than $10 \mathrm{~mm}$ long on the main branches and as small as $1 \mathrm{~mm}$ on ultimate branches, ovate, usually broadly, to almost orbicular, the apex rounded or less frequently somewhat acute with a seta at the tip, the margins usually recurved and with long, tubercle-based reddish setae often giving the leaf a dentate appearance, the upper surface dark with straight, white, shining tubercle-based hairs, the lower surface paler than the upper with shining, white, straight hairs, the petiole distinct and often 1-2 mm long. Flowers occurring singly in the axils of upper leaves, the bracts c. $1 \mathrm{~mm}$ long, light or dark brown, linear and somewhat hairy. Peduncles 10-20 mm long, with slender, coloured, glandular-tipped hairs at least in the upper part, often also with some long dark-coloured setae and with short, straight, white, shining hairs, rarely glabrous, broadening in the upper part to form a receptacle $1-1.5 \mathrm{~mm}$ in diameter and angled in under the calyx-lobes. Calyx-segments 5, deciduous, tending to be pale and rather scarious, 2-3 mm long, elliptical to narrowly ovate, usually acute, with occasional white or glandular hairs or glabrous except on the inner surface which has fine curled hairs near the margin and straight hairs on the centre ridge, the base of each segment attached well inside the top of the receptacle and folded back over it with a thick ridge across the back above the edge of the receptacle. Petals 5 , dark pink with a dark patch at the base, $7-9 \mathrm{~mm}$ long and c. $\frac{1}{2}$ as wide, the widest part usually near the centre, elliptical, or almost diamondshaped, to linguiform, the edges strongly folded in the bud and with an undulate margin, deciduous. Stamens 10,4-4.5 mm long; filament $0.2-0.5 \mathrm{~mm}$ long, terete in the upper part, often joined with the other filament in front of the same petal; body of the anther expanding abruptly above the filament, often extending below at the back, $2 \mathrm{~mm}$ long and covered with minute tubercles, at the apex narrowed into the anther-tube; anther-tube tapering, tuberculate, 2-3 $\mathrm{mm}$ long and with a narrow orifice. Ovary covered with short, appressed, silky hairs, occasionally with a few glandular hairs; on a short broad base, the straight style $3 \mathrm{~mm}$ or more in length. Ovules 2, 1 in each loculus, suspended from the top angle of the central axis. Fruit obcordate to almost orbicular, turgid, $0.4 \mathrm{~cm}$ long and almost as wide, the axis unthickened. Seeds not seen at maturity, brown, with sparse fine hairs, with a piece of tissue near the base of the adaxial side, the appendage coiled towards the axis, with sparse fine hairs.

Distribution: In sandy forest soils of S. Western Australia. Map 4, see p. 167.

Specimens Examined: Western Australia: Eastern Warren District: near Mt Lindsay, Muir 1879 (MEL); track to summit, Mt Frankland, Scrymgeour 1180, 9.1966 (PERTH); on hills along the Frankland R, Maxwell (MEL); Willyung, Newby 1927, 11.1965 (PERTH); 4 
miles [7 km] W. of Denmark on Manjimup Road, Fairall 606, 10.1962 (PERTH); Parryville, 12 miles [19 km] W. of Denmark, Willis 9.1947 (MEL); Bow R, Jackson NSW 119596, 11.1912 (NSW); summit of Burrabomup, 12.1877 (MEL); near King Georges Sound, Maxwell (MEL); in arenosis sylvae ad sinum regis Georgii III, Preiss 1316, 10.1840 (MEL 1007872); Albany, Goadby (PERTH). Without precise locality: Western Australia, Drummond 46 (MEL).

F. Mueller, Fragm. 12: 7 (1882), includes this species in T. hirsuta. Blackall \& Grieve, Western Austral. Wildflowers: 260 (1954), key out a "T. setigera var. hispidissima" without author but there is no indication that it is based on this species which bears no close similarity to $T$. setigera.

This species has close affinity to $T$. hirsuta which is the only other species to bear extremely long, dark-coloured, tapering, tuberculate anther-tubes. It can usually be readily distinguished from $T$. hirsuta by its small broadly ovate to almost orbicular leaves and its straight stem-hairs.

\section{Tetratheca similis $J$. Thompson sp. nov.}

HoLotyPe: Darling Range, Western Australia, A. T. Hotchkiss and A. J. Eames 28.viii.1953 (NSW 125187).

Fruticulus usque ad $30 \mathrm{~cm}$ altus. Rami pilis tenuibus curvatis vel crispis et setis sparsis vestiti. Folia verticillata verticillis 3-foliatis plerumque 5-7 mm longa, ovata ad late ovata. Pedunculi plerumque c. $2 \mathrm{~cm}$ longi; receptaculo c. $1 \mathrm{~mm}$ diametro. Flores 4-meri. Stamina filamentis $0.25 \mathrm{~mm}$ longis; tubis antherarum latis c. $1-1 \cdot 5 \mathrm{~mm}$ longis. Ovarium dense pubescens; ovulis 2 .

A small shrub to $30 \mathrm{~cm}$ in height with numerous branches both at the base and at various points on the upper part of the plant, the stock much branched and slender, probably rhizomatous. Stems slender terete, somewhat vertically ridged or wrinkled, a little thicker below the nodes, with numerous, fine, white, curved or curled, usually retrorse, hairs, and scattered, long, broad-based, brown setae to $3 \mathrm{~mm}$ long, often bearing tubercles or apparently glandular dark hairs, the stems $0.3-0.6 \mathrm{~mm}$ broad in the flowering region, often with several branches arising at one point. Leaves in whorls of 3 , ovate to broadly ovate, usually 5-7 $\mathrm{mm}$ long, the upper surface dark, glabrous or with minute, rather stiff hairs, the lower much paler, glabrous, the tip incurved with a minute point, the margins 2- to many-lobed, flat or recurved but less recurved near marginal setae, narrowing at the base to a short petiole often bearing several long setae. Flowers occurring singly, perhaps occasionally several together, in the upper leaf-axils, the bracts $0.5-2 \mathrm{~mm}$ long, brown, broadly ovate to linear and with a few hairs. Peduncles dark-coloured, lengthening as the flower matures, usually c. $20 \mathrm{~mm}$ long in the mature flower, glabrous, thickened and rather strongly curved at the top and at the extreme top abruptly thickened into a receptacle c. $1 \mathrm{~mm}$ in diameter. Calyx-segments 4 , deciduous, very dark-coloured, $2.5-3 \mathrm{~mm}$ long, ovate-elliptical, acuminate, glabrous (except on the inner surface which has fine curled hairs especially near the margins and tip), each segment attached well inside the top of the receptacle with a ridge along the lower back and a large thickening in the centre of the lower back. Petals 4, dark pink with a tendency to be darker at the base, broadly linguiform, $7 \mathrm{~mm}$ long and $3 \mathrm{~mm}$ wide with the greatest width in the top $\frac{1}{3}$, deciduous. Stamens $8,3 \mathrm{~mm}$ long; filaments $0.25 \mathrm{~mm}$ long, body of the anther a little less than $2 \mathrm{~mm}$ long, somewhat tapering at the base and with minute hairs, at the apex tapering only gradually into the anther-tube; anther-tube broad, c. $1-1.5 \mathrm{~mm}$ long, scarcely curved. Ovary with a dense, short, somewhat silky pubescence; tapering to a style c. $2 \mathrm{~mm}$ long with short dense hairs at the base. Ovules 2, 1 in each loculus, each suspended from a swollen placenta on the upper half of the central axis. Fruit not seen.

Distribution: Little known, perhaps very restricted, in SW. Western Australia. Map 4, see p. 167.

Specimens Examined: Western Australia: Darling District: Darling Range, Hotchkiss \& Eames NSW 125187, 8.1953 (NSW); Brookton-Kelmscott road, 47 miles [76 km] peg, along 
track to "Warrawoona", Aplin 210, 9.1958 (PERTH); 50 miles $[80 \mathrm{~km}]$ from Perth towards Brookton, Wrigley 10.1968 (CBG 206862). Without precise locality: Western Australia, 20, 1879 (MEL 1008014).

This species bears a remarkable similarity in its vegetative parts to $T$. pilifera but its stamens have short filaments and narrow-based anthers with tapering smooth anther-tubes of moderate length. The stamens also serve to distinguish $T$. similis from $T$. hirsuta the only other species with which it could be confused.

\section{Tetratheca fasciculata $J$. Thompson sp. nov.}

Holotype: Sources of Blackwood R [Western Australia], Miss Cronin 1889 (MEL 1008329).

Fruticulus minus quam $20 \mathrm{~cm}$ altus. Rami pilis tenuibus patentibus et setis sparsis vestiti. Folia alterna vel irregulariter opposita, plerumque $3-5 \mathrm{~mm}$ longa, ovato-elliptica. Pedunculi plerumque $7-12 \mathrm{~mm}$ longi; receptaculo $1.5 \mathrm{~mm}$ diametro. Flores 4-meri. Stamina filamentis $0.25-0.5 \mathrm{~mm}$ longis; tubis antherarum attenuatis, $1.25 \mathrm{~mm}$ longis. Ovarium dense pubescens; ovulis 2 .

A compact shrub less than $20 \mathrm{~cm}$ in height with numerous stems arising from the top of a very stout woody stock with no definite evidence of a rhizome, the stems branching infrequently. Stems slender, terete, covered with spreading, fine, white hairs, dense on younger branches, the older branches glabrous, with a few long, tubercle-based brown setae $2 \mathrm{~mm}$ or more in length especially at the nodes, the stems $0.4-0.6 \mathrm{~mm}$ broad in the flowering region, the branches alternate but occasionally several arising together. Leaves alternate or somewhat irregularly opposite and appearing to be somewhat deciduous, usually $3-5 \mathrm{~mm}$ long, ovate-elliptical, the margins slightly recurved to revolute, the apex obtuse and blunt, the upper surface covered with rather dense, short, spreading, curved, antrorse hairs, the lower much paler with hairs on the midrib, the petiole distinct with a tubercle-based seta on each side of its base. Flowers occurring singly in the leaf-axil, the bracts c. 1-2 mm long, ovate to obovate, brown or becoming green and leaf-like and with spreading hairs. Peduncles usually 7-12 mm long, somewhat dark-coloured, glabrous or with a few spreading, rather stiff, fine, white hairs, thickened and somewhat hooked in the upper part and widening at the extreme top to form a receptacle $1.5 \mathrm{~mm}$ in diameter, the receptacle bearing scattered stout dark setae to $1 \mathrm{~mm}$ in length with large bases and a tendency to have small glandular tips. Calyx-segments 4, deciduous, ovate, acute to acuminate, $2 \mathrm{~mm}$ long, dark-coloured, with very broad-based dark hairs c. $0.5 \mathrm{~mm}$ long with small glandular tips, the inner surface with a fringe of hairs near the top, the segments not conspicuously thickened at the base except for a small area in the centre but attached inside the top of the receptacle. Petals 4, dark pink, linguiform, 6-8 mm long and c. $\frac{1}{2}$ as wide with the greatest width above the centre, deciduous. Stamens 8 , $3 \mathrm{~mm}$ long; filament $0.25-0.5 \mathrm{~mm}$ long; body of the anther expanding rather abruptly above the filament especially at the back, $1.5 \mathrm{~mm}$ long, somewhat curved, narrowed at the apex into the anther-tube; anther-tube tapering, $1.25 \mathrm{~mm}$ long with a rather narrow oblique orifice. Ovary with a very short, dense pubescence; tapering at the apex into a slender style $2 \mathrm{~mm}$ long. Ovules 2,1 in each loculus, each suspended from a swollen placenta on the upper part of the axis. Fruit not seen.

Distribution: Little known, in SW. Western Australia. Map 4, see Page 167.

Specimens Examined: Western Australia: Stirling District: near Lake Wagin, Cronin 1895 (MEL); sources of Blackwood R, Cronin 1889 (MEL 1008329).

The habit of this species with so many slender stems arising at the top of a stock resembling a taproot renders it distinct. The affinities of $T$. fasciculata are obscure but it could have some relationship to $T$. setigera.

14. Tetratheca virgata Steetz in Lehmann, Pl. Preiss. 1: 212 (1845); Walpers, Repert. Bot. Syst. 5: 68 (1845); Steetz, Familie Tremandreen: 10 (1853); Schuchardt, Syn. Tremandr.: 20 (1853); Bentham, Fl. Austral. 1: 133 (1863); F. Mueller, Fragm. 
12: 5 (1882) including T. nuda var. spartea; F. Mueller, Syst. Census Austral. Pl. $1: 9$ (1882); F. Mueller, Second Syst. Census 1: 15 (1889); Gardner, Enum. P1. Austral. Occ.: 71 (1930); Blackall \& Grieve, Western Austral. Wildflowers 1: 260 (1954); Beard, W. Austral. Pl.: 56 (1965).

HolotyPE: In limoso-calculosis inter frutices planitiei haud longe a praedio rustico Domini Brockmann (York) in Nova Hollandia occidentali, Preiss 1332 in part, 15.x.1839 (MEL 1008114).

SyNONYMY: Tetratheca virgata var. setigera Steetz in Lehmann, Pl. Preiss. 1: 213 (1845); Walpers, Repert. Bot. Syst. 5: 68 (1845); Schuchardt, Syn. Tremandr.: 21 (1853); Bentham, Fl. Austral. 1: 133 (1863); F. Mueller, Fragm. 12: 5 (1882). HolotyPe: In Nova Hollandia meridionali occidentali, Preiss (? an Drummond ?), Preiss 1333 (MEL 1008115).

A small often sparsely leaved shrub to $40 \mathrm{~cm}$ in height with slender stems branching near and above a woody stock. Stems terete with numerous or, more frequently, scattered light brown setae to $3 \mathrm{~mm}$ in length, with or without swollen bases, sometimes, but not always, the setae strongly retrorse, the stems $0.5-1 \cdot 1 \mathrm{~mm}$ broad in the flowering region, the branching alternate and usually at an acute angle. Leaves alternate, up to $1 \mathrm{~cm}$ but usually only $2-3 \mathrm{~mm}$ in length, narrow-linear to narrowly ovate or elliptical, the apex tipped with a few tiny hairs, the margins revolute or rarely flat, both surfaces glabrous or almost so, the petiole short; the leaves often deciduous, the older branches bearing only the bases of the petioles. Flowers occurring singly in the leaf-axils, the bracts $0.5-1 \mathrm{~mm}$ long, light brown, narrowlinear and with hairs on the upper part of the tip. Peduncles 6-12 mm long, usually dark-coloured, slender, glabrous, broadening and angled in the upper part and broadening again at the top to form a receptacle c. $1 \mathrm{~mm}$ in diameter. Calyxsegments 4 , rarely 5 , deciduous, usually dark-coloured, $1.5-2.5 \mathrm{~mm}$ long, broadly to narrowly ovate, acute to acuminate, glabrous except on the inner surface which has a few hairs near the margins and apex, the base of each segment attached inside the top of the receptacle and folded back over it with a conspicuous ridge across the lower back above the edge of the receptacle and a large thickening in the centre of the ridge. Petals 4, rarely 5, dark pink with a dark patch at the base, obovate to broadly linguiform, $6 \cdot 5-10 \mathrm{~mm}$ long and usually more than $\frac{1}{2}$ as wide with the widest part in the upper $\frac{1}{2}$, deciduous. Stamens usually 8 , occasionally $10,4 \cdot 5(-5) \mathrm{mm}$ long, the filament broad, c. $1 \mathrm{~mm}$ long, at an angle to the body of the anther, occasionally joined at the extreme base to the other filament opposite the same petal, the body of the anther $2 \mathrm{~mm}$ long, purple, shining and smooth or somewhat tuberculate, somewhat curved with a broad base extending behind the filament, at the apex suddenly contracting into the anther-tube; anther-tube yellow or purple-tinged, often somewhat swollen near the base and often tuberculate, $2 \mathrm{~mm}$ long with an oblique and often broad orifice (fig. 4). Ovary glabrous, with or without a short broad base, the slender and somewhat twisted style $2 \cdot 5(-3) \mathrm{mm}$ long. Ovules 2,1 in each loculus, attached to conspicuous thickenings on the upper part of the central axis. Fruit not seen.

Distribution: In sandy and gravelly soil in SW. Western Australia. Map 5, see p. 174.

Specimens Examined (Selection Only): Western Australia: Eastern Darling and Western Avon District: Road beyond Morses, 10 miles [16 km] from York, Sargent 602, 10.1907 (PERTH); in limoso-calculosis inter frutices planitiei haud longe a praedio rustico Domini Brockman (York), Preiss 1332 in part, 10.1839 (MEL 1008114); between Swan R and King Georges Sound, Forrest 1881 (MEL); in Nova Hollandia meridionalis occidentalis, Preiss 1333 (MEL 1008115); Pingelly, Gardner 1021, 10.1920 (PERTH) ; 39.4 ml [62 km] from Collie towards Williams, Canning 3765, 10.1968 (NSW). Eastern Warren and Western Stirling District: 71 miles [114 km] from Perth towards Williams, Canning 9.1968 (CBG 030683); 13 miles [21 km] from Narrogin towards Wagin, Phillips 10.1968 (CBG 030429); sources of Blackwood R, Cronin 1890 (MEL); sources of Pallinup R, Cronin 1887 (MEL); 20 miles [32 km] from Katanning, Scott NSW 114880, 1936 (NSW); 60 miles [96 km] NW. of Albany, Stauffer 5358 \& Royce, 11.1963 (AD, CANB, MEL, NSW, PERTH); Mt Barker, Goadby 113, 10.1900 (PERTH); Kalgan R, Oldfield 198 (MEL); near King Georges Sound, Maxwell (MEL). Without precise locality: Western Australia, Walter (NSW 125094); Western Australia, Drummond 99 (MEL 1008120, 1008127).

This species has been confused in herbaria with $T$. nuda but can be readily distinguished from the latter by its long anther-tubes. The shape of its anthers distinguishes $T$. virgata from all other species. It seems to bear a relationship to $T$. retrorsa but differs in its dimensions, long broad filaments and ovule-number. 


\section{MAP 5 \\ - T. PARVIFOLIA \\ O T. ELLIPTICA \\ $\triangle T$. VIRGATA \\ $\triangle T$. DELTOIDEA \\ $\square$ T. PUBESCENS \\ - T. REMOTA}

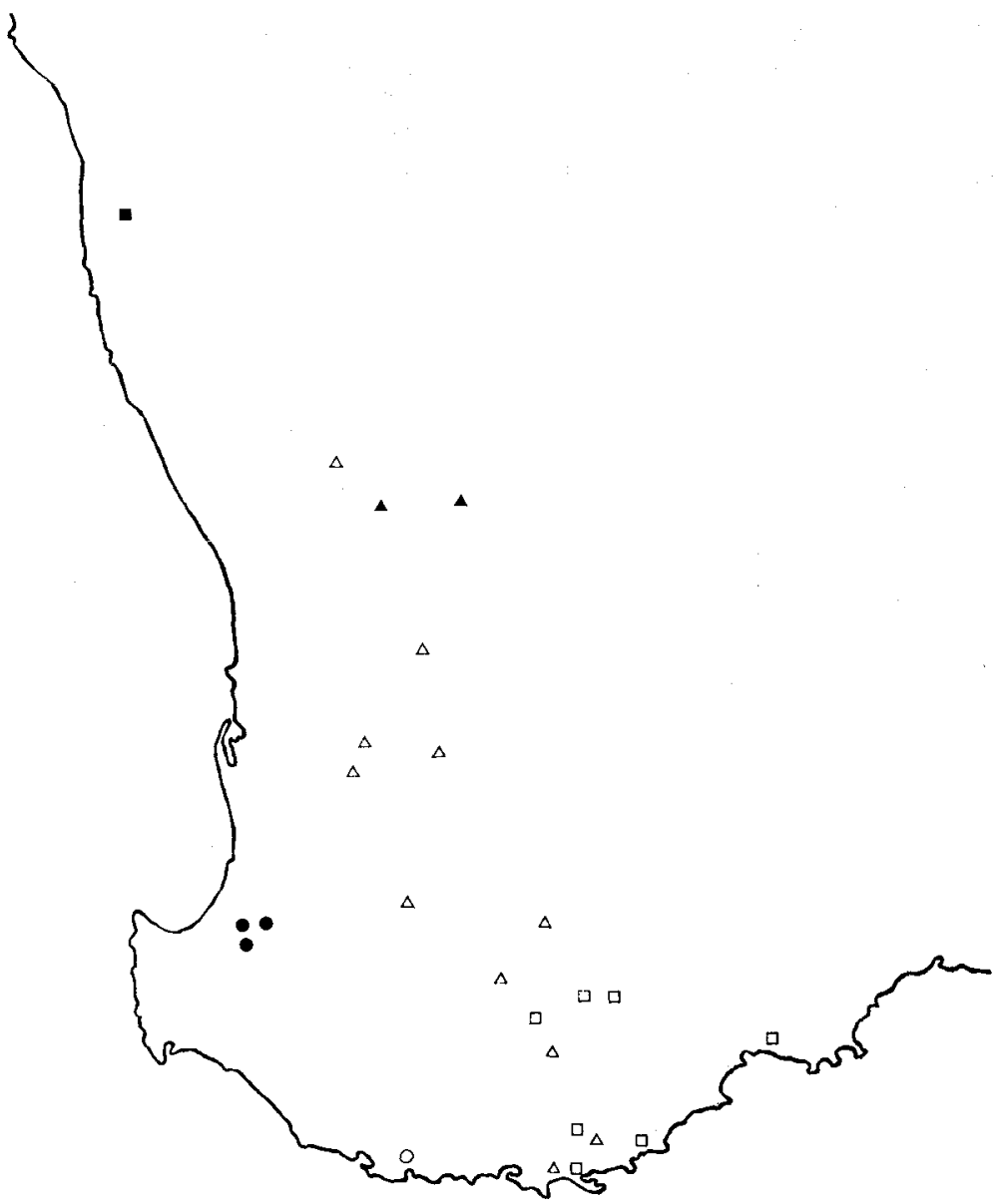

15. Tetratheca remota $J$. Thompson sp. nov.

Holotype: Mount Lesueur, C. A. Gardner 9362, 21.viii.1949 (PERTH).

Fruticulus usque ad $40 \mathrm{~cm}$ altus. Rami glabri sed dense tuberculis parvis vestiti. Folia alterna vel aliquot opposita, usque ad fere $20 \mathrm{~mm}$ longa, apparenter anguste linearia. Pedunculi usque ad $20 \mathrm{~mm}$ longi; receptaculo usque ad $1 \mathrm{~mm}$ diametro. Flores 5-meri. Stamina filamentis usque ad $0.5 \mathrm{~mm}$ longis; tubis antherarum flavis, 1.5-2 mm longis. Ovarium glabrum; ovulis 2 .

A small often sparsely-leaved shrub to $40 \mathrm{~cm}$ in height with slender stems branching near or above a slender woody stock. Stems slender, terete, glabrous and densely covered with minute tubercles; $0 \cdot 3-1.0 \mathrm{~mm}$ wide in the flowering region, the branching alternate and at an acute angle. Leaves alternate or occasionally a few upper ones opposite, to almost $2 \mathrm{~cm}$ in length but usually shorter, appearing narrow-linear owing to the usually revolute margins, both surfaces glabrous or the upper part with a few stiff hairs especially near the rather obtuse apex, the base of the blade broad, less revolute and somewhat cordate, the petiole distinct; the leaves appearing to be somewhat deciduous on the lower part of the plant. Flowers occurring singly in leaf-axils, the bracts apparently absent. Peduncles to $20 \mathrm{~mm}$ long, glabrous but minutely tuberculate on the upper part, very slender, broadening suddenly in the upper part to a somewhat lobed receptacle $1 \mathrm{~mm}$ or less in diameter. Calyx-segments 5, dark-coloured, deciduous, broadly elliptical to ovate, acute or obtuse, glabrous except on the inner surface, with hairs especially near the margin, the base of each attached inside the top of the receptacle and curved back over it and with a thick central boss fitting into a more deeply recessed part of the receptacle. 
Petals 5, dark pink with a dark patch at the extreme base, obovate to linguiform, 6-7 $\mathrm{mm}$ long and c. $\frac{1}{2}$ or less in width, the greatest width above the centre, deciduous. Stamens usually 10,3-4 mm long; filament slender and somewhat hairy, to c. 0.5 $\mathrm{mm}$ long, at an angle to the body of the anther; body of the anther $2 \mathrm{~mm}$ long, purple, shining and smooth, with a broad base extending behind the filament, gradually contracting into the anther-tube; anther-tube yellow, 1.5-2 $\mathrm{mm}$ long with a broad almost straight orifice. Ovary glabrous, with a broad base, the slender style $3 \mathrm{~mm}$ long. Ovules 2, 1 in each loculus, attached below the top of the central axis. Fruit not seen.

Distribution: Known only from the Type specimen from the South Irwin district of SW. Western Australia. Map 5, see p. 174.

Specimens Examined: Western Australia: South Irwin District: Mt Lesueur, Gardner 9362, 8.1949 (PERTH). Without precise locality: Western Australia, Drummond (MEL 1008126, 1008128, 1008355).

This species seems to be related to $T$. virgata and perhaps $T$. deltoidea but differs in having slender filaments. From $T$. deltoidea it also differs in its long anther-tubes.

\section{Tetratheca deltoidea $J$. Thompson sp. nov.}

Holotype: Near Mt Caroline [Western Australia], Miss G. Sewell 1889 (MEL 1008321).

Habitus incognitus. Ramis setis retrorsis vestiti. Folia alterna vel opposita, usque ad $13 \mathrm{~mm}$ longa, late cordato-ovata ad angustate deltoidea. Pedunculi 13-20 mm longi; receptaculo 1-2 mm diametro. Flores 5-meri. Stamina filamentis nullis; tubis antherarum latis rectis, c. $0.5 \mathrm{~mm}$ longis. Ovarium glabrum; ovulis 2.

Habit unknown. Stems terete, slightly vertically ridged on younger stems, with reddish brown, tubercle-based, strongly retrorse, appressed setae 1-2 $\mathrm{mm}$ long, the stems $0.5-1.0 \mathrm{~mm}$ broad in the flowering region, the branching alternate. Leaves alternate or opposite, to $13 \mathrm{~mm}$ in length but some as small as $3 \mathrm{~mm}$, broadly cordateovate to deltoid or narrowly deltoid, glabrous, the under surface paler, the midrib conspicuous at the base, the margins flat with minute denticulations, or tending to recurve, usually with sparse inconspicuous point- or even seta-bearing teeth at least at the base, the apex with a small sharp point, pale, usually $0.5 \mathrm{~mm}$ in length; often with strongly reversed setae below the base, the petiole distinct. Flowers occurring singly in the leaf-axils, the bracts $1.5 \mathrm{~mm}$ long, green and leaf-like and glabrous. Peduncles 13-20 mm long, slender, glabrous, dark-coloured, curved at the top and widening to form a receptacle 1-2 $\mathrm{mm}$ in diameter. Calyx-segments 5, deciduous, dark-coloured, glabrous except for hairs on the inner margin, c. $2 \mathrm{~mm}$ long, ovate to almost deltoid, acuminate, rather thin in texture and undulate at the edges, each segment attached well inside the edge of the receptacle with a thick turgid ridge along the lower back. Petals 5, dark pink, broadly linguiform, c. $1 \mathrm{~cm}$ long and $7 \mathrm{~mm}$ wide with the greatest width in the top $\frac{1}{3}$, deciduous. Stamens 10 , $2.5 \mathrm{~mm}$ long, filament completely absent; body of the anther $2 \mathrm{~mm}$ long, narrowed at the base with the narrowed basal part at a slight angle, the rest straight, very slightly narrowed to a broad straight anther-tube; anther-tube c. $0.5 \mathrm{~mm}$ long with a broad, straight, scarcely lipped orifice. Ovary glabrous, on a broad base and tapering at the apex into a rather stout glabrous style $1.5 \mathrm{~mm}$ long. Ovules 2,1 in each loculus, attached near the upper part of the central axis. Fruit not seen. p. 174.

Distribution: Apparently very restricted in inland SW. Western Australia. Map 5, see

Specimens Examined: Western Australia: Avon District: Mt Carol, Sewell 1889 (MEL); near Mt Caroline, Sewell 1889 (MEL 1008321); E. York, Sewell 1891 (MEL).

The location given for these specimens does not exclude the possibility that all are from the same site. In spite of the fragmentary nature of all the specimens this species is quite distinct and does not seem to bear a close relationship to any other. Similar retrorse stem-hairs can be found in $T$. virgata but the anthers of that species are quite different. 


\section{Tetratheca parvifolia $J$. Thompson sp. nov.}

Holotype: Upper Capel, Western Australia, P. H. Sargent, 28.x.1921 (PERTH).

Fruticulus $20-30 \mathrm{~cm}$ altus. Rami multituberculati, pilis minutis tenuibus albis curvatis et setis sparsis antrorsis vestiti. Folia plerumque alterna, plerumque 3-4 mm longa, ovata ad elliptica vel linearia. Pedunculi 6-15 mm longi; receptaculo minus quam $1 \mathrm{~mm}$ diametro. Flores 5-meri. Stamina filamentis plerumque minus quam $0.25 \mathrm{~mm}$ longis; tubis antherarum vix attenuatis, usque ad $1 \mathrm{~mm}$ longis. Ovarium glabrum; ovulis 2 .

A small shrub $20-30 \mathrm{~cm}$ in height (from specimens seen), the stems branching frequently near or well above a woody stock. Stems slender, terete or somewhat vertically ridged with numerous small tubercles, minute, fine, white, curved hairs and scattered antrorse setae $2 \mathrm{~mm}$ or more in length with large tubercular bases and often with dark protuberances or even apparently branched hairs on them, the setae more frequent below the nodes and on young growth, the stems $0.4-0.8 \mathrm{~mm}$ broad in the flowering region, the branching alternate. Leaves alternate, infrequently subopposite or tending to be in whorls of 3 , usually $3-4 \mathrm{~mm}$ long, ovate to elliptical or linear, the margins recurved or revolute, the apex lacking a point or with a blunt inconspicuous point, the upper surface shining and with numerous short, stiff, slightly antrorse hairs, especially near the margins and apex, and occasional setae near the margin, the lower surface glabrous with a broad midrib, the petiole conspicuous, c. $0.5 \mathrm{~mm}$ long, lacking setae but usually with setae with large tubercular bases on either side. Flowers occurring singly in the axils of upper leaves, the bracts 0.5-1 mm long, variable, often tending to be rather broad-elliptical and green and leaf-like with hairs especially on the upper surface. Peduncles 6-15 mm long, very slender, with short, fine, spreading hairs or glabrous, curved at the top, broadening very sharply at the extreme top to form a receptacle less than $1 \mathrm{~mm}$ in diameter, the receptacle occasionally bearing very stout setae, c. $1 \mathrm{~mm}$ long with a small glandular tip, on the margin. Calyx-segments 5, deciduous, dark-coloured, $1.5 \mathrm{~mm}$ long, ovate, acuminate, though sometimes only shortly so, with a few tubercle-based very stout dark or pale setae c. $1 \mathrm{~mm}$ long with slender necks and small glandular tips, the inner surface with a dense fringe of hairs inside the margin and tip, the base of each segment attached inside the top of the receptacle and curved back over it with a ridge along the lower back and a large basal thickening. Petals 5, dark pink, broadly linguiform, very narrow at the base, $6-7 \mathrm{~mm}$ long and c. $\frac{1}{2}$ as wide with the greatest width in the top $\frac{1}{2}$, deciduous. Stamens usually $10,2.5 \mathrm{~mm}$ or less in length; filament very short, less than $0.25 \mathrm{~mm}$ in length and somewhat terete, distinct from the body of the anther; body of the anther rather broad-based, c. $1.25 \mathrm{~mm}$ long; anther-tube scarcely tapering, $1 \mathrm{~mm}$ or less in length, with a broad, scarcely 2-lipped orifice. Ovary glabrous, tapering to a style $1.5 \mathrm{~mm}$ long. Ovules 2, 1 in each loculus, suspended at or near the top of the central axis. Fruit not seen.

Distribution: In open forest in SW. Western Australia. Map 5, see p. 174.

Specimens Examined: Western Australia: North Western Warren District: Lowden, Preston R, Koch 2585, 1.1914 (MEL); 2 S. of Donnybrook, Vasek 681010-39, 10.1968 (CANB); Upper Capel, Sargent 10.1921 (PERTH); Blackwood R, McHard 1891 (MEL).

$T$. parvifolia is very small in all its parts and does not seem to bear a close relationship to any other species.

18. Tetratheca pubescens Turcz. in Bull. Soc. Imper. Nat. Moscou 25 (2): 141 (1852); Bentham, Fl. Austral. 1: 135 (1863).

Holotype: Nova Hollandia, Drummond, coll. $v, n .245$. I have not seen this specimen but MEL 1007978 is probably an Isotype.

Synonymy: Tetratheca tenuiramea Turcz. in Bull. Soc. Imper. Nat. Moscou 25 (2): 142 (1852). Holotype: Nova Hollandia, Drummond, coll, iii, $n$. 209. I have not seen this specimen but MEL 1007983 is probably an Isotype. 
Tetratheca setigera var. montana Pritzel in Diels \& Pritzel in Bot. Jahrb. Syst. 35 : 330 (1904). HolotYPE: In glareosis montium Stirling range, flor. m. Oct. $(D 4269)$. I have not seen this specimen but from the description given there can be no doubt as to its identity.

Tetratheca montana (Pritzel) J. S. Beard, W. Austral. Pl.: 56 (1965), 'montana E. Pritzel Sm', nomen invalidum, based on Tetratheca setigera var. montana Pritzel.

A small shrub to $60 \mathrm{~cm}$ in height with numerous rather slender stems arising from a slender branched stock, the stems much-branched both near and well above the stock. Stems terete and rather irregularly longitudinally ridged, covered with minute tubercles and usually with spreading, rarely somewhat retrorse, short, white, straight or occasionally curved hairs; most specimens with at least some long palebrown setae 1 or even $1.5 \mathrm{~mm}$ long or perhaps only their swollen bases, the stems $0.5-1.0 \mathrm{~mm}$ broad in the flowering region, the branches alternate, or several arising together and often at an acute angle. Leaves in regular or irregular whorls of 3 or alternate, rarely a few opposite near the base of branches, to $10 \mathrm{~mm}$ in length but usually shorter, generally broadly ovate but usually with 2-4 lobes tipped by tubercles and often bearing setae, the margins loosely revolute or occasionally almost flat, the apex with a blunt point, the upper surface darker than the lower, covered with dense erect hairs, rarely lacking in the centre, the lower surface almost glabrous with a conspicuous lower midrib usually bearing hairs, the petiole distinct, usually bearing long setae with very stout bases; on some branches the leaves reduced and sparse. Flowers occurring singly in the axils of upper leaves, the bracts less than 1 $\mathrm{mm}$ long, obovate and pubescent. Peduncles slender, glabrous, 6-15 mm long, expanding widely at the top to form a receptacle $1-1.5 \mathrm{~mm}$ in diameter, often curved just below the expanded part. Calyx-segments 5, deciduous, dark-coloured, usually $2 \mathrm{~mm}$ long, glabrous except on the inner surface which has a few hairs, usually obtuse, occasionally somewhat acute, elliptical, rarely somewhat broader near the top of the receptacle and folded back over it with a conspicuous thickened ridge across the lower back. Petals 5, dark pink or occasionally white, broadly to narrowly linguiform, 9-11 mm long and less than $\frac{1}{2}$ as wide with the greatest width in the upper $\frac{1}{3}$, deciduous. Stamens $10,(2 \cdot 5-) 3 \cdot 5-4 \mathrm{~mm}$ long; filament very short, less than $0 \cdot 25$ $\mathrm{mm}$ long; body of the anther (1.5-) $2-2.5 \mathrm{~mm}$ long, the lower $0.25 \mathrm{~mm}$ flattened and usually at an angle to the upper, the upper part merging into the anther-tube; anthertube (1-) 1.5-2 mm long, rarely shorter, slightly curved, and tapering gradually to a rather broad, scarcely oblique orifice. Ovary glabrous, on a short broad base, the top tapering gradually to a rather thick glabrous style less than $2-2.5 \mathrm{~mm}$ long. Ovules 2 , 1 in each loculus, attached above the centre of the axis. Fruit obovate, $5 \mathrm{~mm}$ long and $4 \mathrm{~mm}$ wide, glabrous. Seeds not seen.

Distribution: In light soils on hillsides, perhaps in shade, often in gullies and on creekbanks, in S. Western Australia especially the Stirling Ranges. Map 5, see p. 174.

Specimens Examined (Selection Only): Western Australia: South Stirling District and South Eastern Warren District: Stirling Range, Ashby 104, 9.1946 (PERTH); Red Gum Springs, Stirling Range National Park, Wrigley 10.1968 (CBG 027215, 027217, AD, BRI, MEL, NSW); 2 miles [3 km] N. of Red Gum Pass, Briggs NSW 125184, 10.1960 (NSW); near Chester Pass, Phillips 10.1962 (CBG 009977, 019321, 010030, NSW); Gold Hole, Stirling Ranges, Newbey 852, 8.1963 (PERTH); $1 \mathrm{~km} \mathrm{~N}$. of base of Bluff Knoll, Wilson 4176, 9.1966 (PERTH, NSW); Monjerrup, Stirling Range (MEL); on Cranbrook road, Ashby 548, 10.1963 (AD); Bremer R, $W e b b 1884$ (MEL); Napier Creek, S. of Porongerup Ranges, Andrews 10.1903 (PERTH); Mt Many Peaks, Pfeiffer 19 (PERTH); near Mt Many Peaks, Ashby 642, 10.1963 (AD); towards King Georges Sound, Webb 109, 1880 (MEL); Albany, Galbraith (MEL). Without precise locality: Western Australia, Drummond 245 (MEL 1007978); Western Australia, Drummond 209 (MEL 1007983).

F. Mueller, Fragm. 12: 8 (1882), includes this species in T. setigera and Gardner, Enum. Pl. Austral. Occ.: 71 (193), includes it in T. hirsuta, 'viminea'. The specimen cited by Diels and Pritzel in Bot. Jahrb. Syst. 35: 330 (1904) is T. hirsuta.

The lobed pubescent leaves, often arranged in whorls of 3 , serve to distinguish this species from all others. 


\section{Tetratheca elliptica $J$. Thompson sp. nov.}

HolotYPE: Bow River, South-Western Australia, S.W. Jackson 10.1912 (NSW 125189).

Fruticulus usque ad $60 \mathrm{~cm}$ altus. Rami pilis tenuibus patentibus vel curvatis et setis sparsis vestiti. Folia alterna, plerumque $8-10 \mathrm{~mm}$ longa, ovato-elliptica ad suboblonga. Pedunculi usque ad $6 \mathrm{~mm}$ longi; receptaculo $1 \cdot 5-2 \mathrm{~mm}$ diametro. Flores 5-meri. Stamina filamentis minus quam $0.25 \mathrm{~mm}$ longis; tubis antherarum subcurvis, $1 \mathrm{~mm}$ longis. Ovarium glabrum; ovulis 2 .

A small shrub to $60 \mathrm{~cm}$ in height, sparsely branched at intervals along the stem, the basal parts not seen. Stems stout, terete, somewhat longitudinally ridged on younger branches, covered with small tubercles and rather sparse, fine, white, spreading or somewhat curved, mostly retrorse hairs to $5 \mathrm{~mm}$ in length and with occasional long, pale-brown, tubercle-based setae to $2 \mathrm{~mm}$ in length, especially at the thickened nodes, the setae dense and reddish-coloured on young growth, the stems $0.8-1.0 \mathrm{~mm}$ broad in the flowering region, the branching alternate and at an acute angle. Leaves alternate, mostly $8-10 \mathrm{~mm}$ long, ovate-elliptical to almost oblong, obtuse, the upper surface with short stiff hairs especially near the margin and an occasional tubercle near the margin, the lower surface glabrous, the margins recurved or occasionally flat, the petiole very short but distinct. Flowers occurring singly or 2 together in the axils of upper leaves, the bracts $0.5-1 \mathrm{~mm}$ long, brown, linear to broadly ovate or lanceolate, with hairs on the upper and usually on the lower surface. Peduncles $6 \mathrm{~mm}$ or less in length, dark-coloured, glabrous, curved and broadening at the top to a receptacle $1.5-2 \mathrm{~mm}$ in diameter. Calyx-segments 5 , deciduous, dark-coloured, $2-2.5 \mathrm{~mm}$ long, elliptical, acute to almost obtuse, glabrous except on the inner surface which has shining white hairs, the base of each segment attached well inside the top of the receptacle, with a thickened ridge on the lower back above the edge of the receptacle. Petals 5, dark pink, broadly linguiform, 8-9 $\mathrm{mm}$ long and c. $\frac{1}{2}$ as wide with the greatest width near the apex, deciduous. Stamens $10,2.5-3 \mathrm{~mm}$ long; filament very short, less than $0.25 \mathrm{~mm}$ in length; body of the anther $1.5 \mathrm{~mm}$ long, narrowed and slightly angled at the base, glabrous and slightly curved, at the apex tapering rather abruptly to the anther-tube; anther-tube slightly curved, c. $1 \mathrm{~mm}$ long, the orifice oblique and rather narrow. Ovary glabrous, but with some hairs on the inner surface, tapering to a rather slender style $1.5 \mathrm{~mm}$ long. Ovules 2, 1 in each loculus, attached near the centre of the axis (fig. 5). Fruit not seen in mature condition but apparently turgid, $6 \mathrm{~mm}$ long. Seeds $3.5 \mathrm{~mm}$ long, elongate-ovoid, rounded at the base, truncate at the apex, flattened and somewhat winged, perhaps with the placenta, on the adaxial surface, with a few somewhat appressed fine hairs on the upper part, the appendage dark cream with very fine hairs, curving towards the adaxial side but the coils all compressed beyond the seed.

Distribution: Known only from the Type specimen, 'mostly on sandy ground', SW. Western Australia. Map 5, see p. 174.

Specimens Examined: Western Australia: Warren District: Bow R, Jackson NSW 125189, 10.1912 (NSW).

In general aspect this species resembles $T$. setigera, a species to which it is probably closely related, but the short peduncles terminating in broad receptacles as well as the shorter stamens serve to distinguish it.

20. Tetratheca setigera Endl. in Huegel, Enum. Pl.: 8 (1837); Steudel, Nomencl. Bot. [ed. 2] 2: 673 (1841); Walpers, Repert. Bot. Syst. 1: 249 (1842); Steetz in Lehmann, Pl. Preiss. 1: 214 (1845); Walpers, Repert. Bot. Syst. 5: 68 (1845); A. Gray in Hooker's J. Bot. Kew Gard. Misc. 4: 200 (1852); Steetz, Familie Tremandreen: 10 (1853); Schuchardt, Syn. Tremandr.: 39 (1853); Bentham, Fl. Austral. 1: 133 (1863); F. Mueller, Fragm. 12: 8 (1882) incl. T. pubescens; F. Mueller, Syst. Census Austral. P1. 1: 9 (1882); F. Mueller, Second Syst. Census 1: 
15 (1889); Diels \& Pritzel in Bot. Jahrb. Syst. 35: 330 (1904); Gardner, Enum. Pl. Austral. Occ.: 71 (1930); Blackall \& Grieve, Western Austral. Wildflowers 1: 260 (1954); Beard, W. Austral. Pl.: 56 (1965).

HoLotYPE: King Georges Sound [Western Australia], (Hügel), not examined. I have seen the Preiss specimen, 1326 (MEL 1007979), which was compared (as noted on the sheet) with Hügel's specimen by Steetz.

Synonymy: Tetratheca setigera var. elongata Steetz in Lehmann, Pl. Preiss. 1: 215 (1845); Walpers, Repert. Bot. Syst. 5: 68 (1845); Turczaninow in Bull. Soc. Imper. Nat. Moscou 25: 141 (1852) 'T. strigosae' var. elongata; Steetz, Familie Tremandreen: 10 (1853). HoLOTYPE: In subarenosis sylvae ad fluvium "Canning River "(Perth) in Nova Hollandia occidentali, Preiss 1322, 9.1841 (MEL 1007980, 1007981, 1007982).

Tetratheca elongata (Steetz) Schuchardt, Syn. Tremandr.: 38 (1853) but, apparently by an unfortunate error, he refers to the basionym as 'Tetrathec. setigera Lindl. $\beta$ setigera Steetz'. HOLOTYPE: As for T. setigera var. elongata.

An erect or diffuse shrub to $60 \mathrm{~cm}$ in height with numerous stems arising from a branched woody stock and branching in the upper part. Stems terete, usually covered with well-separated brown setae to $2.5 \mathrm{~mm}$ in length with swollen bases and often with fine, white, curved or curled, spreading hairs between them (fig. 1), the setae usually much more dense and reddish-coloured on young growth, the stems $0.5-1.2 \mathrm{~mm}$ broad in the flowering region, the branching alternate but occasionally with several branches arising together. Leaves alternate, rarely a few opposite, broadly elliptical to linear, occasionally a little wider above or below the centre, from less than $5 \mathrm{~mm}$ to more than $20 \mathrm{~mm}$ in length, the apex incurved, with a short spiny point, the margins recurved or revolute and somewhat undulate or almost dentate owing to long, stiff, broad-based, coloured setae, or at least their bases, on the outer part of the upper surface, the upper surface dark, coriaceous, with scattered, short, white, stiff, usually curved hairs especially on the midrib, the lower surface paler with stiff hairs especially on the midrib or almost glabrous, the petiole short. Flowers occurring singly in the axils of upper leaves, the bracts c. $1 \mathrm{~mm}$ long, linear, dark brown and hairy at least on the upper surface. Peduncles 5-18 $\mathrm{mm}$ long, usually dark-coloured, glabrous or with a few to many stiff, broad-based, coloured antrorse setae to 1.5 or $2 \mathrm{~mm}$ in length, occasionally with a small glandular tip, on the upper part, the peduncle thickened and often angled in the upper part to form a receptacle $1.5 \mathrm{~mm}$ in diameter. Calyx-segments usually 5, deciduous, usually dark-coloured, $2.5-3.5 \mathrm{~mm}$ long, elliptical, obtuse or acute, glabrous or with broad-based setae to 1.5 or even $2 \mathrm{~mm}$ in length and sometimes with a small glandular tip, and with at least a few hairs on the inner surface near the margin, the thick base of each segment attached well inside the edge of the receptacle and folded back over it with a very thick, turgid ridge across the lower back. Petals 5, dark pink, broadly linguiform or obovate, rarely narrowly linguiform, $8-12 \mathrm{~mm}$ long and usually $\frac{1}{2}$ or less than $\frac{1}{2}$ as wide with the greatest width above the centre, usually in the upper $\frac{1}{3}$, deciduous. Stamens usually $10,3-4 \mathrm{~mm}$ long; filament short, c. $0.25 \mathrm{~mm}$ in length, and flattened and merging into the lower curved body of the anther; the body of the anther $c$. $1.5(-2) \mathrm{mm}$, dark purple to reddish brown, shining and smooth, occasionally with a few hairs, abruptly or gradually contracting into the anther-tube; anther-tube narrow, often yellow, c. $1.5 \mathrm{~mm}$ long but occasionally shorter, with a slightly oblique orifice. Ovary glabrous, or with a few hairs near the apex and hairs on the inner surface, on a conspicuous, very swollen, spongy, translucent base and tapering at the apex to a rather thick, glabrous style $1 \cdot 5-2 \mathrm{~mm}$ long. Ovules 2,1 in each loculus, attached to the upper part or centre of the central axis at a conspicuous swollen placenta apparently covered with minute shining hairs (fig. 5). Fruit not seen in mature condition.

Distribution: In sclerophyll scrub and forest on light soil in SW. Western Australia. Map 6, see p. 180.

Specimens Examined (Selection Only): Western Australia: Irwin District: Geraldton, Lucas NSW 125060, 7.1928 (NSW). Darling District: Swan R, Helmich (MEL); Darling Range, Hotchkiss \& Eames NSW 125070, 9.1953 (NSW); in subarenosis sylvae ad fluvium "Canning River", Preiss 1322, 9.1841 (MEL 1007980, 1007981, 1007982); Dwellingup, Gardner 10.1938 (PERTH); Harvey R, Oldfield (MEL). Warren District: Cape Naturaliste, Wiburd NSW 125059, 9.1904 (NSW); Upper Capel, Sargent 10.1921 (PERTH); Busselton, McHard 10.1884 
(MEL); 4 miles [6 km] S. of Yallingup, Common 0386, 10.1951 (CANB); Kirrup, Koch 2064, 10.1910 (BRI); between Busselton and Nannup, Went 80, 9.1962 (PERTH); 8 miles [13 km] from Nannup towards Northcliffe, Phillips 10.1962 (CBG 010654); Blackwood, Oldfield 202 (MEL); Cape Leeuwin, McHard, 3.1885 (MEL 1008221); Big Brook, Koch 2354, 10.-(BRI); Pemberton, Koch 2646, 11.1921 (MEL); Thompson road, about 24 miles [38 km] N. of Walpole, Belcher 393, 10.1967 (CBG, MEL, NSW, PERTH); c. 8 miles [13 km] S. of Mt Barker, Eichler 15999, 9.1959 (AD); near Mt Many Peaks, Galbraith (MEL); “Monliup", 25 miles [40 km] E. of Albany, Elder NSW 125064, 7.1930 (NSW); Bald Island (MEL 1008007); Albany, Helms 12.1898 (NSW 125055, PERTH); Albany, Mueller 9.1867 (MEL 1007986); in solo turfosoarenoso inter frutices densos ad "Stirlings terrace" (Plantagenet), Preiss 1326, 9.1840 (MEL); King Georges Sound, Brown 1801 (MEL); King Georges Sound, Menzel 29, 9.1895 (AD, NSW); Goadby 115, 9.1901 (PERTH). Stirling District: Tambellup, Pulleine NSW 125058, 11.1918 (NSW); Bremer R, Webb 1884 (MEL 1008002, 1008017, 1008225).

Blackall \& Grieve, Western Austral. Wildflowers 1: 260 (1954), key out a " $T$. setigera var. hispidissima" without author. There is no indication that it is based on $T$. hispidissima Steetz which bears no close similarity to $T$. setigera.

This species has stems which are covered with long setae and it usually has conspicuous antrorse setae on the peduncles. $T$. hirsuta and $T$. hispidissima may also have dense setae on the stems but they can always be readily distinguished by their extremely long tapering tuberculate anther-tubes.

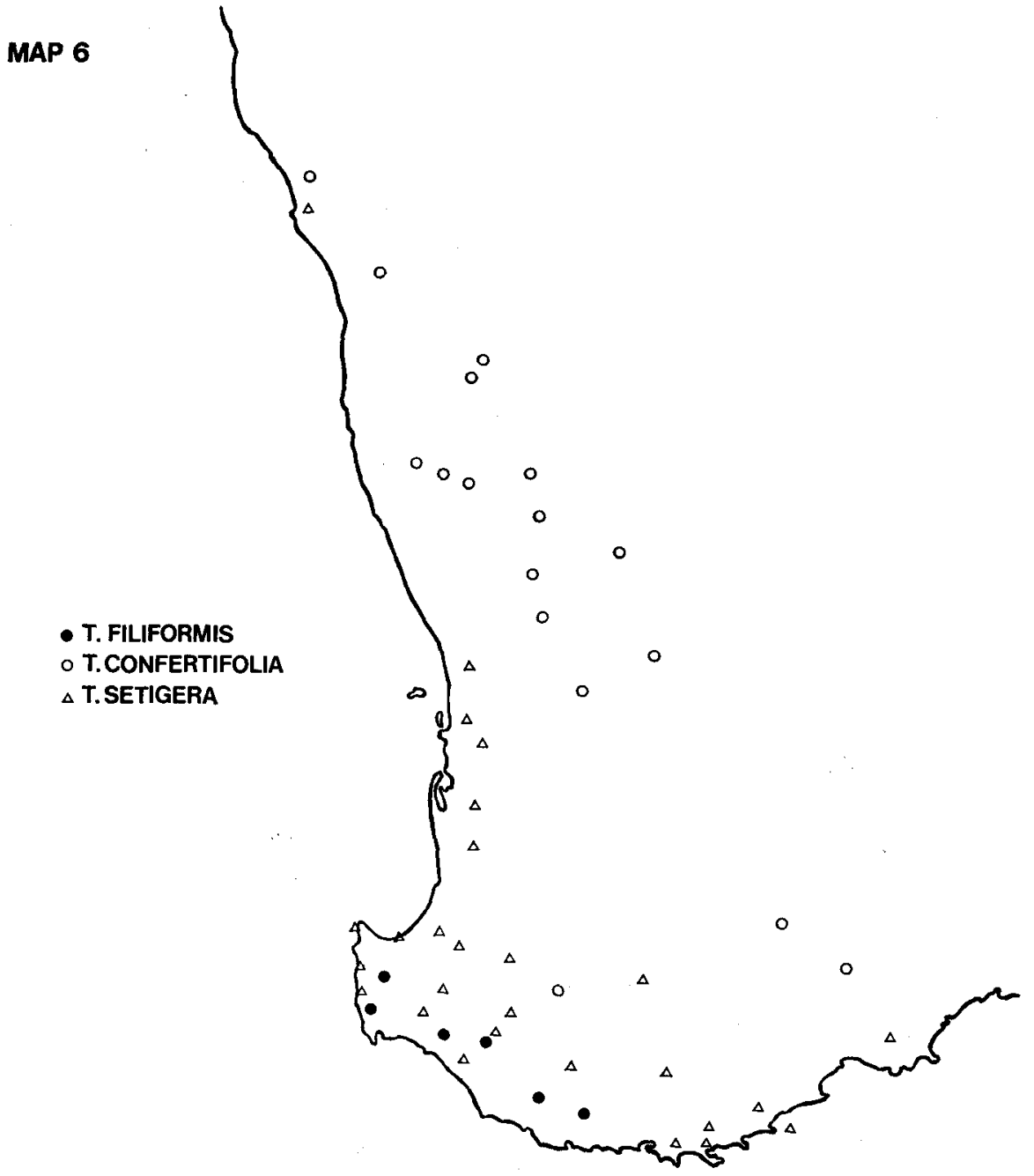


21. Tetratheca confertifolia Steetz in Lehmann, Pl. Preiss. 1: 214 (1845); Walpers, Repert. Bot. Syst. 5: 68 (1845); Steetz, Familie Tremandreen: 10 (1853); Schuchardt, Syn. Tremandr. : 23 (1853); Bentham, Fl. Austral. 1: 133 (1863); F. Mueller, Fragm. 12: 6 (1882); F. Mueller, Syst. Census Austral. PI. 1: 9 (1882); F. Mueller, Second Syst. Census 1: 15 (1889); Diels \& Pritzel in Bot. Jahrb. Syst. 35: 30 (1904); Gardner, Enum. Pl. Austral. Occ.: 71 (1930); Blackall \& Grieve, Western Austral. Wildflowers 1: 260 (1954); Beard, W. Austral. Pl. : 56 (1965).

SYNTYPES: In confragosis montium continuorum "Darlings range" (Perth) in Nova Hollandia occidentali, Preiss 1328, 1.x.1839 (MEL 1007730, annotated by Steetz; MEL 1007729); in regionibus interioribus Novae Hollandiae meridionali-occidentalis, Preiss (? an Drummond ?), Preiss 1329 (MEL 1007731, annotated by Steetz).

A small shrub to $20 \mathrm{~cm}$ in height with numerous, sparsely branched, erect or spreading stems arising from a stout, branched, woody, perhaps rhizomatous stock. Stems terete, covered with white, curved, antrorse hairs, some stouter than others, the hairs dense on the upper branches, the stems $0.5-1.0 \mathrm{~mm}$ broad in the flowering region, the branches alternate but with several arising close together so as to appear whorled. Leaves alternate, very close together on the upper branches, the majority c. $5 \mathrm{~mm}$ in length, linear, obtuse, somewhat incurved at the tip, the margins strongly revolute, the upper surface covered with short and long, stiff, white hairs, occasionally with glandular tips, the lower surface pubescent but scarcely visible, the petiole short but distinct. Flowers occurring singly in the axils of upper leaves and without bracts. Peduncles elongating as the flower matures, $15-40 \mathrm{~mm}$ long, pale or darkcoloured, with dense, curved, antrorse setae of varying lengths up to $0.5 \mathrm{~mm}$, and occasionally spreading, broad-based pale or dark-stemmed, red-tipped glandular hairs to $0.5 \mathrm{~mm}$ in length, the top often curved, broadening to a receptacle little more than $1 \mathrm{~mm}$ in diameter; often swollen at the extreme base. Calyx-segments 5, deciduous, pale or dark, narrowly ovate or deltoid, acute to long-acuminate, 3.5-5 $\mathrm{mm}$ long, with dense or sparse, shining antrorse setae and some scattered glandular hairs, the inner surface covered with long dense fine hairs, the base of each segment unthickened except perhaps on a central ridge but strongly curved back over the edge of the receptacle. Petals 5, dark pink, occasionally white, rarely varying on one plant, usually broadly linguiform, $8-11 \mathrm{~mm}$ long and a little more than $\frac{1}{2}$ as wide with the greatest width above the centre and often very near the apex, deciduous. Stamens usually $10,3.5-4 \mathrm{~mm}$ long; filament very short, $0.25 \mathrm{~mm}$ long, leaning back over the base of the petal and merging into the body of the anther; body of the anther narrowed at the base and strongly curved or angled above this, purple, shining and smooth or hairy especially near the base, $2 \mathrm{~mm}$ long, tapering to the anther-tube; anther-tube rather broad, curved, $1.5 \mathrm{~mm}$ long with an oblique orifice (fig. 4). Ovary densely pubescent and with glandular hairs, sessile, the style $2.5 \mathrm{~mm}$ long. Ovules 2, 1 in each loculus, attached to the upper part of the central axis. Fruit cuneate-oblong to obcordate, to $9 \mathrm{~mm}$ in length, and to $5 \mathrm{~mm}$ in width near the top, pubescent, the seeds leaving no thickening on the placenta. Seeds $4 \mathrm{~mm}$ long, light-brown, cylindrical, rounded at the base, truncate at the apex, with a scar on the adaxial surface and a narrow pale ridge extending to the apex from it, covered with sparse very fine spreading hairs, the appendage cream, loosely coiled towards the axis, with sparse fine hairs.

Distributron: In sclerophyll scrub on light soils on sandplain and gravel, in SW. Western Australia. Map 6, see p. 180.

Specimens Examined (Selection Only): Western Australia: Irwin District: Howathara, Moresby Range, Burns 1036, 8.1966 (PERTH); between the rivers Murchison and Irwin, Sewell (MEL); 27 miles [43 km] SE. of Walkaway, George 7848, 9.1966 (PERTH, NSW); Three Springs, Blackall 4434, 8.1940 (PERTH); 3 N. of Cockleshell road junction and c. 114 N. of Gin Gin, Vasek 681009-63, 10.1968 (CANB). North Avon and Darling Districts: W. of Watheroo, halfway to Badgingarra, Ashby $1928,9.1966$ (AD); 2 miles [3 km] NW. of Badgingarra, Gittins $1716,9.1967$ (BRI, NSW, PERTH); road to Jurien Bay from Moora, Clyne NSW 125049, 9.1969 (NSW); Moora, Ashby 66, 9.1946 (PERTH); Wongan Hills, 5 miles [8 km] NW. of Wongan Hills township, Willis 9.1963 (MEL); Gillingarra, in fruticetis Moore R, Pritzel 727, 10.1901 (AD, NSW, PERTH); E. of New Norcia, Hill 1442, 10.1964 (AD); Bindoon, Gardner 7699, 10.1945 (PERTH); Wooroloo, Koch 1542, 9.1906 (MEL, NSW); in confragosis montium 
continuorum Darlings range, Preiss 1328, 11.1839 (MEL 1007729, 1007730). Stirling District: Towards the Tone R, Muir 1880 (MEL); 3 miles [5 km] N. of Needilup, Newbey 1874, 12.1965 (PERTH). Eyre District: 10 miles [16 km] from Jerramungup towards Raventhorpe, Wrigley $N S W \quad 114881,10.1968$ (NSW). Without precise locality: In regionibus interioribus Novae Hollandiae meridionali-occidentalis, Preiss 1329 (MEL 1007731); Western Australia, Drummond 100 (MEL), Drummond (MEL 1007727, 1007728).

This species can be immediately recognized by its crowded leaves, long peduncles and long narrow calyx-segments. It appears to have some affinity with $T$. filiformis in spite of its different appearance (see note under that species).

22. Tetratheca filiformis Benth., Fl. Austral. 1: 135 (1863); F. Mueller, Fragm. 12: 8 (1882); F. Mueller, Syst. Census Austral. P1. 1: 9 (1882); F. Mueller, Second Syst. Census 1: 15 (1889); Gardner, Enum. Pl. Austral. Occ.: 71 (1930); Blackall \& Grieve, Western Austral. Wildfiowers 1: 260 (1954); Beard, W. Austral. Pl.: 56 (1965).

SYNTYPES: On the Franklin R [Western Australia], Maxwell (MEL 1007789); Swan River, Drummond, Coll. 1843, n. 197 (MEL 1007791 is probably a duplicate); Swan River, Drummond, Coll. 1843, n. 181 (I have not seen this specimen).

A diffuse shrub with slender trailing stems to $40 \mathrm{~cm}$ in length arising from a rather slender, perhaps rhizomatous, woody stock and branching above but near the stock. Stems very slender, terete but swollen below the nodes and somewhat longitudinally ridged, glabrous or more frequently with areas of short, fine, curled, mostly retrorse hairs and often scattered longer straight hairs or a few stout darktipped hairs below the nodes, the stems $0 \cdot 1-0.4 \mathrm{~mm}$ broad in the flowering region, the branching alternate and at an acute angle. Leaves in whorls of 3 or occasionally opposite, ovate to narrowly lanceolate or narrowly elliptical, from less than 5 to almost $20 \mathrm{~mm}$ in length, the apex with a straight point, the margins flat, recurved or revolute at the edges, entire or with an occasional spiny tooth or dentate with the teeth spiny, the upper surface with scattered white hairs, the lower much paler and glabrous or with scattered white hairs, the petioles distinct. Flowers occurring singly in the axils of upper leaves and without bracts. Peduncles elongating as the flower matures, 15 to more than $50 \mathrm{~mm}$ in length, slender, pale, with sparse or numerous short, fine, curled hairs, occasionally some longer or straight near the top but still less than $0.5 \mathrm{~mm}$ in length, or with areas of coloured long glandular-tipped hairs, enlarging somewhat at the top of form a receptacle less than $1 \mathrm{~mm}$ in diameter; often swollen at the extreme base. Calyx-segments 5, deciduous, often rather darkcoloured, 1.5-2 mm long, broadly ovate, acuminate, glabrous or with short, irregularly directed, rather curved hairs, often with occasional broad-based short glandular hairs on or near the margin, the inner surface covered with hairs, each segment attached inside the top of the receptacle and the lower part unthickened and curved back over the edge. Petals 5, dark pink, usually broad-linguiform, 6-8.5 $\mathrm{mm}$ long and $c$. $\frac{2}{3}$ as wide with the greatest width usually in the upper $\frac{1}{2}$, hairy at the base of the inner surface, deciduous. Stamens usually $10,3 \mathrm{~mm}$ long; filament very stout and leaning back over the petal, c. $0.5 \mathrm{~mm}$ long and merging into the body of the anther; body of the anther dark purple, $1.5 \mathrm{~mm}$ long, very curved, shining, smooth, glabrous or with occasional hairs, abruptly contracted into the anther-tube; anthertube curved, narrow, $1.5 \mathrm{~mm}$ long with a very oblique orifice. Ovary glabrous to densely pubescent, with stiff shining hairs, sometimes with short glandular hairs; more or less expanded at the base to form a very short stout stalk to the young fruit, the style slender or broad at the base, 1.5-2 mm long. Ovules 2, 1 in each loculus, attached to the upper part of the central axis. Fruit turgid each side of the central axis, rounded at the top and very cordate at the base, $2 \cdot 5-3 \cdot 3 \mathrm{~mm}$ long and somewhat more in width, pubescent. Seeds c. $2 \mathrm{~mm}$ long, obovoid, with somewhat dense spreading hairs, pale brown, with a scar at the base of the adaxial side, the appendage twisted towards the adaxial side, curled only near the tip but broad with sparse spreading hairs.

Distribution: In sandy forest soil and on creek banks in dry sclerophyll forest in SW. Western Australia. Map 6, see p. 180. 
Specimens Examined: Western Australia: Warren District: Rosa Brook, Royce 4624, 10.1953 (PERTH); McLeods Creek, Karridale, Royce 4634, 10.1953 (PERTH); Karri Daie (MEL); edge of Donnelly R, Davies 429, 1.1964 (PERTH); Big Brook, Koch 2596 K,12. 1921 (PERTH); Pemberton, Koch 2596, 11.1921 (NSW); Shannon R, Gardner 1.1936 (PERTH); on the Franklin R, Maxwell (MEL 1007789); Bow R, Jackson NSW 125089, 11.1912 (NSW); Bow R, Jackson NSW 125090, 12.1912 (NSW). Without precise locality: Western Australia, Drummond 197 (MEL 1007791).

This species with its lax habit and extremely slender stems is very distinct. Its closest affinities appear to be with $T$. confertifolia. In these two species the peduncle is very long and somewhat swollen at the base, also the calyx-segments are unthickened at the base and curved back over the edge of a small receptacle.

23. Tetratheca juncea Sm., Specimen Bot. New Holland: 5, t. 2 (1793); Willdenow, Sp. P1. 2: 321 (1799); Persoon, Syn. Pl. 1: 419 (1805); Aiton, Hort. Kew. [ed. 2] 2: 347 (1811); J. E. Smith in Rees Cycl. 35 (2): (1817); Steudel, Nomencl. Bot.: 828 (1821); Candolle, Prodr. 1: 343 (1824); Sprengel, Syst. Veg. 2: 214 (1825); Steudel, Nomencl. Bot. [ed. 2] 2: 673 (1841); Walpers, Repert. Bot. Syst. 5: 70 (1845); A. Gray in Hooker's J. Bot. Kew Gard. Misc. 4: 200 (1852); Steetz, Familie Tremandreen: 11 (1853); Schuchardt, Syn. Tremandr.: 18 (1853); Bentham, Fl. Austral. 1: 132 (1863); Woolls, Pl. Indig. Neighb. Sydney: 11 (1880); F. Mueller, Fragm. 12: 6 (1882); F. Mueller, Syst. Census Austral. P1. 1: 9 (1882); C. Moore, Census Pl. New South Wales: 5 (1884); F. Mueller, Second Syst. Census 1: 15 (1889); Moore \& Betche, Handb. Fl. New South Wales: 36 (1893); Cheel in Proc. Linn. Soc. New South Wales 38: 528 (1913); Maiden \& Betche, Census New South Wales Pl.: 119 (1916); Beadle, Evans \& Carolin, Handb. Vasc. Pl. Sydney Distr.: 147 (1963); Beadle, Evans \& Carolin, Fl. Sydney Region: 172 (1972); Beadle, Stud. Fl. NE. New South Wales: 157 (1973).

TyPE: I have not attempted to see Smith's specimens. There is no confusion about this species and the description and figure in Specimen of the Botany of New Holland are clear and detailed.

A prostrate, usually leafless, shrub with stems to $1 \mathrm{~m}$ in length, branching above a woody stock, the stock often horizontal and rhizomatous. Stems with 2 or 3 wings or somewhat quadrangular at the base, $0.8-1.5 \mathrm{~mm}$ broad in the flowering region, glabrous and covered with minute tubercules, the branches erect, alternate. Leaves alternate, to $20 \mathrm{~mm}$ in length and $5 \mathrm{~mm}$ in width, usually narrow-elliptical but at the base occasionally obovate, both surfaces glabrous, the lower somewhat paler, the margins flat or recurved, the apex blunt or pointed, the petiole absent; usually all leaves reduced to glabrous, very narrowly deltoid scales $3 \mathrm{~mm}$ or less in length. Flowers occurring singly or 2 together in leaf-axils, the bracts minute to $1 \mathrm{~mm}$ in length, light brown, linear-lanceolate, concave and glabrous or with a few hairs. Peduncles 5-10 mm long, tending to twist in the lower part, glabrous, dark towards the top, the top gradually expanding to a receptacle less than $1 \mathrm{~mm}$ in diameter. Calyx-segments 4, deciduous, 1-1.5 mm long, usually dark-coloured and shining, usually almost orbicular, often broader than long, obtuse to somewhat acuminate but the upper margins often almost crenulate, glabrous except on the inner surface which has fine hairs near the margin towards the apex, each segment attached at the edge of the receptacle and the base curved over the receptacle and top of the peduncle. Petals 4, dark pink, rarely white, obovate to broadly linguiform, $7-11 \mathrm{~mm}$ long and usually $\frac{2}{3}$ or more as wide with the greatest width in the upper $\frac{1}{3}$, deciduous. Stamens $8,3-3.5 \mathrm{~mm}$ long; filament $0.5 \mathrm{~mm}$ or less in length; body of the anther $2-2.5 \mathrm{~mm}$ long, glabrous, the base flattened for the lower $0.5 \mathrm{~mm}$ and then abruptly curved or angled to approximately $90^{\circ}$, the apex tapering to the anthertube; anther-tube tapering, somewhat curved, c. $0.75 \mathrm{~mm}$ long with a rather narrow orifice. Ovary glabrous, on a very conspicuous broad base, the top tending to taper to a glabrous, slender style 1.75-2 mm long. Ovules 4,2 in each loculus, attached in pairs near the centre of the axis. Fruit obovate, often beaked, somewhat 
stalked, $6-8 \mathrm{~mm}$ long and $\frac{1}{2}-\frac{2}{3}$ as wide, the seed leaving a scar on the axis. Seeds c. $4 \mathrm{~mm}$ long, obovoid-cylindrical with a scar near the base, oblique at the base and flat on the adaxial surface, with fine brown appressed hairs, the appendage cream, irregularly twisted beyond the seed, hairy.

Distribution: In sandy, occasionally somewhat swampy, heath and dry sclerophyll forest in coastal New South Wales. Map 7, see below.

Specimens Examined (Selection Only): New South Wales: North Coast: Alum Mt, Bulladelah, Rupp 2.1924 (MEL); above quarry, Mt Bulladelah, Ford NSW 125305, 10.1951 (NSW); Pacific Highway, 2 miles [3 km] N. of Karuah, Telford 8.1967 (CBG 022178); Wallaroo, Burgess NSW 125292, 8.1961 (NSW); Wallsend, Boorman NSW 19693, 9.1904 (NSW, BRI), Boorman NSW 125308, 10.1899 (NSW); near Wallsend, Williams 10.1961 (CBG 002921, 003006); Newcastle, Cambage 433, 7.1901 (NSW); New Lambton, Newcastle, Wilson NSW 125297, 9.1937 (NSW); Wakefield via Killingworth, Sullivan NSW 125289, 10.1940 (NSW); Toronto, Lucas NSW 125286, 10.1926 (NSW); Jewells Swamp, Belmont, Baxter NSW 114382, 9.1970 (NSW); Belmont, Baxter NSW 114380, 12.1970 (NSW); Central Coast: Lake Macquarie (NSW 125295, 125300); near Lake Macquarie, Lamont 285 (MEL); Morisset, Boorman NSW $125291,9.1907$ (NSW); Morisset, Evans 9.1925 (CANB 5623); Pacific Highway, 4 miles [6 km] S. of Swansea, Coveny 2130, 9.1969 (NSW); between Wyee and Cooranbong, Burgess 9.1963 (CBG 002920); Wyee, Burgess 8.1963 (CBG 006533); Ballman, Leichhardt NSW 125301, 7.(NSW); Five Dock, Deane NSW 125299, 10.1884 (NSW); Undercliffe, Fletcher NSW 125296, 9.1889 (NSW); Bexley, Williams NSW 125307, 8.1913 (NSW); Kogarah, Camfield NSW 125306,

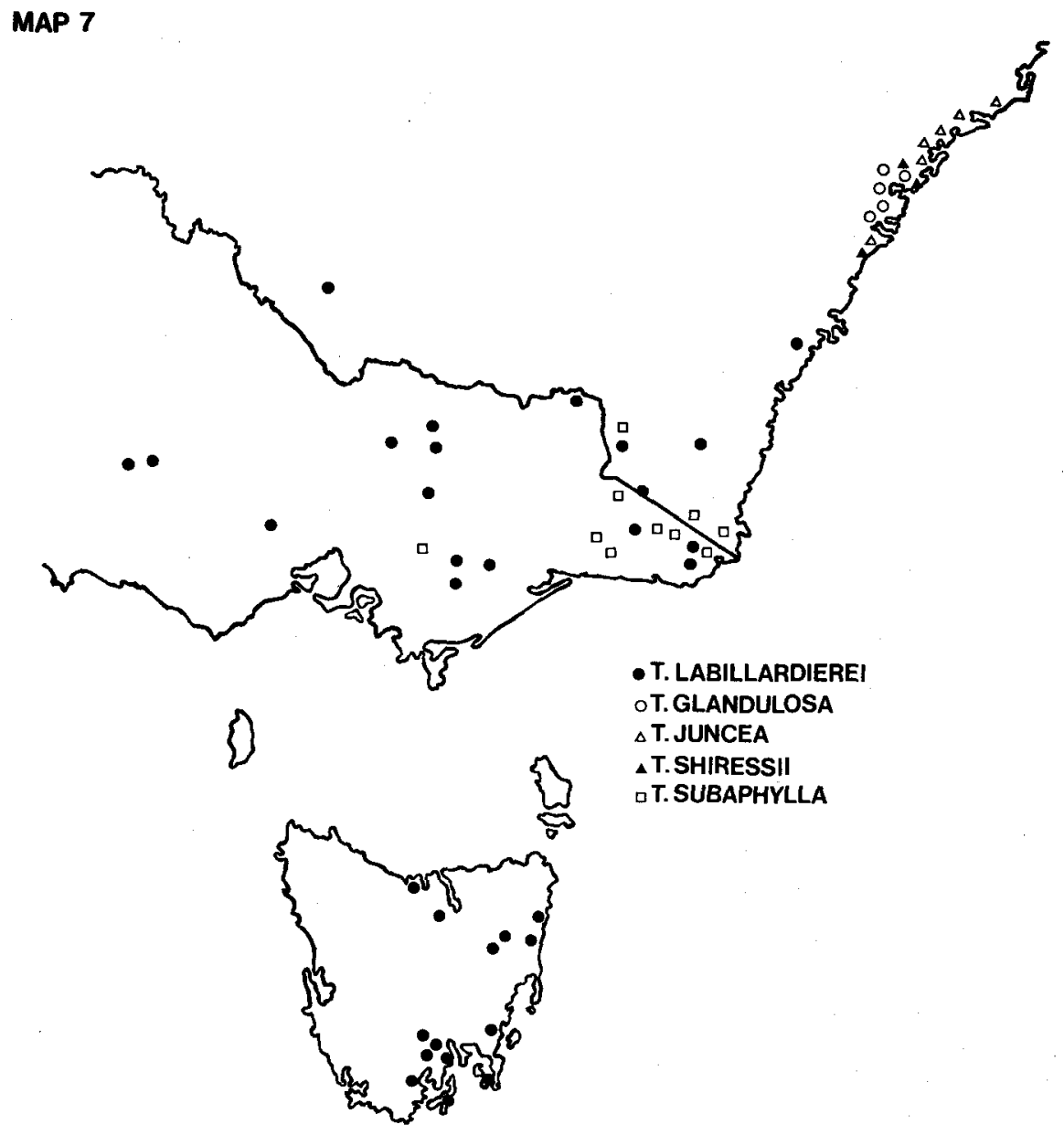


9.1893 (NSW); Carlton, Camfield NSW 125302, 125290, 8.1893 (NSW); Port Jackson, Brown (BRI, MEL 1007879, NSW 125293, 125294); Port Jackson, Brown 1802-5 (MEL 1008419, 1008420, NSW 125304); Sydney, Mossman 208 (BRI). Without precise locality: New South Wales, Suttor (BRI); New South Wales, Cunningham (MEL); Nova Hollandia orientali, Sieber, Fl. Nov. Holl. 235, Fl. mixta 529 (MEL 1007877, 1007878, 1008378); Australia, Schomburgk (AD).

The winged stem distinguishes $T$. juncea from other Eastern Australian species. T. affinis, the other winged species, differs in the calyx and receptacle. The affinities of this species are obscure but it bears some resemblance to T. subaphylla.

24. Tetratheca shiressii Blakely in Proc. Linn. Soc. New South Wales 50: 384 (1925); Beadle, Evans \& Carolin, Handb. Vasc. Pl. Sydney Distr.: 147, 148 (1963); Beadle, Evans \& Carolin, Fl. Sydney Region: 171, 172 (1972).

Holotype: Kariong Trig., head of Mullet Creek, Wondabyne district, New South Wales, W. F. Blakely \& D.W. C. Shiress 9.1923 (NSW 125153), cited as 'Kariong Trig. three miles northwest of Wondabyne. . .', without date.

A sprawling, weak-stemmed shrub usually $30-75 \mathrm{~cm}$ in height with numerous wiry stems arising from one or several places on a woody stock which may be either above or below the ground. Stems terete, somewhat vertically ridged, of two kinds, one glabrous, one with dense tubercle-based, pale brown, antrorse setae to $1 \mathrm{~mm}$ in length, the stems $0.3-1.5 \mathrm{~mm}$ broad in the flowering region, the branches opposite, alternate or several together and at an acute angle. Leaves of the glabrous branches opposite or in whorls of 3 , rarely 4 , usually $10-20 \mathrm{~mm}$ in length and $1 \mathrm{~mm}$ or less in width, linear, glabrous or with a few fine hairs especially towards the base of the upper surface, the margins closely revolute, the apex slightly incurved, tapering to a firm blunt or almost pungent point, the petiole short or absent. Leaves of the pubescent branches usually in whorls of 3 or 4, rarely 5, occasionally opposite, 4-12 $\mathrm{mm}$ long and up to $6 \mathrm{~mm}$ wide, broad-elliptical to ovate or even almost orbicular, the upper surface glabrous or with coarse stout-based hairs or their bases especially near the margin, the lower surface much paler, glabrous except for a few setae on the broad lower midrib, the margins flat, undulate or somewhat revolute, the apex usually tapering to a blunt point, the petiole short or absent. Flowers occurring in the axils of upper leaves of both types, the bracts $1-2 \mathrm{~mm}$ long, light brown, linear to lanceolate or oblanceolate, concave and glabrous or with some fine hairs especially on the upper surface. Peduncles dark-coloured, 5-12 mm long, glabrous or with occasional setae, expanding conspicuously and somewhat angled in the upper part, expanding again, usually abruptly, at the top to form a receptacle c. $1.5 \mathrm{~mm}$ in diameter. Calyxsegments 4, deciduous, usually dark-coloured, 3-6 $\mathrm{mm}$ long, broad-lanceolate to ovate, acute to acuminate, glabrous except on the inner surface which has a few hairs in the upper part near the margin, the base of each segment set well inside the top of the receptacle, the lower part of the segment with a somewhat thickened ridge across it above the outer rim of the receptacle. Petals 4, dark pink, rarely pale pink, obovate to linguiform, 10-20 mm long and usually a little less than $\frac{1}{2}$ as wide with the greatest width above the centre, usually in the upper $\frac{1}{3}$, deciduous. Stamens $8,3.5-4.25 \mathrm{~mm}$ long, the filament $0.7-1 \mathrm{~mm}$ long, the body of the anther, c. $2.5 \mathrm{~mm}$ long, glabrous or rarely with a few minute hairs, curved at the base and fiattened for c. $0.5 \mathrm{~mm}$ above the filament, scarcely contracting at the apex to the anther-tube; anther-tube broad, $0 \cdot 8-1 \mathrm{~mm}$ long, tapering to a variable extent to an often rather broad orifice. Ovary covered with very minute dense stiff hairs and scattered small glandular-tipped hairs; the base broad, the apex tapering to a style 2-3 mm long with very minute hairs at the base and often some glandular hairs. Ovules 4, 2 in each loculus, attached close together in pairs just above the centre of the axis. Fruit obovate, somewhat stalked, $7.5 \mathrm{~mm}$ long and $\frac{2}{3}$ as broad, but not seen in mature condition. Seeds not seen.

DISTRIBUTION: In rocky, sandy or occasionally somewhat swampy heath in central coastal New South Wales. Map 7, see p. 184. 
Specimens Examined (Selection Only): New South Wales: Central Coast: Walker's Ridge Road, Wattagan State Forest, Dony NSW 115891, 9.1973 (NSW); Mangrove Mtn, Shiress \& Blakely NSW 125159, 7.1926 (NSW); Mangrove Mtn, Burgess 10.1958 (CBG 002925); Somersby, Chippendale NSW 125157, 125161, 8.1953 (NSW); Gosford, Fletcher NSW 125166, 9.1888 (NSW); Calga, Burgess 8.1961 (CBG 006815); the Lookout, Woy Woy, McBarron 17574, 8.1969 (NSW); Bulls Hill, SW. of Woy Woy, McBarron 17658, 8.1969 (NSW); Mt White, Burgess 8.1962 (CBG 002926); between Wondabyne and Woy Woy, Blakely NSW 125179, 8.1936 (NSW); Kariong Trig., head of Mullett Creek, Blakely \& Shiress NSW 125153, 9.1923 (NSW); Wondabyne, Shiress \& Blakely NSW 125180, 9.1923 (NSW); head of Patonga Creek, Blakely, Shiress \& Bott NSW 125162, 10.1923 (NSW); Patonga Beach, Galbraith 9.1967 (MEL); Piles Creek, Hawkesbury R, Blakely \& Shiress NSW 125178, 10.1926 (NSW); Peats ferry, Constable NSW 19177, 7.1951 (NSW); Kangaroo Point, Hawkesbury R, Fraser NSW 114397, 7.1931 (NSW); Peats Ridge, Chippendale NSW 125163, 8.1951 (NSW); Cronulla, Rodway NSW 125164, 8.1933 (NSW); Port Hacking, Cheel NSW 3737, 8.1915 (NSW, AD); National Park, Day 9.1936 (CANB 10323); National Park, near road from Audley to Wattamolla, Goode 421, 10.1961 (NSW); Uloola track, Royal National Park near Waterfall, Coveny 2110, 9.1969 (NSW); Waterfall, Deane NSW 125172, 9.1888 (NSW); Helensburgh, Baker NSW 125170, 9.1895 (NSW); Bulli Pass-Appin Road, 5 miles [ 8km] from Bulli Pass, Rodway NSW 125165, 9.1934 (NSW).

I have not seen Foster's specimens cited by Blakely nor the specimens bearing fruits and seeds which he describes.

$T$. shiressii is readily distinguished from all other species by its dimorphic character. The affinities of this species are obscure as neither the flowers nor either of its vegetative forms bears a close similarity to any other species.

25. Tetratheca subaphylla Benth., Fl. Austral. 1: 132 (1863); Ewart et al., Field Nat. Club Census Pl. Victoria: 40 (1923); Ewart, Fl. Victoria: 713 (1931); J. H. Willis, Handb. Pl. Victoria 2: 196 (1973).

SynTYPES: Granite Rocks at the White Rock Hill, 3000' $9910 \mathrm{~m}$ ], [New South Wales], Ferd. Mueller 9.1860 (MEL 1008030); Sources of the Genoa River [New South Wales] (MEL 1008034); Sources of the Genoa River [New South Wales], $F$. $v$. Mueller 1860 (NSW 125113). I am sure each of these specimens is part of the one original collection.

Synonymy: Tetratheca ericifolia var. aphylla F. Muell., Pl. Indig. Colony Victoria 1: 183 (1860-1862). SynTYPES: As for T. subaphylla Benth.

A straggling or semi-prostrate shrub with stems, as seen in specimens, $60 \mathrm{~cm}$ in length, the woody stock rather slender. Stems terete, often ending in a blunt point, glabrous or rarely with occasional fine long white hairs, covered with minute tubercles rarely, above the nodes, elongating into minute, white, antrorse or retrorse hairs, the stems $0.6-1.3 \mathrm{~mm}$ broad in the flowering region; the branching alternate and usually at an acute angle but the branches often recurving. Leaves alternate, $15 \mathrm{~mm}$ long, broadly oblanceolate, flat with recurved margins; rarely seen, usually reduced to narrowly ovate to lanceolate, acuminate, sessile, scales c. $2.5 \mathrm{~mm}$ long, glabrous or with minute tubercles or hairs, and soon deciduous. Flowers occurring singly or 2 together in leaf-axils of the upper branches, the bracts minute to $1 \mathrm{~mm}$ in length, usually brown, linear to lanceolate, obtuse to acute, concave and with some white hairs especially on the upper margins. Peduncles $2-7 \mathrm{~mm}$ long, glabrous with scattered minute shining spots, the top of the peduncle gradually broadening and often angled, expanding into a receptacle $1 \mathrm{~mm}$ or less in diameter. Calyx-segments 4 , deciduous, usually dark-coloured and shining, glabrous on the outer surface with some shining spots, the inner surface with fine hairs near the margin which usually show from the outside near the apex, c. $1 \mathrm{~mm}$ long, broadly ovate to orbicular, obtuse to somewhat acuminate, the base of each segment recurved over the receptacle. Petals 4, dark pink, or pale pink, perhaps occasionally white, obovate, $7 \cdot 5-10 \mathrm{~mm}$ long and $\frac{1}{2}$ as wide or less with the greatest width in the upper $\frac{1}{2}$, deciduous. Stamens $8,2 \cdot 5-3 \mathrm{~mm}$ long; filament less than $0.5 \mathrm{~mm}$ in length; body of the anther c. $1.5 \mathrm{~mm}$ long, glabrous, the base flattened for $0.2-0.4 \mathrm{~mm}$ above the filament and then curving abruptly almost at a right angle, the apex tapering somewhat to the anther-tube; anther-tube broad, $0.7 \mathrm{~mm}$ long, variably tapering to a broad orifice. Ovary densely or rather sparsely covered with minute stiff hairs and with scattered small glandulartipped hairs; the base broad, the apex straight to somewhat emarginate with the 
slender style $2 \cdot 5-3.5 \mathrm{~mm}$ long and narrow at the base with minute, stiff hairs. Ovules 2,1 in each loculus, attached at the top of a thickened central axis. Fruit obovate to obcordate, slightly stalked, 3-4 mm long and $\frac{1}{2}-\frac{2}{3}$ as broad. Seeds $2 \cdot 5-3 \mathrm{~mm}$ long, somewhat obovoid but with the adaxial side rather concave, truncate at the apex, light chestnut brown with very fine spreading hairs, the appendage cream, with fine spreading hairs, the upper part white, extended along the side of the seed or irregularly wound around itself.

Distribution: On rocky hillsides usually in mountain eucalypt forest on the far South Coast and Tablelands of New South Wales and in E. Victoria. Map 7, see p. 184.

Specimens Examined: New South Wales: South Coast: Upper slopes of Mt Imlay, Rodway NSW 125115, 3.1937 (NSW). Southern Tablelands: Geehi R Valley, Woodhams NSW 125112, 12.1957 (NSW); Geehi Woodhams 10.1958 (CBG 002993); Claymore Creek aqueduct, Snowy Mtns, Raine ANU 10314, 12.1971 (NSW); Sources of the Genoa R (MEL 1008034); Sources of the Genoa R, Mueller NSW 125113, 1860 (NSW); White Peak Hill, Mueller 9.1860 (MEL 1008030).

VICTORIA: Eastern Highlands: N. and Bowen Range, Beauglehole 37198, 3.1971 (NSW); Granite area of Mt Kay and Back Creek, Upper Cann R valley, Wakefield 10.1946 (MEL); Genoa, 1883 (MEL); Combiebar road, Beauglehole 34194, 9.1970 (NSW); Mouth of W. Tree Creek, Murrindal, Wakefield 10.1947 (MEL); W Tree Creek, Murrindal, 13 miles [22.5 km] N. of Buchan, Constable 5370, 10.1964 (NSW); near Mt Buck, E. Gippsland, French 1.1890 (MEL); Upper Yarra Ranges, Mueller 1.1863 (MEL); Ranges on the Upper Yarra (NSW 125116); Upper Yarra, Staer NSW 125114, 4.1911 (NSW).

Its terete leafless stems serve to distinguish $T$. subaphylla from all other Eastern Australian species and its small calyx-segments to distinguish if from all Western Australian species. This small calyx and a similar receptacle seem to link this species to $T$. juncea but these species differ in the number of ovules.

26. Tetratheca glandulosa Sm., Exot. Bot. 1: 39, t. 21 (Mar. 1805); Rudge in Trans. Linn. Soc. London 8: 294 (1807); J. E. Smith in Rees Cycl. 35 (2): (1817); Steudel, Nomencl. Bot.: 828 (1821).

TYPE: I have not seen Smith's specimen, probably collected by White at Port Jackson, New South Wales, but from his illustration, which is unfortunately very stylized, and his good description there can be no doubt of its identity.

Synonymy: Tetratheca denticulata Sieber. ex Spreng., Syst. Veg. 4: 147 (1827); W. J. Hooker in J. Bot. (Hooker) 1: 249 (1834-1836) referring to Herb. No\%. Holl n. 236; Steudel, Nomencl. Bot. [ed. 2] 2: 673 (1841); Schuchardt, Syn. Tremandr.: 28 (1853). Holotype: Nov. Holl. Sieber [236] (not seen). IsoTYPES: In Nova Hollandia, Sieber, Flor. Nov. Holl. No. 236, herb. Sonder (MEL 1008360); Sieber, Flora nov. Hollandiae, 236, herb. Laing (MEL 1007735).

Tetratheca pilosa var. denticulata Sieber ex Steetz, Familie Tremandreen: 11 (1853) nomen nudum.

Tetratheca pilosa var. denticulata (Sieber ex Spreng.) Benth., Fl. Austral. 1: 132 (1863); Cheel in Proc. Linn. Soc. New South Wales 38: 528 (1913); Beadle, Evans \& Carolin, Handb. Vasc. Pl. Sydney Distr.: 147 (1963); Beadle, Evans \& Carolin, Fl. Sydney Region: 171 (1972). TYPE: As for Tetratheca denticulata.

A low-growing spreading shrub, occasionally $50 \mathrm{~cm}$ but often $20 \mathrm{~cm}$ or less in height, usually branching several times above but close to a woody stock. Stems slender, terete, somewhat vertically ridged below the nodes on younger growth, often covered with irregular vertical ridges with the thick bases of stout hairs spread along them, most parts usually covered with fine, white, curved, mostly retrorse hairs and with small tubercles and scattered brown short stout hairs to $0.5 \mathrm{~mm}$ in length with very thick bases, and very rarely an occasional small glandular tip, especially just below each leaf, the stems $0.5-0.8 \mathrm{~mm}$ broad in the flowering region, the branching alternate or opposite with the branches often spreading widely from the main stem. Leaves alternate to opposite or, more rarely, in whorls of 3 or even 4, (3-) 5-10 (-20) $\mathrm{mm}$, long and c. $1(-2) \mathrm{mm}$ wide, usually appearing linear owing to the rolled margin but often tapering towards the base, the upper surface with scattered, short, stiff, white hairs or glabrous but almost always with short, stoutbased, stiff, occasionally glandular-tipped, setae towards the margin giving the leaf a 
denticulate appearance, the lower surface usually glabrous but scarcely seen, the broad midrib often with stout glandular hairs or their persistent bases, the apex somewhat curved upward with a small point, the margins usually closely revolute, the petiole negligible or absent. Flowers occurring singly or rarely 2 together in the axils of upper leaves, the very variable bracts minute to more than $1 \mathrm{~mm}$ in length, oblong to lanceolate, with a few or dense white hairs and usually a few short stout red glandular hairs and often with a terminal point. Peduncles 3-7 (-10) mm long, often dark-coloured, densely or sparsely covered with fine, white, straight, curved or curled hairs, rarely with these hairs absent, and with numerous dark-red glandulartipped and tubercle-based hairs to $0.5 \mathrm{~cm}$ in length, the top of the peduncle gradually, rarely abruptly, expanding into a receptacle and lacking any articulation at the base of the calyx-segments, usually $1-1.5 \mathrm{~mm}$ in diameter at the base of the segments. Calyx-segments 4, persistent around the fruit, usually dark-coloured, 2-3 mm long, ovate to broadly ovate or ovate-elliptical, acute or obtuse, each edged with glandulartipped hairs or their persistent bases and with glandular-tipped hairs on the back and rarely with a few fine white hairs, the inner surface with fine white hairs especially near the margin. Petals 4, dark pink, occasionally pale pink or white, obovate or narrowly obovate to linguiform or almost broadly cuneate, $4.5-10.5 \mathrm{~mm}$ long and usually $\frac{1}{2}$, or a little more or less than $\frac{1}{2}$, as wide with the greatest width above the centre but varying in position, the petals persisting around the fruit. Stamens usually $8,3-3.5 \mathrm{~mm}$ long; filament broad, occasionally tending to be joined at the base with the other filament in front of the same petal, c. $0.5 \mathrm{~mm}$ long but difficult to distinguish from the base of the body of the anther; body of the anther c. $2 \mathrm{~mm}$ long, glabrous or with stiff hairs, the base very much flattened for $\mathrm{c} .1 \mathrm{~mm}$ and then variously curved often out and then up, often sharply, the apex contracted into the anther-tube; anther-tube $0.75-1.25 \mathrm{~mm}$ long, curved and tapering to a narrow orifice (fig. 4). Ovary with rather dense spreading, slender, glandular hairs usually $0 \cdot 2-0.5$ $\mathrm{mm}$ long, often with a few short shining white hairs among them, rarely glabrous, the apex rounded, the slender style $2 \cdot 5-3 \mathrm{~mm}$ long, glabrous or with straight shining hairs at the base or slender glandular hairs, rarely splitting into 2 . Ovules 2,1 in each loculus, attached to a broad part of the septum. Fruit hidden by persistent flower parts, obcuneate, 3-7 mm long and usually a little more than $\frac{1}{2}$ as broad with the seeds leaving big placentas on the central axis. Seeds more than $3 \mathrm{~mm}$ long, cylindrical, tapered to the base, truncate at the apex, brown, with very fine hairs which are spreading or appressed or somewhat retrorse, the appendage beyond the seed dark cream, with 3-5 coils.

Distribution: In sandy or rocky heath or scrub in the northern part of the Central Coast of New South Wales. Map 7, see p. 184.

Specimens Examined (Selection Only): New South Wales: Central Coast: c. 2 miles [3 km] S. of Sampsons Pass on Old North Road, Briggs NSW 125253, 10.1965 (NSW); Mangrove Mountain, Williams, 9.1965 (CBG 013251); 3 miles [4 km] NE. of Wisemans Ferry on road to Ten Mile Hollow, Briggs NSW 125282, 8.1965 (NSW); Calga, Cross NSW 125265, 8.1945 (NSW); North Maroota, Williams 10.1961 (CBG 002922); Maroota, Burgess 10.1961 (CBG 006807); Glenorie, Blakely NSW 125258, 9.1938 (NSW); Peats road, Deane NSW 125269, 8.1883 (NSW); Cowan, Boorman \& Anderson NSW 125284, 8.1921 (NSW, BRI); between Arcadia and Berowra Ferry, Blakely NSW 125249, 12.1938 (NSW); Kuringai, White 10.1927 (BRI); N. end of Eurabba Road, Duffys Forest, Coveny 599, 10.1968 (NSW); Tunks Creek, Galston Gorge, Johnson 795, 10.1946 (NSW) ; Hornsby, Blakely NSW 125248, 10.1914 (NSW, AD); Waitara, Fitzgerald NSW 125245, 11.1908 (NSW); Tumble-Down-Dick, Blakely NSW 125280, 9.1937 (NSW); Wahroonga, Salasoo 734, 8.1951 (NSW); Frenchs Forest, Clarke 9.1920 (CANB 5607); Oxford Falls, Chippendale NSW 125276, 8.1953 (NSW); between Killara and St Ives, Blakely \& Anderson NSW 3738, 9.1936 (NSW); Pymble, 9 miles $[15 \mathrm{~km}] \mathrm{NW}$. of Sydney, Morrison 10.1896 (MEL); Pennant Hills, Fraser NSW 125264, 11.1927 (NSW); Beecroft, Laseron NSW 125265, 9.1906 (NSW); Lindfield, Cambage NSW 125256, 8.1908 (NSW); Middle Harbour, Helms NSW 125273, 9.1901 (NSW); between Wakehurst Parkway and Manly Reservoir, Coveny NSW 125278, 7.1966 (NSW); Brookvale, Harris NSW 3739, 9.1922 (NSW); Manly, Fletcher NSW 125275, 8.1887 (NSW); Middle Harbour, Spit, Camfield NSW 125261, 8.1897 (NSW); Port Jackson, Brown 1802-1805 (BRI 013020 part., NSW); Ballman, Leichhardt NSW 125247, 7.18-(NSW); Blue Mountains, Atkinson (MEL 1007738); Parramatta, Woolls (MEL 1007734, 1007914, 1007915); Iter Austral., Brown 1802-1805 (MEL 1008423, NSW 125279); in Nova Hollandia, Sieber, Fl. Nov. Holl. 236 (MEL 1007735, 1008360). 
This species was included in Tetratheca pilosa Labill. by Candolle, Prodr. 1: 343 (1824); Sprengel, Syst. Veg. 2: 214 (1825); Steudel, Nomencl. Bot. [ed. 2] 2: 673 (1841); Woolls, Pl. Ind. Neighb. Sydney: 11 (1880) and C. Moore, Census Pl. New South Wales: 5 (1884). W. J. Hooker in J. Bot. (Hooker) 1: 248 (18341836) thought it better placed with ' $T$. glandulosa Labill.' [T. labillardierei].

T. glandulos $a$ is characterized by its persistent calyx-segments, the fruit remaining surrounded by the remains of the flower. This condition is also found in the obviously related $T$. labillardierei and to some extent in the Western Australian $T$. paucifolia. The latter species has somewhat similar stamens but I would hesitate to suggest that it bears a close relationship.

\section{Tetratheca labillardierei $J$. Thompson nom. nov.}

Tetratheca glandulosa Labill., Nov. Holl. Pl. Spec. 1: 96, t. 123 (Nov. 1805) non Smith (Mar. 1805); Candolle, Prodr. 1: 343 (1824); Sprengel, Syst. Veg. 2: 214 (1825); W. J. Hooker in J. Bot. (Hooker) 1: 248 (1834-1836); J. D. Hooker in J. Bot. (Hooker) 2: 408 (1840) including T. pilosa; Steudel, Nomencl. Bot. [ed. 2] 2: 673 (1841); Steetz, Familie Tremandreen: 11 (1853); Schuchardt, Syn. Tremandr.: 33 (1853); J. D. Hooker, Fl. Tasmaniae 1: 34 (1855); Bentham, Fl. Austral. 1: 131 (1863); Spicer, Handb. Pl. Tasmania: 103 (1878); Rodway, Fl. Tasmania: 10 (1903) including ' $T$. ericifolia Sm (partly)' as a synonym; Ewart in Victorian Naturalist 53: 61 (1936); Costin, Ecosyst. Monaro Region New South Wales: 117 (1954); Curtis, Stud. Fl. Tasmania: 57 (1956); J. H. Willis, Handb. P1. Victoria 2: 196 (1973).

TYPE: In capite Van-Diemen, Labillardière. I have not seen Labillardière's specimen but from the description and illustration there can be no doubt of its identity.

Synonymy: Tetratheca glandulosa var. angustifolia Schuchardt, Syn. Tremandr.: 34 (1853). HoLOTYPE: I have not seen any specimen likely to be the Type of this variety.

Tetratheca glandulosa var. orbifolia Blakely ex Court in Victorian Naturalist 63: 175 (1957). HoLoTYPE: Grampians [Victoria], C. Walter 10.1888 (MEL 1007829).

An erect compact shrub to $1 \mathrm{~m}$ in height but often much less, the lateral branches usually numerous and erect, the stock rarely collected but apparently branched and in the Mt Budawang, N.S.W., specimen interlocked and appearing rhizomatous. Stems terete but often covered with vertical ridges extending from stout hair-bases, covered with fine, white, curved, usually retrorse hairs with small swollen bases interspersed with scattered or dense, stout, white or pale setae from 0.5 to more than $1 \mathrm{~mm}$ in length, the tips usually glandular, very dark and often large (fig. 1), the stems $0.5-1.6 \mathrm{~mm}$ broad in the flowering region, the branching alternate, and at an acute angle. Leaves alternate or rarely some irregularly opposite, $(2-) 3-10(-20) \mathrm{mm}$ long and rarely wider than $5 \mathrm{~mm}$, very variable in shape, usually oblanceolate to broadly obovate but often widest below the centre, occasionally almost orbicular and sometimes appearing linear owing to the rolled margins, the upper surface covered with fine white hairs and/or short rather stiff hairs, rarely almost glabrous, and with some glandular hairs similar to those on the stems near the margins, the apex often incurved and bearing a glandular hair with a broad base or just its base, the petiole distinct, $(0.5-) 1(-2) \mathrm{mm}$ long with dense fine hairs and a few glandular hairs. Flowers occurring singly or 2 together in the axils of upper leaves (one specimen has one branched 2-flowered inflorescence and at least one a bract near the centre of the peduncle), the bracts $1-2.5 \mathrm{~mm}$ long, lanceolate, often concave, with numerous white, straight hairs and a few short, large-headed, glandular hairs. Peduncles 3-7 mm long, densely covered with numerous white to pale-brown tubercle-based and large-, usually red-, glandular-headed hairs $0.5-2 \mathrm{~mm}$ long, the top of the peduncle gradually expanding to a receptacle $1-1.5 \mathrm{~mm}$ in diameter, and lacking any, articulation at the base of the calyx-segments. Calyx-segments 4, tardily deciduous or persistent around the fruit, $1.5-3 \mathrm{~mm}$ long, broad-lanceolate to orbicular, acuminate to obtuse with usually short and red glandular-tipped and -based hairs 
and usually with a few short, straight, fine, white hairs, the inner surface with fine white hairs especially near the margin. Petals 4, dark pink or often white, broadly obovate or broadly ovate, $6-11 \mathrm{~mm}$ long and $\frac{1}{2}$ to $\frac{2}{3}$ or more as wide with the greatest width usually at, but often above or below, the centre, the petals usually tardily deciduous and occasionally persisting around the fruit. Stamens usually $8,3 \cdot 5-4 \mathrm{~mm}$ long; filament broad, occasionally tending to be joined to the other filament in front of the same petal, usually $0.5-1 \mathrm{~mm}$ long but often difficult to distinguish from the base of the body of the anther; body of the anther 1.5-2.5 mm long, with short stiff hairs or minutely scabrid, occasionally glabrous, the lower $0.25-0.5 \mathrm{~mm}$ flattened especially near the filament and rather variably curved or angled, the apex tapering to the anther-tube; anther-tube rather curved, broad, 1-1.5 $\mathrm{mm}$ long, rarely less, the orifice broad. Ovary covered with dense stiff hairs and glandular-tipped hairs often $0.5 \mathrm{~mm}$ in length, occasionally the hairs of one or other or both kinds sparse; the apex rounded or somewhat tapering to the base of the style, the style $2 \cdot 25-3.5 \mathrm{~mm}$ long, slender, occasionally broader at the base, the lower part bearing straight shining hairs and glandular hairs, rarely the styles 2 . Ovules 2, 1 in each loculus, each suspended from a projection at the top of the axis. Fruit with or without the remains of the flower, obcordate to broadly cuneate, $4.5-5 \mathrm{~mm}$ long and a little less in width. Seeds $3.5 \mathrm{~mm}$ long, shortly cylindrical but somewhat flat on the adaxial side, dark brown with fine spreading hairs, the appendage cream with 3 or more horizontal coils, with a few fine spreading hairs.

Distribution: In dry heath and sclerophyll forest in E. Tasmania and from forests to rocky mountain tops in Victoria and SE. New South Wales. Map 7, see p. 184.

Specimens Examined (Selection Only): New South Wales: Southern Tablelands: Mt Budawang, 12 miles [19 km] E. of Braidwood, Constable 6960, 5.1966 (NSW); Kybean, Costin NSW 131845, 12.1949 (NSW); Kydra, Costin NSW 131844, 10.1948 (NSW); Mt Kosciusko, Findlay 1883 (MEL); Mt Tingiringi, 4500' [1370 m], Bäuerlen 188, 2.1889 (MEL).

VICTORIA: Eastern Highlands: Summit of Pine Mtn, c. 6 miles [10 km] SE. of Walwa, Willis 1.1964 (MEL 1007816, 1007817, NSW); Upper Murray, French (MEL); between the Broken R and Ovens, Mueller (MEL); Benalla, Helms NSW 131875, 10.1901 (NSW); on the Jamieson road c. 30 miles [48 km] from Eildon, Muir 1657, 10.1960 (MEL, NSW); Upper Genoa R near confluence with Yambulla Creek, Wakefield 9.1947 (MEL); Drummer Range, Bäuerlen 396, 2.1887 (MEL); Stringybark Ranges near Mt Useful, 3000-4000' [910-1220 m], Mueller 1.1863 (MEL); Walhalla, Tisdale 8.1883 (MEL 1008282); Erica, Cleaves 9.1944 (CANB 20691, MEL). Brisbane Ranges: Steiglitz, Willis 10.1959 (MEL). Grampians: Grampians, Walter 10.1886 (MEL 1007823, NSW 131876); Grampians, Walter 10.1888 (MEL 1007829); Western slope of the Serra Range, Grampians, D'Alton (MEL).

TaSmania: Boobyalla R, Streleski NSW 131862 (NSW); George Bay, Simson (BRI); Boat Harbour, N. of St Helens, Burbidge 1.1949 (CANB 19122); near St Marys, Phillips 1.1962 (CBG 003014); 8 miles [13 km] from Avoca towards Storys Creek, Phillips 12.1965 (CBG 014865, AD); Near Spring Beach, Phillips 2.1962 (CBG 002997); New Norfolk, Gunn 194/1842, 10.1840 (NSW 131859); Grass Tree Hill, Gunn 194/1842, 10.1840 (NSW 131855); Risdon, Burbidge 1.1949 (CANB 18896); Lindisfarne, Black 10.1921 (AD); Bellerive, Lucas NSW 131865, 10.1924 (NSW); Hobart, Hope 3.1892 (BRI); Hobarton, Gunn 194/1842, 10.1839 (NSW 131858); Sassafras Valley, Hobart, Gunn 194/1842, 10.1840 (NSW 131857); Derwent, Brown 1802-5 (BRI 013046, 013045, NSW 131872); Derwent R, Brown 1802-5 (NSW 131866); Rokeby, Long 8.1931 (CANB 5627); Mt Wellington, Maiden \& Cambage NSW 131860, 1.1902 (NSW); Mt Nelson, Rodway NSW 131854, 11.1916 (NSW); Kingston Beach, Rodway 2.1940 (AD); near Margate, Long 7.1931 (CANB 5616); Port Arthur, Bufton 1893 (MEL); The Neck, Bruny Island, Phillips 11.1965 (CBG 014529, 014530, NSW). Without precise locality: Tasmania, Archer NSW 131873, 131847 (NSW); Van Diemensland, Cunningham (MEL 1007807); in insula van Diemen, Gunn (MEL 1007799); iter australiense, Brown 1802-5 (MEL 1008422, 131852).

This species with its persistent or tardily deciduous calyx-segments is very closely related to $T$. glandulosa. The abundance of glandular hairs inspired the naming of these two species. In $T$. labillardierei they are usually found over most of the plant but in $T$. glandulosa they are usually conspicuous only on the peduncle and calyx-segments. 
28. Tetratheca stenocarpa $J$. H. Willis in Victorian Naturalist $73: 197$ (1957); J. H. Willis, Handb. Pl. Victoria 2: 196 (1973).

Holotype: Mountain Forest on Chandler and Begg's property, 1 mile [1.6 km] east of township, Gembrook, Victoria, W. Waddell 1.xii.1946 (MEL 1008027). IsOTYPE: NSW 125118.

A slender shrub with weak trailing branches to $1.5 \mathrm{~m}$ in length arising from an apparently branched above-ground stock. Stems terete, somewhat irregularly vertically ridged with occasional stout hair-bases extending along the ridges, glabrous, covered with small tubercles or with these produced into small stiff hairs and with occasional short or long setae to $1 \mathrm{~mm}$ in length with broad tubercular bases, the stems $0.6-1.5 \mathrm{~mm}$ broad in the flowering region, terminating in a point, the branching alternate and usually at an acute angle. Leaves alternate, occasionally some lower ones opposite or in whorls of 3, the lowest 5-10 mm long and 4-9 mm wide, almost orbicular to narrowly deltoid, very much modified in the flowering region of the stem until reduced in some specimens to deltoid scales, the upper surface usually glabrous except near the margin where there are minute stiff hairs and large setae or their tubercular bases which give to the margin a dentate or undulate appearance, the lower surface paler but with a few hairs or glandular setae near the base, the margins recurved for the most part, the apex blunt or with a blunt point or sharp seta, the petiole short but often with hairs and glandular setae, attached to a swollen node. Flowers occurring singly or 2 (3) together in the axils of upper, usually modified, leaves, the bracts c. $1 \mathrm{~mm}$ long, brown, linear to lanceolate and with fine white hairs especially on the upper surface. Peduncles 4-10 $\mathrm{mm}$ long with dense, erect, white, shining hairs and numerous erect setae 1-2 mm long, broad at the base and gradually tapering until quite narrow behind a small glandular tip, sometimes lacking a gland, usually red, at least in the upper part, and some glandular hairs which are shorter and somewhat curled, the upper part of the peduncle slightly expanded and ridged and at the top abruptly expanded into a receptacle slightly more than $1 \mathrm{~mm}$ in diameter. Calyx-segments 4, deciduous, $2 \mathrm{~mm}$ long, broadly ovate, acute, with scattered, white, shining, straight hairs and numerous glandular setae, the inner surface with a dense mass of fine hairs near the margin, usually showing on the outside, the lower visible part of each segment not conspicuously thickened but the base attached well inside the top of the receptacle, the upper part of the segment often reflexed. Petals 4, dark pink, pale pink or white, obovate to linguiform, 8-13 mm long and from $\frac{1}{3}$ to $\frac{1}{2}$ as wide with the greatest width in the top $\frac{1}{3}$, deciduous. Stamens 8, rarely $10,3-3.5 \mathrm{~mm}$ long; filament $0.5 \mathrm{~mm}$ or less in length; body of the anther $2-2.5 \mathrm{~mm}$ long with a few hairs, the extreme base flattened and above that, c. $0.5 \mathrm{~mm}$ above the filament, somewhat angled or curved, the apex tapering somewhat to the anther-tube; anther-tube broad, $0 \cdot 7-1 \mathrm{~mm}$ long, the tube variably tapering to a rather broad orifice. Ovary densely to rather sparsely covered with minute stiff hairs and with numerous small slender glandular-tipped hairs; the inner surface with some hairs, the base rather broad, the apex tapering to a style $1 \cdot 7-2.5 \mathrm{~mm}$ long and bearing minute stiff hairs in the lower part. Ovules 4,2 in each loculus, attached in pairs near the centre of the axis. Fruit beaked, ovate, narrowly trapeziform or elliptical, $5-10 \mathrm{~mm}$ or more in length and 2-4 $\mathrm{mm}$ wide. Seeds $2.5 \mathrm{~mm}$ long, obovoid, with a scar at the base or a little above it, brown, shining, with fine scattered spreading hairs, the appendage cream with c. 2 coils directed towards the axis, with sparse, fine, short hairs.

Distribution: On steep hillsides in mountain forest in Victoria. Map 8, see p. 193.

Specimens Examined: Victoria: South Western Part of the Eastern Highlands: Chum Creek road c. 7 miles [11 km] NNW. of Healesville, Constable 5285, 10.1964 (NSW); Upper Yarra, Walter NSW 125117, 9.1876 (NSW); between Gladysdale and Hazeldene, Phillips 10.1964 (NSW 114926); Egg Rock, 2 miles [3 km] E. of Tomahawk Gap, Beenak, Carroll 12.1965 (CBG 015959,015960 ); 6 miles [10 km] N. of Gembrook, Carroll 12.1965 (CBG 017901); Emerald, St John 11.1903 (MEL); Gembrook, Waddell 12.1946 (MEL 1008027, NSW 125118); Gembrook Ranges, Walter 9.1881 (MEL); Forest Road junction on Ripons Creek, c. $5 \frac{1}{2}$ miles [9 km] $\mathrm{N}$. of Labertouche, Willis 10.1952 (MEL); Labertouche State Forest, between Latrobe and Bunyip Rivers, Galbraith 11.1964 (AD).

This species is obviously related to $T$. ciliata which it resembles in many ways. It can be readily distinguished by the numerous long setae on the peduncles. 
29. Tetratheca ciliata Lindl. in Mitchell, Three Exped. 2: 206 (1838); W. J. Hooker, Icones Plant. 3: t. 268 (1840); J. D. Hooker in J. Bot. (Hooker) 2: 408 (1840); Walpers, Repert. Bot. Syst. 1: 249 (1842), 2: 770 (1843); Steetz, Familie Tremandreen: 11 (1853); Schuchardt, Syn. Tremandr.: 32 (1853); J. D. Hooker, Fl. Tasmaniae 1: 34 (1885); F. Mueller, Pl. Indig. Colony Victoria 1: 181 (18601862); Bentham, Fl. Austral. 1: 130 (1863) incorrectly synonymizing $T$. bauerifolia; Spicer, Handb. Pl. Tasmania: 103 (1878); F. Mueller, Native Pl. Victoria 1: 62 (1879); F. Mueller, Fragm. 12: 7 (1882); F. Mueller, Syst. Census Austral. Pl. 1: 9 (1882); F. Mueller, Second Syst. Census 1: 15 (1889); Tate, Handb. Fl. Extratrop. South Australia: 37 (1890); Rodway, Fl. Tasmania: 10 (1903); Ewart et al., Field Nat. Club Census Pl. Victoria: 40 (1923); J. M. Black, Fl. South Australia 2: 346 (1924); Ewart, Fl. Victoria: 712 (1931); J. M. Black [ed. 2] 2: 503 (1948); Turrill in Bot. Mag.: n.s. t. 62 (1949); Curtis, Stud. Fl. Tasmania: 56 (1956); J. H. Willis, Handb. Pl. Victoria 2: 95 (1973).

TYPE: On the bank of . . . rivulet which I named the Chetwynd [Victoria], Mitchell 277, 5.viii.1830. IsOTYPE: MEL 1008072.

Synonymy: Tetratheca ciliata var. glabra Schuchardt, Syn. Tremandr.: 33 (1853). TyPE: A specimen, MEL 1008396, labelled " $\beta$ glabra mihi" by Schuchardt is certainly a Type though it lacks locality, collector and date. Another specimen, MEL 1008395, without information is labelled " $\beta$ glabra" in Schuchardt's handwriting as also is MEL 1008357 which also has "Ad limit orient. colon Nov. Holl. austr. Octbr 48" in Schuchardt's hand. The specimen, Ad limites orientales coloniae Nov. Holl. austr, Mueller 10.1848 (MEL 1008392), is probably a duplicate of this and, from the appearance of the specimens, it is possible that the specimen, In vallibus versus Mount Disappointment, Mueller 10.1852 (MEL 1007397), is a duplicate of MEL 1008396.

Tetratheca ciliata var. alba Ewart, Fl. Victoria: 713 (1931). TyPE: National Park, [Wilsons Promontory, Victoria], 1909. I have not been able to locate this specimen.

A slender shrub up to $1 \mathrm{~m}$ in height, usually weak-stemmed and straggling with several or numerous branches arising, often several together, from a branched often stout woody base. Stems terete, irregularly vertically ridged, the hairs often rather dense, spreading, usually erect, of varying lengths in the one area (fig. 1), from very short to $1 \mathrm{~mm}$, white to fawn, shining, rarely with a few, red, glandular hairs with small dark tips, occasionally the stems glabrous but then covered with minute tubercles, the stems $0.5-1.2 \mathrm{~mm}$ broad in the flowering region, the branching alternate or occasionally opposite, with the branches somewhat spreading. Leaves alternate, opposite or often in irregular whorls of 3 , more rarely in regular whorls of 3,4 or 5 , very variable in size and shape even on one branch, often much narrower and smaller in the flowering region of the stem, especially on the lower part of the plant often 15 or almost $20 \mathrm{~mm}$ long and up to $15 \mathrm{~mm}$ wide but even on the same specimen they may be $2 \mathrm{~mm}$ long and $1 \mathrm{~mm}$ wide, varying from narrowly elliptical to almost orbicular, tending to be rhomboidal or obtrullate, usually tapering at the extreme base, the upper surface glabrous or with scattered, fine, straight hairs especially just above the petiole, often with some stout seta-like hairs near the margin, occasionally with dense hairs of this kind, the lower surface much paler, glabrous or rarely with fine erect hairs or seta-like hairs on the midrib, the margins flat or with the edges recurved or revolute, usually undulate, the apex lacking a point, the petiole very distinct, $1 \mathrm{~mm}$ long, rather swollen at the base and/or attached to a swollen node. Flowers occurring singly or often 2 (3) together in the axils of upper leaves, the bracts minute to $1.5(2) \mathrm{mm}$ long, usually dark brown, concave, linear to broad-lanceolate, obtuse to long-acuminate and with fine white hairs especially near the tip, rarely the flower with a bract in the middle of the peduncle. Peduncles 3-12 mm long, usually dark-coloured, with numerous white, erect, shining hairs and at least a few, often many, slender, though often broad-based, curved darkpurple glandular-tipped hairs more than $0.5 \mathrm{~mm}$ but usually less than $1 \mathrm{~mm}$ long, the upper part of the peduncle expanded and somewhat ridged and at the top rather abruptly expanded into a receptacle $1-1.5 \mathrm{~mm}$ in diameter. Calyx-segments 4 , deciduous, $1.5-3 \mathrm{~mm}$ long, usually broadly ovate, obtuse to acuminate with scattered white shining, straight hairs and usually at least a few slender, purple, glandular- 
tipped hairs up to $1 \mathrm{~mm}$ in length, the inner surface with fine white hairs especially dense near the margin, the lower visible part of each segment not conspicuously thickened but the base attached inside the top of the receptacle, the upper part of the segment and more usually most of it invariably strongly reflexed. Petals 4, dark pink, pale pink or occasionally white, varying from obovate to broadly or narrowly linguiform, 6-18 $\mathrm{mm}$ long and from $\frac{1}{3}$ to $\frac{1}{2}$ as wide, rarely wider, with the greatest width usually in the upper $\frac{1}{3}$, deciduous. Stamens $8,2 \cdot 8-4.5 \mathrm{~mm}$ long; filament $0.5 \mathrm{~mm}$ or less in length; body of the anther 2-3 mm long, glabrous or with some short stiff, often stout, hairs, the extreme base somewhat flattened and slightly or strongly curved at $0.5 \mathrm{~mm}$ or less above the filament, the apex tapering somewhat into the anthertube; anther-tube rather broad, less than 0.5 to $0.8 \mathrm{~mm}$ in length, variably tapering to a rather broad orifice. Ovary densely covered with short, velvety, white hairs and usually with some small, slender, glandular-tipped hairs, rarely almost glabrous, the inner surface with some hairs, the base rather broad, the apex usually tapering into a style $2-2.5 \mathrm{~mm}$ long with the lower part covered with dense stiff hairs. Ovules 4,2 in each loculus, attached in pairs above the centre of the axis. Fruit from the few specimens seen very variable in size and shape, 4-8 $\mathrm{mm}$ long and 4-5 $\mathrm{mm}$ wide, obovate to broadly obovate, the apex emarginate or beaked, the seeds leaving no thickening on the axis. Seeds 2-3 mm long, obovoid with a scar just above the base, brown, shining with fine, scattered, spreading hairs, the appendage cream with sparse fine hairs, with 2 spreading coils directed towards the axis.

Distribution: In a variety of habitats from sandy coastal heath in Tasmania to mont ane and dry inland areas of south-eastern mainland States. Map 8, see below.

MAP 8

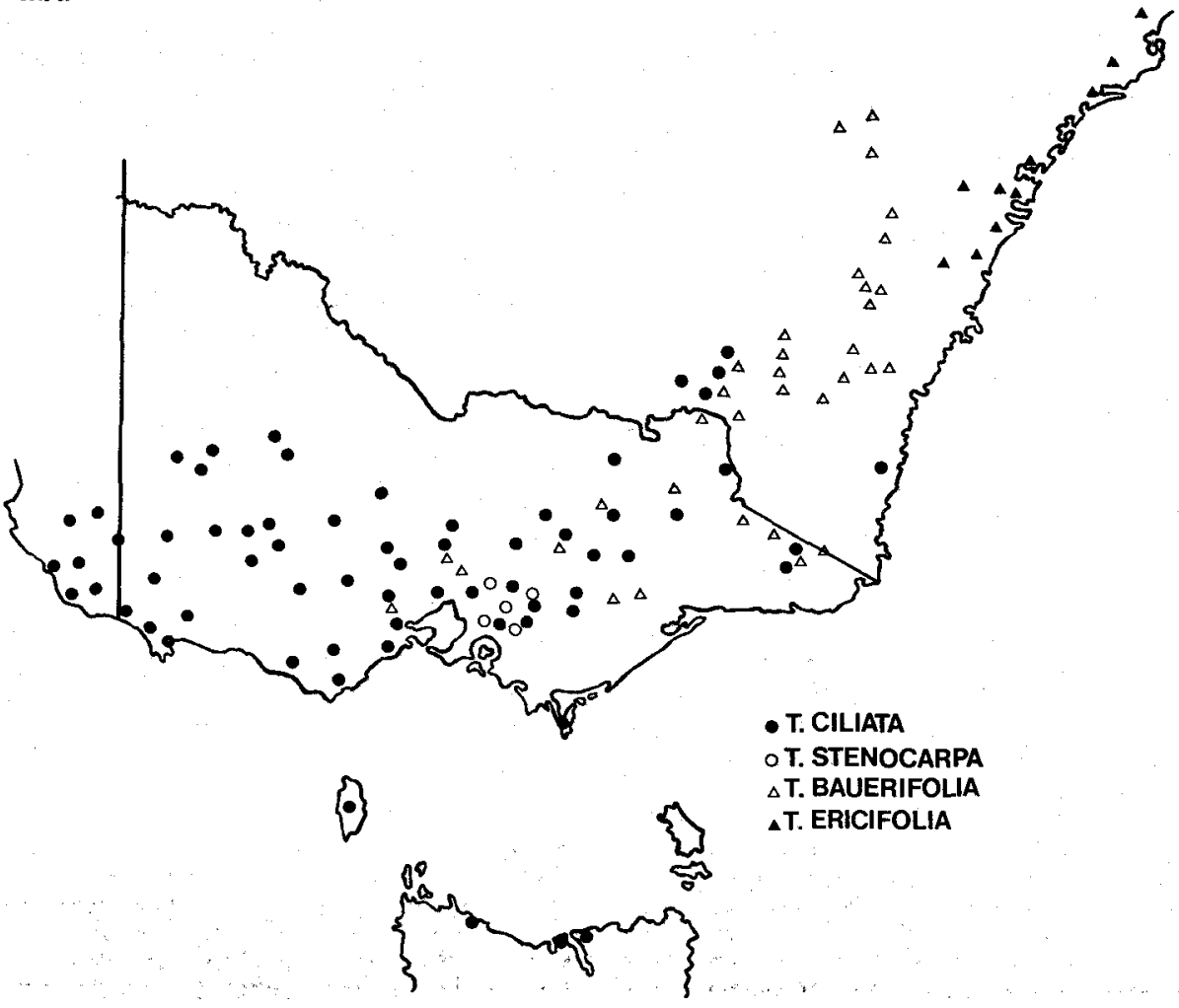


Specimens Examined (Selection ONly): New South Wales: South Coast: Cobargo, Tilba, MacGillivray per A. Morris 1144 (NSW). Southern Tablelands: Batlow, Boorman NSW 19691, 10.1916 (NSW, BRI); Bago State Forest, Batlow, Giles NSW 131790, 10.1962 (NSW); Tumbarumba, Dwyer 1448, 11.1927 (NSW); near base of Mt Kosciusko, 10.1887 (MEL). South Western Slopes: Near Adelong, Garland 11.1880 (MEL); Tumut, Mechan NSW 131800, 9.1895 (NSW); 5 miles [8 km] SW. of Carabost, Logan NSW 84023, 11.1966 (NSW); Jingellic, Boyle NSW 131801, 10.1936 (NSW).

VICTORIA: Eastern Highlands and Eastern Port Phillip District: Mt Granya, Mueller (NSW 131818); 5 miles [8 km] from Stanley towards Mt Stanley, Canning 10.1967 (CBG 024226); Kiewa Power Station, Di Giovanni 97, 10.1961 (AD, MEL); Reservoir road, Mt Buffalo, Briggs NSW 131817, 12.1952 (NSW); Delegate R, Merrah 1887 (MEL 1008197, 1008292); sources of the Broadribb [Brodribb] R, Merrah 8.1887 (MEL); Dargo R watershed area, Stirling 150, 10.1882 (MEL); in vallibus versus Mt Disappointment, Mueller 10.1852 (MEL 1008396, 1008397); Warrandyte, Meebold 21707, 11.1936 (NSW); Dandenong Ranges, 1853 (MEL); Emerald, McLennan 10.1906 (MEL); Oakleigh, Morrison 10.1894 (CANB 129296); Caulfield (BRI); Port Phillip, Brown 1802-1805 (BRI, MEL, NSW 131807, 131810); Walhalla Road, Gippsland (MEL). Wilsons Promontory: Track to Sealers Cove, Phillips 11.1961 (CBG 002999); on the Lighthouse track near Frasers Creek, Muir 917, 11.1959 (MEL). Western Highlands: St Arnaud, Maroske 10.1958 (MEL); near Bendigo, Gauba 10.1952 (CBG 002930, NSW); near Stawell, Williams 159, 8.1960 (AD); Moyston, Sullivan 11.1871 (MEL); Ballarat, Spence 1884 (MEL); near Daylesford, Gauba 10.1952 (CBG 002931); Mt Macedon, Hartley 0316, 11.1946 (CANB); $3 \frac{1}{2}$ miles [6 km] from Anakie Junction towards Ballan, Carroll 9.1966 (CBG 018110). Wimmera and Little Desert: Donald, Curdie (MEL); Wimmera, Dallachy (MEL); 20 miles [32 km] S. of Nhill, Ackland 30, 9.1963 (MEL, BRI); Little Desert, Western Section, Henshall NSW 131821, 9.1969 (NSW). Grampians: 3 miles [5 km] from Golton Gorge towards Flat Rock, Phillips 10.1966 (CBG 019505); Black Range, Audas 10.1929 (MEL); Mt William, Wilhelmi 1857 (MEL); S. of Halls Gap, Muir 782, 9.1959 (AD, BRI, CANB, MEL, NSW); Chetwynd, Mitchell 277, 8.1830 (MEL 1008072); W. side of Mirranatwa Gap, Serra Range, S. of Halls Gap, Rodd NSW 131831, 8.1969 (NSW). Western Coastal Plain: Wilkin, 12 miles [19 km] SW. of Casterton, Aston 799, 10.1960 (MEL); along main Portland-Nelson road, 3 miles [5 km] SE. of Gorae West, Aston 727, 10.1960 (MEL); Heywood, Renfrey (MEL); Geelong, Bracebridge-Wilson 1888 (MEL); Ćolac Ranges, Mariner (MEL); between Aireys Inlet and Anglesea, Carroll 9.1966 (CBG 018108); Curdies R, Allen 1892 (MEL); Apollo Bay, Whibley 81, 10.1957(AD). Without precise locality: Ad limites orientales coloniae Nov. Holl. austr., Mueller 10.1848 (MEL 1008357, 1008392); MEL 1008395.

South Australia: South East District: Near the gap on Naracoorte-Bordertown road, Hunt 8.1961 (AD); Avenue Range, Lucindale, Carrodus 8.1956 (AD); Penola Forest Reserve, Hunt 9.1965 (CANB 172490,172489 , AD); towards Rivoli Bay, Mueller 10.1848 (MEL); Mt Burr Forest Reserve, Wilson IBW 480, 8.1966 (AD, CANB); Mons Gambier, Mueller (MEL); Lake Bonney, Wehl 1888 (MEL).

TASmania: King Island, Bass Strait, Spong NSW 131843, 1876 (NSW); Sisters, Rocky Cape, Gunn 648/1842, 8.1838 (NSW 131840); West Head, Georgetown, Gunn 648, 10.1844 (NSW 131842); near Port Sorell, 917 (MEL 1007661).

A specimen, W. Australia, Walter (NSW 131839) undoubtedly belongs to this species but I suspect it is incorrectly labelled, as Walter has collected other specimens of this species in Western Victoria. I also hesitate to accept the locality Mt Lofty [South Australia] (MEL 1008312) as correct.

$T$. ciliata is characterized by its conspicuously refiexed calyx and its stems where hairs of varying length are found in one area. It has close affinity with $T$. stenocarpa but relationship with other species is obscure.

30. Tetratheca ericifolia Sm., Exot. Bot. 1: 37, t. 20 (Mar. 1805). The concept of this species became much enlarged soon after its original description was published and it is possible that even the early references may include other species. I have therefore placed a list of references, with comments, at the end of the treatment of this species.

Holotype: Port Jackson, New South Wales, Mr White 1792. There is a sheet in the Smith Herbarium, Linnean Society, annotated by Smith as Tetratheca ericifolia. It bears seven separate plant pieces. Although Smith described the calyx as smooth, three pieces on the Type sheet have calyces with glandular hairs. As Smith described fruits from these pieces they are obviously Holotype material. Specimens from herb. Hook. (K) and herb. Goodenough (K) are duplicates. Miss Helen Aston reports that the specimen from Hooker's herbarium agrees with the specimen, 
N. end of Eurabba road, Duffys Forest, Coveny 600, 10.1968 (NSW 112375). Normally this species has glandular hairs on the calyx and indeed this is a useful diagnostic character but occasionally as in collections by Robert Brown (MEL 1007770, NSW 125220) and Sieber (MEL 1008385) the calyx lacks them. I have seen only photographs of the Type material.

A diffuse or compact shrub usually $15-40 \mathrm{~cm}$ in height, with a stout or branched stock, with numerous stems arising at the top of the stock, branching several times near the base of the plant, occasionally with numerous branches in the upper part. Stems terete, somewhat 4-angled below the nodes, covered with pale brown, regularly antrorse, tubercle-based setae c. $0.5 \mathrm{~mm}$ long (fig. 1), the stems $0.3-1.2 \mathrm{~mm}$ broad in the flowering region, the branching usually alternate, occasionally several branches arising together. Leaves in whorls of 4-6, occasionally a few alternate or opposite at the base of a branch, (3-) 5-7 (-10) mm long and c. $1 \mathrm{~mm}$ wide, occasionally 1.5 $\mathrm{mm}$ near the base, often rather recurved, linear or tending to taper towards the apex, the upper surface with tubercles at least near the margins or more rarely smooth, often bearing short, stout, antrorse hairs and with other scattered, antrorse to almost erect short, stiff hairs, the lower surface paler, glabrous, often with setae on the broad midrib, the margins revolute but some of the lower surface usually showing especially near the base and usually most of the midrib showing, the apex obtuse but usually with a minute often recurved point, the petiole short but usually distinct. Flowers occurring singly in the leaf-axils, the bracts usually up to $1 \mathrm{~mm}$ in length, pale to mid-brown, broad-lanceolate or oblanceolate, concave, usually with some hairs on the upper surface near the tip and appearing to be on the base of the peduncle. Peduncles $10 \mathrm{~mm}$ to more than $25 \mathrm{~mm}$ in length in the mature flower, dark-coloured and glabrous, the upper part somewhat expanded and the extreme upper part often abruptly expanded to form a receptacle c. $1 \mathrm{~mm}$ in diameter. Calyx-segments 4 , deciduous, dark-coloured, (1-) $1.5(-2) \mathrm{mm}$ long, ovate to broadly ovate, obtuse to acuminate, with red, small-tipped, broad-based, glandular hairs $1 \mathrm{~mm}$ long, rarely glabrous, the inner surface with hairs inside the margin, the base of each segment thickened especially in the centre over the rim of the receptacle, the segment attached inside the rim. Petals 4, dark pink, rarely white, narrowly to broadly obovate to narrowly or broadly linguiform, $5-12.5 \mathrm{~mm}$ long and usually c. $\frac{1}{2}$ as wide with the greatest width usually well towards the apex, deciduous. Stamens 8, 2.75 mm long; filament rather broad, c. $0.5 \mathrm{~mm}$ or less in length; body of the anther $1.5-2 \mathrm{~mm}$ long, glabrous, the lower $0.25 \mathrm{~mm}$ flattened and above that the body quite strongly curved, the upper part contracting into the anther-tube; anther-tube tapering, curved, $0.3-0.75 \mathrm{~mm}$ long with a narrow orifice. Ovary glabrous or with a few shining hollow broad-based hairs on the broad base, the apex tapering to a rather stout glabrous style 1-1.5 mm long. Ovules 4, 2 in each loculus, attached above the centre of the axis. Fruit beaked, elliptical to somewhat cuneate or broadly cuneate to almost oblong, 6-8 mm long and $\frac{1}{2}$, or more or less, as broad with the seeds leaving little or no scar on the axis. Seeds $3-4 \mathrm{~mm}$ long, cylindrical but flat on the adaxial surface with a scar only near the base, oblique at the base, brown, with very fine sparse spreading hairs, the appendage cream, with 4 coils beyond the seed, glabrous.

Distribution: In sandy heath or forest on the lower North and Central Coast regions and the southern part of the Central Tablelands of New South Wales. Map 8, see p. 193.

Specimens Examined (Selection OnLy): New South Wales: North Coast: Nabiac airstrip, Coveny 674, 12.1968 (NSW); Cape Hawke, Bulladelah, Fawcett 138, 12.1884 (MEL); Nelson, Bay, Lithgow 155, 5.1965 (NSW). Central Coast: Gosford, Purser NSW 125197, 9.1899.(NSW); Mt White, Chippendale NSW 125218, 8.1953 (NSW); Wondabyne, Blakely NSW 125195, 9.1938 (NSW); Pearl Beach, Groot Obbink 11.1965 (CBG 013355); McCarrs Creek, The Duckhole, Mair NSW 125208, 7.1952 (NSW); Berowra, Williams 11.1961 (CBG 002927); Glenorie, Blakely NSW 125191, 9.1938 (NSW); N. end of Eurabba road, Duffys Forest, Coveny 600, 10.1968 (NSW 112375); Tumble-Down-Dick, Blakely NSW 125226, 9.1937 (NSW); Hornsby, Burgess 9.1961 (CBG 006814, 002988); Pennant Hills, Fraser NSW 125199, 9.1934 (NSW); Lindfield, Dixon NSW 125206, 9.1903 (NSW); Brookvale, Manly, Cheel. NSW 125203, 9.1898 (NSW); Manly, Siegert 220, 11.1884 (MEL); Springwood, Cross NSW 125212, 3.1934 (NSW); Woodford, Burgess 9.1959 (CBG 002929, 006806); Middle Harbour, Port Jackson, Cleland 2.1910 (AD); Northbridge, Blakely NSW 125224, 9.1934 (NSW); Sydney, Mossman 44 (BRI 013053 in part); Port Jackson, Brown 1802-5 (MEL 1007770, NSW 125220); 
South Head, Port Jackson, Mueller 7.1855 (MEL); Dover Heights, Rose Bay, Black 77.001 (I), 5.1926 (MEL); Rose Bay, Helms NSW 125223, 9.1900 (NSW); Engadine, Williams NSW 114925, 11.1960 (NSW); between Appin and Bulli Pass, Cross NSW 125209, 1.1933 (NSW). Central Tablelands: Mittagong, Dixon NSW 125225 (NSW); Argyle County, 830 (MEL 1007745). Without precise locality: New Holland, Sieber 234 (MEL 1008385).

The following references apply, apply in part or do not apply to this species. Persoon, Syn. Pl. 1: 419 (Apr.-Dec. 1805) 'ericaefolia' based on a Née specimen, not necessarily of this species, which I have not seen; Rudge in Trans. Linn. Soc. London 8: 295 (1807) 'ericaefolia'; J. E. Smith in Rees Cycl. 35 (2): (1817); Steudel, Nomencl. Bot.: 828 (1821) as 'ericaefolia Thib. Pers.' with 'T. ericaefolia Sm. (et? Pers.)' as a synonym of T. pilosa Labill.; Candolle, Prodr. 1: 343 (1824); Sprengel, Syst. Veg. 2: 214 (1825) 'ericaefolia'; J. D. Hooker in J. Bot. (Hooker) 2: 408 (1840) 'T. ericina Sm.'; Steudel, Nomencl. Bot. [ed. 2] 2: 673 (1841) 'ericaefolia'; A. Gray in Hooker's J. Bot. Kew Gard. Misc. 4: 200 (1852) referring to the solitary ovules of $T$. ericifolia 'ericaefolia' therefore unlikely to be this species; Schuchardt, Syn. Tremandr.: 27 (1853) 'ericaefolia' including other species in the description; F. Mueller, Pl. Indig. Colony Victoria 1: 182 (1860-1862) including all Eastern Australian material known to Mueller other than $T$. ciliata; Bentham, Fl. Austral. 1: 131 (1863) probably with other species included and incorrectly including $T$. rubioides A. Cunn. as a variety; Woolls, Pl. Indig. Neighb. Sydney: 11 (1880); F. Mueller, Fragm. 12: 6 (1882) including T. pilosa, T. thymifolia, T. subaphylla and T. labillardierei (as T. glandulosa); F. Mueller, Syst. Census Austral. Pl. 1: 9 (1882) including other species as other states are given in the distribution; Tate in Trans. Proc. Roy. Soc. South Australia 6: 150 (1883) referring to T. insularis; C. Moore, Census Pl. New South Wales: 5 (1884); F. Mueller, Key Syst. Vict. Pl. 2: 9 (1885) and 1: 155 (1887-8) but the species is not found in Victoria; F. Mueller, Second Syst. Census 1: 15 (1889) including other species; Tate, Handb. FI. Extratrop. South Australia: 37 (1890) referring to composite material not including $T$. ericifolia; Moore \& Betche, Handb. Fl. New South Wales: 36 (1893) including all N.S.W. species known to them other than T. juncea; Maiden \& Betche, Census N.S. Wales P1.: 119 (1916) including all N.S.W. species known to them other than T. juncea; J. M. Black, Fl. South Australia 2: 346 (1924), 4: 592 (1929) \& [ed. 2] 2: 503 (1948) referring to $T$. insularis; Ewart, Fl. Victoria: 713 (1931) referring to species other than T. ericifolia and T. rubioides; Beadle, Evans \& Carolin, Handb. Vasc. Pl. Sydney Distr.: 147 (1963) including T. rupicola; Beadle, Evans \& Carolin, Fl. Sydney Region: 172 (1972) including T. rupicola; Beadle, Stud. Fl. NE. New South Wales: 156 (1973) referring to T. ericifolia only; J. H. Willis, Handb. Fl. Victoria 2: 195 (1973) including other species especially $T$. bauerifolia.

This species is characterized by its long slender peduncles and the glandulartipped hairs which usually cover the small calyx. It can be separated from other species with whorled linear leaves by its stem-pubescence of regularly antrorse setae.

31. Tetratheca bauerifolia $F$. Muell. ex Schuchardt, Syn. Tremandr.: 29 (1853) 'baueraefolia'; Turrill in Bot. Mag.: n.s. 62 (1949).

SYNTYPES: In Australas. meridionali in monte Mount Disappointment prope Melbourne [Victoria], Mueller 10.1852, herb. Sonder (3 specimens). I have not seen these specimens but MEL 1007717 is probably a duplicate and perhaps also MEL 1007718 and MEL 1008376.

A compact shrub usually up to $30 \mathrm{~cm}$ in height with several or many branches from a slender or robust branched stock which appears to root at the nodes. Stems terete or somewhat quadrangular below the nodes and usually rather irregularly vertically ridged, with rather dense, short, usually curved or curled, white to fawn and shining hairs, occasionally some red hairs with small glandular tips and usually some scattered, rarely dense, broad-based usually antrorse setae up to $1 \mathrm{~mm}$ in length, the stems $0.5-1.5 \mathrm{~mm}$ broad in the flowering region, often with several branches arising together, sometimes only one or two at each node. Leaves in whorls of 4-6, (4-) 6-8 $(-10) \mathrm{mm}$ in length and 2-3 $\mathrm{mm}$ wide, narrowly elliptical to 
obovate, tending to recurve and then incurved towards the apex, the upper surface rarely glabrous, usually with short, stiff hairs at least near the apex and occasionally with tubercle-based setae near the margin, on the Mt Buffalo specimen with numerous long shining hairs; the lower surface paler, usually glabrous but occasionally with short stiff hairs or setae especially on the midrib, the margins flat, recurved or loosely revolute, the apex with a small blunt or rarely sharp point, the petiole short or negligible. Flowers occurring singly, occasionally 2 together, in the axils of upper leaves, the bracts c. $1 \mathrm{~mm}$ long, usually light brown, concave, linear to broadlanceolate and with a fringe of hairs on the upper surface. Peduncles lengthening as the flower matures, $10-20 \mathrm{~mm}$ long in the mature flower, dark-coloured, usually with scattered shining spots, glabrous or very rarely with a few erect, shining, white hairs near the top, the upper part often hooked, broadening at the top and again, often quite abruptly, expanding to form a receptacle $1 \mathrm{~mm}$ in diameter. Calyxsegments 4, deciduous, often dark-coloured, 1.5-2 mm long, ovate to broad-ovate, obtuse, acute or very shortly acuminate, glabrous except rarely for a few fine hairs, with scattered shining spots, the inner surface with fine white hairs near the margin especially at the tip, the base of each segment attached inside the top of the receptacle but not or scarcely thickened above the edge of the receptacle. Petals 4, dark pink, broadly to narrowly obovate or contracted abruptly towards the base so as to be broadly linguiform, 6-10 $\mathrm{mm}$ long and from less than $\frac{1}{2}$ to $\frac{2}{3}$ or more as wide with the greatest width usually above the centre, deciduous. Stamens usually $8,2 \cdot 5-3.5 \mathrm{~mm}$ long; filament less than 0.25 to $0.75 \mathrm{~mm}$ in length; body of the anther $1.5-2 \mathrm{~mm}$ long, glabrous, minutely scabrid or with short stiff hairs, the lower $0.5 \mathrm{~mm}$ or even $1 \mathrm{~mm}$ flattened and the body then slightly or strongly curved above this and tapering at the apex to the anther-tube; anther-tube rather broad, somewhat curved, less than $0.25-0.75 \mathrm{~mm}$ in length and variably tapering to a broad or narrow orifice. Ovary densely covered with short, stiff, antrorse hairs or with longer shining hollow hairs usually $0.5(-1) \mathrm{mm}$ or less in length, often also with slender glandular-tipped hairs, or glabrous, often with only a few hairs of one or more types, the base of the ovary broad, the apex rounded, the slender style 1.75-2 $\mathrm{mm}$ long, the base glabrous or with short stiff hairs. Ovules 4,2 in each loculus, attached in pairs on the upper part of the central axis. Fruit cordate, shortly cuneate to broadly obovate, 5-8 mm long and $5 \mathrm{~mm}$ broad, beaked with the remains of the style, the placenta slightly broader than the rest of the septum. Seeds not seen.

Distribution: In exposed rocky areas in open forests at altitudes of over $600 \mathrm{~m}$, and usually over $1000 \mathrm{~m}$, in the Central and Southern Tablelands of New South Wales, and in the Eastern Highlands and Brisbane Range area of Victoria. Map 8, see p. 193.

Specimens Examined (Selection Only): New South Wales: Central Tablelands: 'Near Dubbo', sources of the Macquarie R, Curran 1882 (MEL); Hill End, Lauterer (MEL); Mullion Range State Forest, Giles NSW 119702, 10.1955 (NSW); Bathurst (MEL 1007757); Rocky Top, 3 miles [5 km] W. of Kanangra Tops, Johnson NSW 119687, 10.1948 (NSW); Taralga-Wombeyan Caves, Moore 2639, 10.1953 (CANB, NSW). Southern Tablelands: 10 miles [16 km] from Goulburn towards Crookwell, Shoobridge 10.1967 (CBG 024471); Kingsdale, 4 miles [6 km] N. from Goulburn, Lumsden NSW.119711, 10.1906 (NSW); Goulburn-Bungonia, Moore 2585 , 9.1953 (NSW); Bungendore, McGillivray 613, 10.1957 (NSW); Two Sticks road, 1 mile [1.6 km] from Cotter Road, A.C.T., D'Arnay 11.1961 (CANB 126447, 126448, 126449, 126453); on edge of Coree Flat, A.C.T., Canning 10.1967 (CBG 021082); Uriarra-Brindabella road near Mt Franklin turnoff, A.C.T., Rodd \& Coveny 2570, 12.1967 (NSW); between Bulls Head and Mr Franklin, A.C.T., Darbyshire 71, 12.1960 (CANB, BRI, MEL, NSW); Valley of the Tumut (MEL 1008131); Braidwood-Nerriga road, Moore 1867, 10.1952 (CANB 27022, 54147); Currockbilly Mtn near Braidwood, Boorman NSW 119690,9.1915 (NSW); Mongarlowe R, c. $1.6 \mathrm{~km}$ S. of Mongarlowe, De Nardi 542, 11.1970 (NSW); Captains Flat, Carriage 11.1965 (CBG 013084); Tumbarumba, Bull (MEL); Tinderry Mtns, Costin NSW 119689, 10.1948 (NSW); 2 to 3 miles [3-5 km] from Tooma Dam on Khancoban Road, Phillips 1.1965 (CBG 008940); sources of the Genoa R, Clarke 1887 (MEL).

VICtoria: Eastern Highlands: Mt Buffalo, Cambage 3743, 1.1913 (NSW); E. of Lake Catani, Briggs NSW 119707, 12.1952 (NSW); Omeo-Corryong Highway, bridge at Gibbo R, Ackland 195, 11.1964 (MEL); summit of Turnback Mtn, Snowy R, Howitt 455, 1882 (MEL); Wulgulmerang Post Office towards Buchan, Carroll 12.1965 (CBG 015993); Upper Bendoc, Howitt 519, 1882 (MEL); Cann Valley, Sayer 1887 (MEL 1008250, 1008246); Kilmore, Dwyer NSW 119701, 1918 (NSW); scrubby hills near Mt Disappointment, Mueller 10.1852 (MEL 
1007718, 1007717); Mt Disappointment, Mueller (MEL 1008376); Kinglake, Stokes 9.1962 (MEL); McAllister R (MEL 1007755). Brisbane Ranges: Meredith, Johnson 1884 (MEL); Steiglitz, Willis 10.1959 (MEL); 3 miles [5 km] from Anakie Junction towards Ballan, Carroll 9.1966 (CBG 018637).

Bentham, Fl. Austral. 1: 130 (1863), includes this species in T. ciliata while Mueller, Pl. Indig. Colony Victoria 1: 182 (1860-1862) and Fragm. 12: 6 (1882), includes it in $T$. ericifolia where his text shows that he has not considered it distinct from $T$. thymifolia which he also includes in T.ericifolia. This species is that referred to by Burbidge \& Gray, Fl. Austral. Cap. Territory: 242 (1970), as Tetratheca aff. ericifolia $\mathrm{Sm}$.

$T$. bauerifolia, although so often confused with other species, is quite distinct. It can usually be recognized at a glance by its whorled non-linear leaves and slender usually hooked peduncles. The stem-pubescence of short, usually dense, curved or curled hairs is characteristic. The calyx and peduncle in this species resemble those of the $T$. pilosa group but the significance of this is rather obscure.

\section{Tetratheca rupicola $J$. Thompson sp. nov.}

Holotype: Wentworth Falls, Blue Mountains, New South Wales, I. Bowden \& R. Coveny 3372, 24.xi.1970 (NSW 114384).

ISOTYPE: $\mathrm{K}$.

Fruticulus $20-40 \mathrm{~cm}$ altus. Rami pilis $0 \cdot 5-1 \mathrm{~mm}$ longis, basibus tubercularibus, irregulariter antrorsis, vestiti. Folia verticillata verticillis 4-5 (6)-foliatis, $5-15 \mathrm{~mm}$ longa, linearia. Pedunculi plerumque $7-13 \mathrm{~mm}$ longi; receptaculo $1-1.5 \mathrm{~mm}$ diametro. Flores 4-meri. Stamina filamentis $0.5 \mathrm{~mm}$ longis; tubis antherarum attenuatis, $0.25-0.5 \mathrm{~mm}$ longis. Ovarium pilis densis nitidis vestiti vel ex parte vestiti vel glabrum; ovulis 4 .

A compact, or occasionally diffuse, shrub $20-40 \mathrm{~cm}$ in height with a stout often branched stock and stems often branching several times near the base, the stock horizontal and rhizomatous and the plants over an area appearing so uniform as to indicate connecting rhizomes. Stems terete or quadrangular with sparse to numerous, white or grey, fine, tubercle-based hairs $0.5-1 \mathrm{~mm}$ long, the hairs tending to be antrorse but many twisted and irregularly directed, or glabrous with the tubercles conspicuous, the stems $0 \cdot 6-1 \cdot 2 \mathrm{~mm}$ broad in the flowering region, the branches erect, alternate, opposite or several arising together. Leaves usually in whorls of 4 or 5 , occasionally 6 , rarely a few alternate, opposite or in threes near the base of branches, $5-15 \mathrm{~mm}$ long and 1-1.5 mm broad, linear, tending to recurve and tapering towards the apex, the upper surface with scattered large tubercles from the remains of tubercle-based hairs, occasionally with a slender, shining hair attached, especially on young growth, the lower surface little seen, then glabrous, the midrib glabrous, the margins closely revolute but often exposing the midrib, the apex rather acute and with a, usually recurved, often pungent, point, the petiole short or negligible. Flowers occurring singly in the leaf-axils, the bracts usually $1.5 \mathrm{~mm}$ long, pale, concave, linear-lanceolate, long-acute or acuminate. Peduncles usually 7-13 mm long, glabrous or with fine, spreading, curved, white hairs, the upper part thickened and widening again at the top to form a receptacle $1-1.5 \mathrm{~mm}$ in diameter. Calyxsegments 4 , deciduous, $1 \cdot 5-3.5 \mathrm{~mm}$ long, narrowly or broadly ovate to obovate, glabrous or with few or many fine, white, curved hairs, rarely, and usually at lower altitudes, with pale or red red-tipped broad-based glandular hairs, the inner surface with dense fine hairs near and on the margin, showing from the outside, the lower part of each segment thickened especially in the centre above the margin of the receptacle. Petals 4, dark pink, occasionally pale pink and varying shades of pink, obovate to broadly or narrowly linguiform, $6-15 \mathrm{~mm}$ long and $\frac{1}{3}$ to almost $\frac{1}{2}$ as wide with the greatest width in the upper $\frac{1}{2}$ usually the upper $\frac{1}{3}$, deciduous. Stamens $8,2.5-3.5 \mathrm{~mm}$ long; filament broad, $0.5 \mathrm{~mm}$ long; body of the anther $1.75-2.5 \mathrm{~mm}$ long, glabrous, the extreme lower $0.3 \mathrm{~mm}$ flattened and above that the body slightly 
MAP 9

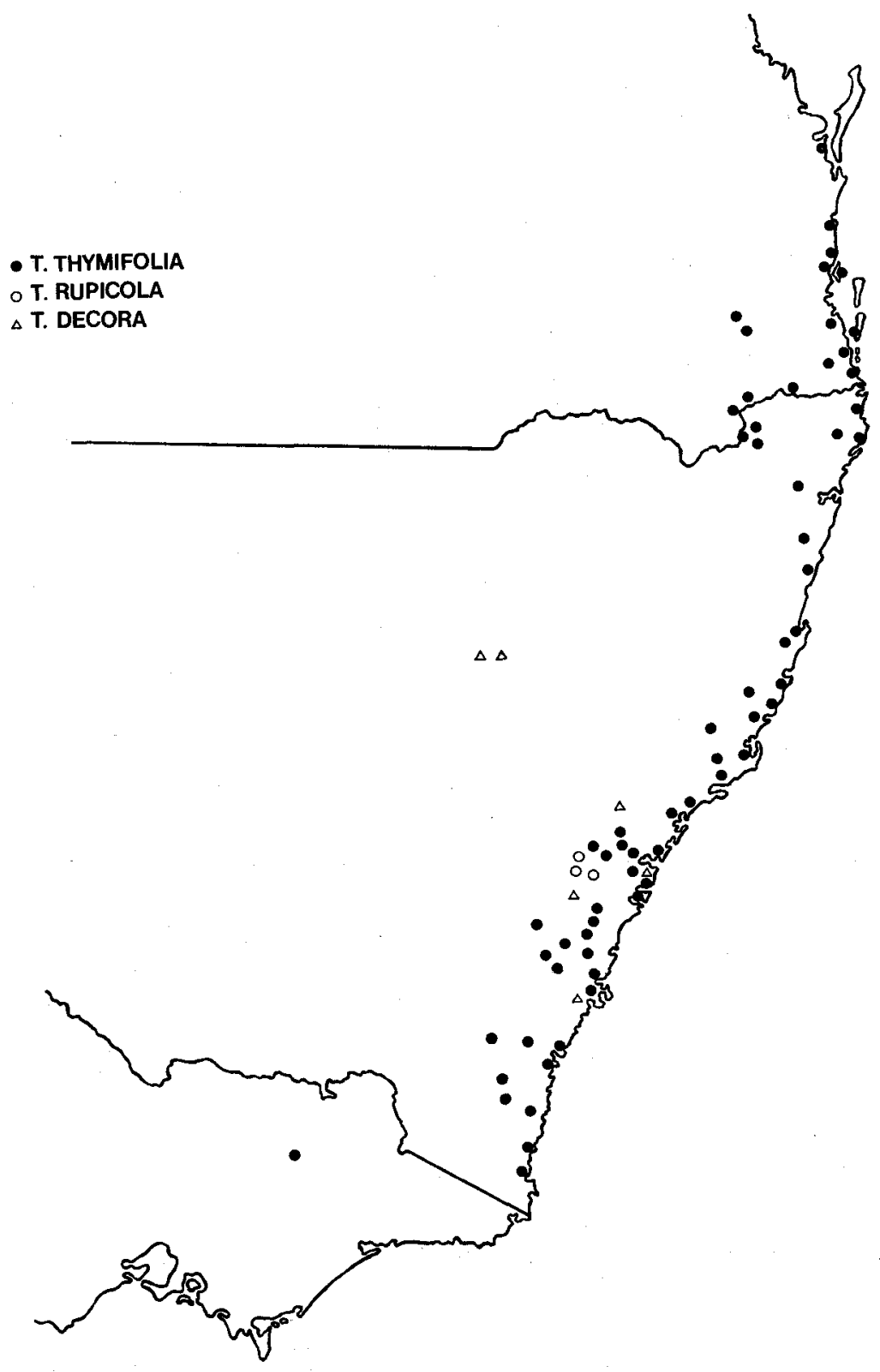


curved, the apex tapering to the anther-tube; anther-tube slightly or conspicuously curved, tapering, $0 \cdot 25-0.5 \mathrm{~mm}$ long with a narrow orifice. Ovary usually with dense, hollow, white, shining hairs $1 \mathrm{~mm}$ or more in length, occasionally with some shorter stiff hairs among them, the shining long hairs may be dense, dense only in patches, few or the ovary completely glabrous, the base of the ovary broad, the apex tapering to a stout style 1-2.25 mm long, broadening below the tip to a base usually covered with erect hairs. Ovules 4, 2 in each loculus, attached in pairs to the upper part of the central axis. Fruit beaked, narrowly ovate to broadly ovate or oblong, 5-7 $\mathrm{mm}$ long and from less than $\frac{1}{2}$ to more than $\frac{1}{2}$ as broad. Seeds $4 \mathrm{~mm}$ long, long-obovoid to cylindrical but flat on the adaxial surface with a scar at the base, dark brown, the hairs sparse to numerous, retrorse to spreading, the appendage cream, with 2-3 coils beyond the seed or with the tip directed along the adaxial surface, with minute spreading hairs.

Distribution: In rocky or sandy heath and sclerophyll forest in the Blue Mountains district of New South Wales. Map 9, see p. 199.

Specimens Examined (Selection Only): New South Wales: Central Coast: Yellow Rock Lookout, Springwood, Cross NSW 119638, 11.1933 (NSW); St Colombas College Estate, North Springwood, O'Flynn NSW 119637, 10.1938 (NSW); Woodford, Cheel NSW 119610, 119611, 6.1913 (NSW); 7 miles [11 km] SW. of Glenbrook, Briggs NSW 119630, 10.1968 (NSW). Central Tablelands: Eastern Sawmill, Waterfall Creek, Mt Wilson, Johnson NSW 119641, 9.1949 (NSW); Mt Wilson, Fletcher NSW 119639, c. 1886 (NSW); Mt Wilson, Maiden NSW 119640, 11.1879 (NSW); $3 \frac{1}{2}$ miles [6 km] along Mt Wilson road from Bells Line of Road, Tindale NSW 119629, 11.1969 (NSW); ridge to Mt Haystack c. $3 \mathrm{~km} \mathrm{~W}$. of Mt Tomah, Pickard 1227, 10.1970 (NSW); between Blackheath and Mt Victoria, Maiden NSW 119606, 10.1886 (NSW); Govetts Leap, Blackheath, Burgess CBG 035659, 11.1970 (NSW); Blackheath, Tindale NSW 119626, 119628, 11.1969 (NSW); Adelina Falls, Lawson, Coxsell \& Coveny 3787, 11.1971 (NSW); Lawson, Camfield NSW 119634, 119607, 10.1896(NSW); Hazelbrook, Michael 1922, 12.1929 (NSW); Wentworth Falls, Bowden \& Coveny 3372, 11.1970 (NSW 114384); Wentworth Falls, Tenison-Woods 12.1882 (MEL); Wentworth Falls, Blakely NSW 119603, 119616, 119621-119623, 119625, 11.1938 (NSW); Wentworth Falls, Lawson 10.1924 (CANB 5603); near Sublime Point, Leura, Goode 527, 12.1961 (NSW); Orphan Rock, Katoomba, Blakely NSW 119631, 10.1937 (NSW); Katoomba, Camfield NSW 119615, 12.1908 (NSW); Kings Tableland, Perrin NSW 119618, 10.1969 (NSW); Kings Tableland, Burgess 10.1962 (CBG 12677); Burragorang to Wentworth Falls, Maiden NSW 119642, 119624, 10.1898 (NSW); Mt Solitary, 5 miles [8 km] S. of Katoomba, Constable NSW 52731, 11.1960 (NSW).

Specimens labelled Flat Rock, Middle Harbour, Helms 10·1900 (NSW 119605) and North Shore, Sydney, Woolls (MEL 1007772 at least in part) belong to this species but may have had their labels confused.

This species has been included in $T$. ericifolia $\mathrm{Sm}$. by most authors.

$T$. rupicola is probably quite closely related to $T$. thymifolia from which it differs in its linear and closely revolute leaves. It is superficially similar to $T$. ericifolia, $T$. neglecta and $T$. rubioides but can be readily distinguished by its fine white stemhairs. Occasionally the two latter species can bear similar hairs but they have at least some minute erect or retrorse hairs as well. An examination of the ovulenumber will always serve to distinguish them.

33. Tetratheca thymifolia Sm., Exot. Bot. 1: 41, t. 22 (1805); J. E. Smith in Rees Cycl. 35 (2): (1817); Steudel, Nomencl. Bot.: 828 (1821); Candolle, Prodr. 1: 343 (1824); Sprengel, Syst. Veg. 2: 214 (1825); Steudel, Nomencl. Bot. [ed. 2] 2: 673 (1841); A. Gray in Hooker's J. Bot. Kew Gard. Misc. 4: 200 (1852); Steetz, Familie Tremandreen: 11 (1853); Schuchardt, Syn. Tremandr.: 30 (1853); Bentham, Fl. Austral. 1: 130 (1863); Woolls, Pl. Indig. Neighb. Sydney: 11 (1880); F. M. Bailey, Syn. Queensland Fl.: 21 (1883); C. Moore, Census Pl. New South Wales: 5 (1884); F. M. Bailey, Queensiand Fl.: 76 (1899); Farmar in Bot. Mag.: t. 8028 (1905); Cheel in Proc. Linn. Soc. New South Wales 38: 527 (1913) where other references are included; Domin in Biblioth. Bot. $22\left(89^{4}\right)$ : 854 (1927); Beadle, Evans \& Carolin, Handb. Vasc. Pl. Sydney Distr.: 148 (1963); Beadle, Evans \& Carolin, Fl. Sydney Region: 172 (1972); Beadle, Stud. Fl. NE. New South Wales: 156 (1973). 
TYPE: I have not seen Smith's specimen but from his illustration and good description, there can be no doubt of its identity. Bentham has cited and therefore seen this specimen. N. T. Burbidge matched CANB 15926 and CANB 5634 against it at Kew, 8.10.1954.

Synonymy: Tetratheca thymifolia var. angustifolia Schuchardt, Syn. Tremandr.: 31 (1853). TYPE: In Herb. Reg. Berol. Willden. et Lehm. Sieber solum legit. I have not attempted to trace these specimens.

Tetratheca thymifolia forma latifolia Domin in Biblioth. Bot. $22\left(89^{4}\right): 854$ (1927). HoLoTYPE: Glasshouse Mountains [Queensland], C. T. White 9.1909 in herb. Domin. I have not seen this specimen but BRI 013076 is probably a duplicate.

Tetratheca thymifolia var. latifolia Schuchardt, Syn. Tremandr.: 31 (1853) nomen nudum.

Tetratheca thymifolia var. hebecarpum Steetz ex Schuchardt, Syn. Tremandr.: 31 (1853) nomen nudum, in synon.

Tetratheca thymifolia var. leiocarpum Steetz ex Schuchardt, loc. cit. nomen nudum, in synon.

Tetratheca ericifolia var. thymifolia $(\mathbf{S m}$.) Maiden et Betche, Census New South Wales Pl.: 119 (1916) incorrectly citing Mueller as the author. F. Mueller, PI. Indig. Colony Victoria 1: 183 (1860-1862), implies the status but does not make the combination. TYPE: As for Tetratheca thymifolia.

An erect or more frequently straggling shrub usually $0 \cdot 2-1 \mathrm{~m}$ in height with many, usually erect, stems rising in clusters from a woody rhizomatous stock and usually with lateral spreading branches in the upper part of the plant. Stems terete, often covered with irregular vertical ridges, with dense, white to fawn, tubercle-based spreading, somewhat twisted or even curled setae to $1.5 \mathrm{~mm}$ in length, or with more sparse and straight antrorse setae, rarely glabrous, the stems $0.6-1.5 \mathrm{~mm}$ broad in the flowering region, the branching alternate, opposite or with several branches arising together, usually erect, occasionally spreading. Leaves usually in whorls of 3-5, rarely a few opposite, alternate or in whorls of $6,(2-) 5-15(-20) \mathrm{mm}$ long and $1-8 \mathrm{~mm}$ wide, very broadly to very narrowly elliptical, rarely almost linear or almost orbicular, the upper surface with scattered, shining, usually antrorse, tubercle-based, white setae or hairs, often $1 \mathrm{~mm}$ long especially on the margins, occasionally short, straight or tending to be undulate, the lower surface paler, with scattered shining hairs, dense on the midrib, the margins loosely revolute, recurved or rarely flat, the apex obtuse or acute, often with a short, blunt, incurved point, the petiole, c. $1 \mathrm{~mm}$ long; in some coastal specimens the leaves may be quite glabrous and rather turgid, usually narrower and often more acute, while in areas of higher altitude the leaves may be very densely hairy. Flowers occurring singly, rarely 2 together, in the upper leafaxils, the bracts variable, often 2 or even $3 \mathrm{~mm}$ long, usually brown, lanceolateacuminate and with a few or many long hairs. Peduncles lengthening as the flower matures, in mature flowers 5-23 mm long, rarely glabrous, usually with sparse or numerous shining white hairs, of variable length but the longest rarely $1 \mathrm{~mm}$, the hairs erect or somewhat retrorse, straight or somewhat curved or twisted, the top of the peduncle enlarging, usually gradually and then abruptly to form a receptacle c. $1 \mathrm{~mm}$ in diameter. Calyx-segments 4 , deciduous, usually dark-coloured, $(1 \cdot 5-) 2 \cdot 5-3(-5)$ $\mathrm{mm}$ long, lanceolate to broadly ovate, acuminate to long-acuminate, rarely acute, with shining, fine, white, straight or curled hairs from less than 0.5 to $1 \mathrm{~mm}$ in length, and often with red glandular-tipped setae c. $0.5 \mathrm{~mm}$ or more in length, rarely glabrous or without fine white hairs, the inner surface with short curled hairs near the margin and apex, rarely glabrous, each segment attached inside the top of the receptacle and usually a little thickened across the base. Petals 4 , dark pink or not infrequently white, variable in shape, usually broadly ovate or linguiform, rarely elliptical, 6-15 $\mathrm{mm}$ long and more or less than $\frac{1}{2}$ as wide with the greatest width from near the centre to the top $\frac{1}{3}$, deciduous. Stamens usually $8,3-4 \mathrm{~mm}$ long, the filament $0.5-1 \mathrm{~mm}$ long, the body of the anther $2-3 \mathrm{~mm}$ long, the lower c. $0.5 \mathrm{~mm}$ sometimes more or less flattened, the body above this curved to a variable extent, glabrous, rarely with a few hairs, tapering at the top to the anther-tube; anther-tube curved, $0.75 \mathrm{~mm}$ or less in length, contracting to a narrow, occasionally broad, orifice (fig. 4). Ovary with dense, short, antrorse hairs, and hollow shining hairs up to $1 \mathrm{~mm}$ long, often with long, slender, glandular-tipped hairs as well, rarely quite glabrous, the base of 
the ovary broad, the apex rounded or tapering to a slender or rather stout style $1 \cdot 5-2.5 \mathrm{~mm}$ long and usually with dense, short, stiff hairs at the base. Ovules 4, 2 in each toculus, attached to the upper part of the central axis (fig. 5). Fruit cordate to obcordate, depressed-globular or cuneate, beaked, often irregularly developed, 4-6 mm long and as wide or somewhat less in width, the axis a little thickened at the placenta. Seeds $2 \cdot 5-3 \mathrm{~mm}$ long, in general ovoid and very turgid, flat or concave on the adaxial surface with a scar above the base, shining, red-to dark-brown, with few or many spreading hairs, the appendage pale cream with up to 3 coils, sometimes curved along the adaxial side and back, with long fine hairs.

Distribution: Usually, but not invariably, in sandy soils in heath and sclerophyll forest, in coastal and adjacent tableland areas from S. Queensland to N. Victoria. Map 9, see p. 199.

Specimens Examined (Selection Only): Queensland: Wide Bay District: Tuan, Hyland 5.1957 (BRI): near Noosa, Phillips 8.1963 (CBG 021501). Moreton District: Woombye, 5.1911 (BRI); Caloundra, Everist 417, 8.1933 (BRI); sandy scrub around Beroa, Leichhardt 9.1843 (MEL, NSW 125419, 125418); Glasshouse Mtns, White 9.1909 (BRI 013076); Bribie Island, Eaves 1872 (MEL); Crows Nest, Brass (CANB 23820); Sunnybank, Hubbard 3458, 7.1930 (BRI); Canungra, White 7803, 8.1931 (BRI). Darling Downs: 1 mile [1.6 km] S. of Dalveen on Stanthorpe Road, Everist \& Webb 1298, 11.1946 (BRI, CANB); Stanthorpe, Jones 10.1964 (CANB 145643).

New South Wales: North Coast: Mt Lindesay, Boorman NSW 125388, 8.1916 (NSW); Pottsville, Phillips 8.1963 (CBG 021229, AD); Ballina, Watts NSW 125383, 9.1900 (NSW); Girard State Forest, 30 miles [48 km] from Tenterfield on Casino road, Hassey NSW 19697, 11.1932 (NSW); Coffs Harbour, White 7419, 10.1930 (BRI); Port Macquarie, Brown NSW $125393,2.1897$ (NSW); Comboyne, Chisholm NSW 125404, 6.1934 (NSW); Taree, Burgess 3.1962 (CBG 006830); Alum Mtn, Bulladelah, Maiden NSW 125396, 10.1907 (NSW); Myall Lakes, Broadwater, Earp 6428, 1.1964 (NSW); Nelsons Bay, Port Stephens, Clarke 9.1915 (CANB 5604); Newcastle, Leichhardt NSW 125409, 9. ?.1842 (NSW); Awaba, Boorman NSW 125415, 10.1899 (NSW). Central Coast: Grassy Hill, S. of Putty, Constable NSW 19692, 9.1948 (NSW); S. of Mountain Lagoon, Thompson 2142, 9.1974 (NSW); Mountain Lagoon road via Bilpin, Burgess 7.1969 (CBG 031162); Gosford, Deane NSW 125335, 1888 (NSW); Maroota, Blakely NSW 125351, 9.1938 (NSW); Hornsby, Blakely NSW 125352, 125340, 10.1914 (NSW, BRI); Oxford Falls, Chippendale NSW 125353, 8.1953 (NSW); Manly Beach, Woolls (MEL 1008138); Waverley, Camfield NSW 125323, 11.1898 (NSW); Burragorang, Davis NSW 125322, 12.1923 (NSW); Budgong, Shoalhaven R, Rodway NSW 125312, 9.1921 (NSW). South Coast: Huskisson, Rodway NSW 125359, 10.1915 (NSW); near Tomerong, Phillips 3.1961 (CBG 024967): Beulah Mtn, 26 miles [42 km] SW. of Nowra, Hartley 10.1943 (CANB 15296); Kioloa State Forest, Pullen 4149, 10.1966 (AD, CANB, NSW); near Burrawarra Point, S. of Batemans Bay, Craven 616, 10.1965 (CANB, MEL, NSW); Belowra, Whaite 455, 12.1949 (NSW); Mt Dromedary, Reader 5.1880 (MEL); Merimbula-Pambula, Boorman NSW 125370, 8.1915 (NSW); Twofold Bay, herb. Mueller (AD). Northern Tablelands: Boonoo Boonoo, Stuart (MEL); Timbarra, Stuart (MEL). Central Tablelands: Mt Irvine, Cleland 6.1915 (AD); Mt Wilson, White 8511, 8.1932 (BRI); Mt Tomah, Burgess 9.1960 (CBG 006828); Hat Hill, Blue Mountains, Day 2.1936 (CANB 10322); 1.6 miles $[2.5 \mathrm{~km}] \mathrm{N}$. of Richlands-Wombeyan Caves road on track to Mt Werong, Belcher 928, 12.1967 (MEL); Hill Top, Cleland 10.1913 (AD); Mittagong, Woolls (MEL); Fitzroy Falls, Pullen 3723, 11.1962 (CANB); Wingello, Boorman $N S W$ 125445, 12.1913 (NSW). Southern Tablelands: Near Marulan, Gauba 10.1951 (CBG 002936); Barbers Creek, Maiden NSW 125448, 1.1898 (NSW); Endrick R, Whaite 2928, 10.1965 (NSW); Currockbilly Mtn, Constable 7445, 9.1967 (NSW); Clyde Mtn, Evans 9.1926 (CANB 5634); Parkers Gap, Gourock Range, E. of Captains Flat, Briggs 4365, 10.1971 (NSW); Bendethera Caves, 20 miles [32 km] c. W. of Moruya, Constable 6858A, 5.1966 (NSW).

Victoria: Eastern Highlands: Mt Buffalo, Cambage 3743, 1.1913 (NSW); East Gippsland, Walter NSW 125427 (NSW).

The variation within this species would probably merit further study, as several problems are apparent from a study of a wide range of specimens. The forms influenced by salt and shade are often obvious but other variation occurs which seems to have some significance, especially the frequency of occurrence of long-acuminate calyx-segments in the southern highlands and of large-leaved densely hairy plants in the Currockbilly and Mt Wilson areas. The species has some affinity with $T$. rupicola which has a somewhat similar pubescence. The linear, closely revolute and often pungent-pointed leaves serve to distinguish that species. $T$. thymifolia can be distinguished from $T$. bauerifolia by its stem hairs. Varjability in some populations can be attributed to hydridization with $T$. rubioides. 
F. Mueller, P1. Indig. Colony Victoria 1: 182 (1860-1862), and Moore \& Betche, Handb. Fl. New South Wales: 36 (1893), include this species in T. ericifolia and have been followed by other authors-see note under that species.

\section{Tetratheca decora $J$. Thompson sp. nov.}

Holotype: Howes Valley to Putty, $1000 \mathrm{ft}[300 \mathrm{~m}]$, New South Wales, L. A. S. Johnson 20 , 9.1951 (NSW 17675).

Fruticulus $30-40 \mathrm{~cm}$ altus. Ramis setis antrorsis vestiti. Folia alterna, 3-15 mm longa, linearia ad subelliptica. Pedunculi plerumque 3-6 $\mathrm{mm}$ longi; receptaculo c. $1 \mathrm{~mm}$ diametro. Flores 4-meri, Stamina filamentis $1 \cdot 25-2.5 \mathrm{~mm}$ longis; tubis antherarum latis, 1-1.5 mm longis. Ovarium dense pilosum usque glabrum: ovulis 2.

A shrub $30-40 \mathrm{~cm}$ in height with erect or ascending branches from a stout stock. Stems terete but vertically ridged with numerous regularly antrorse white tuberclebased setae usually c. $0.75 \mathrm{~mm}$ in length, the stems $0.6-1.5 \mathrm{~mm}$ broad in the flowering region, the branching erect. Leaves alternate, rarely a few appearing opposite, (3-) 5-10 (-15) $\mathrm{mm}$ long long and usually 1-1.5 mm wide, linear to somewhat elliptical, the upper surface with scattered, stout, tubercle-based antrorse hairs or setae, often only near the margins or absent but then usually replaced by tubercles, the lower surface paler, glabrous or with stout hairs or setae on the midrib, the margins revolute though somewhat variably so, the apex rather straight, blunt or shortly pointed, the petiole short or absent. Flowers occurring singly in the upper leaf-axils, the bracts minute to $2 \mathrm{~mm}$ in length, brown, often dark brown, usually lanceolate to oblanceolate, glabrous or with rather long hairs, some appearing to be attached above the base of the peduncle and to be deciduous, leaving a scar. Peduncles often dark-coloured, usually 3-6 mm long, with few or numerous long, white, shining, antrorse setae to $0.75 \mathrm{~mm}$ in length but often shorter, the peduncles often twisted at the base, gradually expanding towards the top and usually a little more at the extreme top into a receptacle c. $1 \mathrm{~mm}$ in diameter. Calyx-segments 4, deciduous, often dark-coloured, $2 \cdot 5-4 \mathrm{~mm}$ long, broadly ovate to irregularly orbicular, usually acuminate, often long-acuminate, rarely obtuse, crenulate or irregularly toothed in the upper part, glabrous or with a few white hairs or white tubercle-based setae especially near the margins, the inner surface glabrous or with fine hairs over the whole or part i.e. not especially near the margins, the base of each segment not thickened and not set inside the top of the receptacle, in fact the demarcation is often imperceptible. Petals 4, dark pink, somewhat irregularly obovate, $6-15 \mathrm{~mm}$ long and more or less than $\frac{1}{2}$ as wide with the greatest width near or above the centre, deciduous. Stamens usually 8 , occasionally 6 or $10,4-6.75 \mathrm{~mm}$ long; filament $1 \cdot 25-2 \cdot 25 \mathrm{~mm}$ long; body of the anther 2-3 mm long, glabrous or with short stiff hairs, rather abruptly narrowed at the base and contracted at the apex into the anther-tube; anther-tube very broad, 1-1.5 mm long with a broad orifice. Ovary densely hairy with long, white, hollow hairs or with a few hairs or glabrous, the ovary turgid above the axis but flat near the sides which tend to extend between the stamens as the fruit matures, the apex emarginate, the style $3-4 \mathrm{~mm}$ long, narrow and not broadening at the base, glabrous or with short, hollow, white hairs at the base. Ovules 2, 1 in each loculus, each suspended from a projection from the upper part of the axis (fig. 5). Fruit depressed-globular, 4-5 mm long and a little more in width, turgid but flattened, not seen in mature condition. Seeds not seen in mature condition, $4 \mathrm{~mm}$ long, obovoid but flat on the adaxial surface, with the scar only near the base, dark brown, with spreading hairs, the appendage dark cream, twisted along the adaxial side for some distance with 1 or 2 flat coils, with rather long fine spreading hairs.

Distribution: In sandstone heath and sclerophyll scrub in the Warrumbungle Ranges and apparently scattered on the Central and South Coast and in the Blue Mountains of New South Wales. Map 9, see p. 199. 
Specimens Examined: New South Wales: Central Coast: Putty road, 52 miles [84 km] from Singleton, Shoobridge 7.1961 (CBG 002989); Howes Valley to Putty, Johnson NSW 17675, 9.1951 (NSW); bush near Putty, Salasoo 2506, 10.1962 (NSW); Ingleside, near Mona Vale, Williams NSW 131879, 10.1967 (NSW). South Coast: Tomerong road, Rodway NSW 131885, 9.1915 (NSW). Central Tablelands: Mt Dingo, 15 miles [24 km] S. of Katoomba, Mylrea $N S W 131886,10.1953$ (NSW); Mt Mouin, Godfrey NSW 115723, 11.1972 (NSW). North Western Slopes: Warrumbungle Mtns, halfway between Siding Springs Mtn and Belougery Split Rock, Stanley NSW 131883, 10.1966 (NSW); Warrumbungle National Park, Hersey NSW 131884, 10.1958 (NSW); Warrumbungles, E.K.W. NSW 131882, 10.1961 (NSW); Warrumbungle Mtns, McWhirter NSW 131881, 1.1961 (NSW); Coonabarabran, Grieve NSW 131878, 1970 (NSW).

This species is referred to by Beadle, Stud. Fl. North Eastern New South Wales: 157 (1973), as an unnamed species.

This very handsome species has no obvious affinities. Its ovule-number and anther-shape could show a link with $T$. glandulosa but the stem-hairs resemble those of $T$. ericifolia. The ovary is unlike that of any other species.

35. Tetratheca gunnii Hook.f., Fl. Tasmaniae 1: 36 (1855); Chodat in Engler \& Prantl, Pflanzenfam. 3: 321, fig. 174 (1897).

Holotype: Asbestos Hills, North-west Tasmania, Gunn 1944. The specimen Asbestos Hills, Gunn 1944, 26.x.1843 (NSW 119672) would be a duplicate.

An erect shrub to $30 \mathrm{~cm}$ in height with very numerous weak stems arising from a woody, perhaps rhizomatous, stock, some stems with erect branches arising near the base and with some branches, also rather erect, in the upper part. Stems terete or with vertical ridges so as to appear quadrangular, covered with tubercles which are often produced into minute, white, erect hairs and with occasional large tubercles often bearing short, stout, light-brown setae to $0.5 \mathrm{~mm}$ in length or their bases, the stems $0.6-0.8 \mathrm{~mm}$ broad in the flowering region, the branching alternate, opposite or with several branches arising together, erect. Leaves alternate, rarely subopposite, 2-6 $\mathrm{mm}$ long and $0.5-1.5 \mathrm{~mm}$ wide, elliptical to linear, the upper surface mostly glabrous but often with some stiff short hairs and usually with a few or numerous large tubercles, some bearing antrorse setae, near the margin, the under surface rarely seen, then with stiff short hairs, the margins closely revolute mostly over the midrib, in occasional leaves the under surface and midrib visible, the apex usually bearing a blunt point often surrounded by very small stiff hairs, occasionally tipped with a glandular-tipped seta, the petiole distinct, attached to a swollen node. Flowers occurring singly, perhaps occasionally 2 together, in the axils of leaves, usually along a considerable length of the stem, the bracts c. $1 \mathrm{~mm}$ long, dark brown, concave, glabrous or with a few hairs, especially on the upper surface and rarely occurring well above the base of the peduncle. Peduncles lengthening as the flower matures, 2-4.5 $\mathrm{mm}$ long in the mature flower, dark-coloured, glabrous with shining spots, gradually widening from the base and somewhat 4-angled in the upper part, $0.5 \mathrm{~mm}$ in diameter at the top or widening again at the extreme top to almost $1 \mathrm{~mm}$, the peduncles tending to twist at the base. Calyx-segments 4, deciduous, dark-coloured c. $1 \mathrm{~mm}$ long, broadly ovate, acute, glabrous or with a few slender, short, red-tipped glandular hairs especially near the margin, the inner surface with a fringe of fine curled hairs near the margin and at the apex, the segments attached well inside the top of the receptacle but little thickened at the base. Petals 4, said to be usually white, obovate, elliptical or even ovate, $3 \cdot 5-4.5 \mathrm{~mm}$ long and more or less than $\frac{1}{2}$ as wide with the greatest width tending to be above, more rarely below, the centre, deciduous. Stamens usually 8 , c. $2 \mathrm{~mm}$ long; filament $0.5 \mathrm{~mm}$ long; body of the anther $1.5 \mathrm{~mm}$ long, glabrous, the lower part flattened and somewhat curved, the apex much expanded, c. $1.25 \mathrm{~mm}$ broad and terminating in a large pore, i.e. the anther-tube absent (fig. 4). Ovary with glandular hairs and a few short shining hairs; the base broad, the apex rounded, the glabrous, slender style $1.5 \mathrm{~mm}$ long and widening a little at the base. Ovules 2, 1 in each loculus, attached to the top of the central axis. Fruit not seen. 


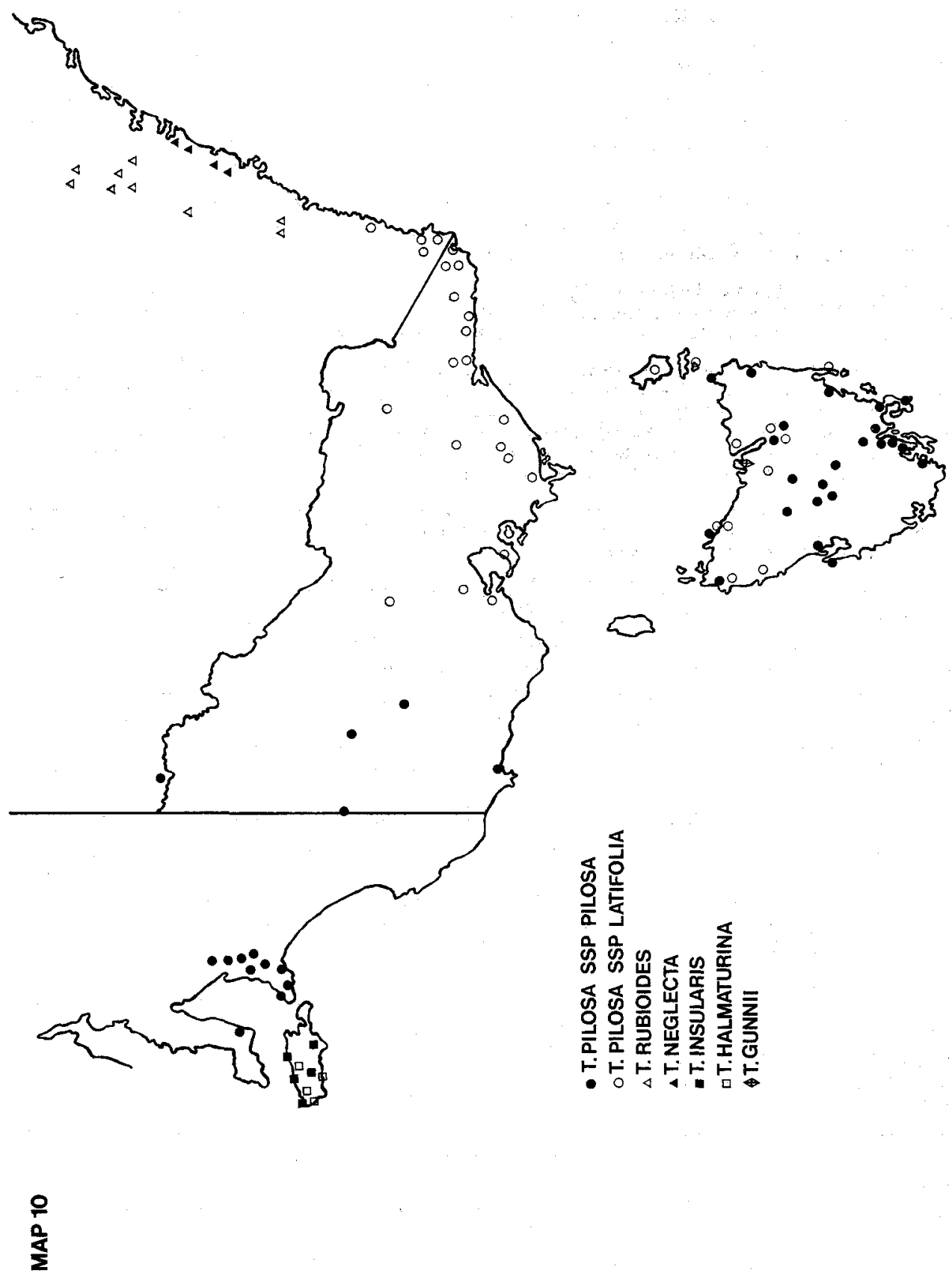

Distribution: On grassy lands and serpentine rock in N. Tasmania: Known only from the Type specimen which was from hills W. of the mouth of the Tamar R. Map 10, above.

Specimens EXamined: TASMANIA: Asbestos Hills, Gunn 1944, 10.1843 (NSW 119572); Archer (NSW 119671). 
This species is included by Bentham, Fl. Austral. 1: 132 (1863), in Tetratheca pilosa var. procumbens, by Rodway, Fl. Tasmania: 10 (1903), in Tetratheca pilosa var. calva and by Curtis, Stud. Fl. Tasmania: 57 (1956), in T. pilosa. I cannot include $T$. gunnii in that species, in spite of resemblances, because it has such distinct anthers and there is such a definite statement by the collector that " $T$. pilosa, which grew along with it, retained a totally different habit and appearance". The genus contains a number of species with very restricted distributions and only further collections and field observation can put the matter beyond doubt.

36. Tetratheca rubioides $A$. Cunn. in Field, Geogr. Mem. New South Wales: 336 (1825) 'rubiaeoides' (the species is based on the name Rubia, the stem of which is "rubi"); Steudel, Nomencl. Bot. [ed. 2] 2: 673 (1841).

HolotyPE: Rocky declivities, Blue Mountains, New South Wales, A. Cunningham 44, Oct. $1822(\mathrm{~K})$. I have seen a photograph of the Holotype. Miss Helen Aston has examined the Type specimen and found it a good match for NSW 125242.

SYNonYmy: Tetratheca richardsiana Blakely in Austral. Nat. 10: 247 (1940); Beadle, Evans \& Carolin, Handb. Vasc. Pl. Sydney Distr.: 147 (1963); Beadle, Evans \& Carolin, Fl. Sydney Region: 172 (1972). LECTOTYPE (here chosen): Near Upper Dam, Lithgow Water Supply, Clarence [New South Wales], Blakely, J. and W. J. Buckingham, 21.x.1939 (NSW 125241). I have selected this specimen because it is the only one in which the information on the label is exactly in agreement with that of a specimen cited.

Tetratheca ericifolia var. rubioides (A. Cunn.) Benth., Fl. Austral. 1: 131 (1863) 'rubiaeoides'; Ewart, Fl. Victoria: 713 (1931). HoLOTYPE: As for T. rubioides. These authors were probably basing their concept on $T$. bauerifolia.

A compact shrub usually $30-60 \mathrm{~cm}$ in height with a stout, often branched, stock and usually with erect stems, often branching several times near the base and also branching above, the stock often horizontal and rhizomatous. Stems terete, quadrangular or distinctly ridged with short, white shining retrorse hairs and occasionally also with long, white or fawn, tubercle-based antrorse setae to $1 \mathrm{~mm}$ in length below the nodes (fig. 1), more frequent on younger growth, the stems $0.6-$ $1.0 \mathrm{~mm}$ broad in the flowering region, the branching alternate, opposite or with several branches arising together, erect. Leaves usually in whorls of 5-7, rarely less on the lower parts of the branches, (3-) 5-10 (-15) mm long and less than $1 \mathrm{~mm}$ broad, c. $1 \mathrm{~mm}$ in specimens from the Southern Tablelands, linear, the upper surface densely covered with very short white erect or slightly antrorse hairs, the lower surface seldom seen, the margins very closely revolute, often hiding the midrib, the apex rounded with a short blunt point, the petiole absent. Flowers occurring singly in the upper leaf-axils, the bracts minute to $1 \mathrm{~mm}$ in length, mid- to darkbrown, usually lanceolate, concave and with a few hairs. Peduncles 4-9 (-12) mm long, dark-coloured, often with some shining spots, glabrous or, less frequently, with short, erect, white hairs, somewhat variable in the expansion of the upper part but usually abruptly expanded at the extreme top to form a receptacle $0.5-1 \mathrm{~mm}$ in diameter. Calyx-segments 4 , deciduous, from less than 1.5 to $2 \mathrm{~mm}$ in length, usually dark-coloured and with occasional shining spots, very broadly ovate to broad-lanceolate, obtuse, acute or acuminate, glabrous or very rarely with a few fine white hairs or occasional glandular hairs near the margin, the inner surface with some curled hairs inside the margin, the lower part of each segment attached well inside the top of the receptacle but not or very little thickened above the rim of the receptacle. Petals 4, dark pink (the specimen from Bare Rock (NSW 125235) appears pale pink), obovate to broadly obovate or linguiform, often rather strapshaped, i.e. straight-sided, 5-11 mm long and from as wide to $\frac{1}{3}$ as wide with the greatest width usually near or above the centre, deciduous. Stamens $8,2 \cdot 25-3 \mathrm{~mm}$ long, $3.5 \mathrm{~mm}$ in Southern Tablelands specimens; filament $0.5 \mathrm{~mm}$ or less in length; body of the anther $1.5-1.75 \mathrm{~mm}$ long. glabrous, the base flattened, rather abruptly, for the lower $0.25 \mathrm{~mm}$ and curved or angled, often strongly, the upper part contracting into the anther-tube; anther-tube tapering, curved, $0.5 \mathrm{~mm}$ or less in length with a narrow orifice. Ovary with numerous, minute, erect hairs or glabrous, the base broad, the apex rounded or tapering into a slender style $1.5 \mathrm{~mm}$ long, $2.5 \mathrm{~mm}$ in the 
Clyde R specimen (NSW 119648), and usually widening and with minute hairs at the base. Ovules 2, 1 in each loculus, attached near the top of the axis. Fruit obovate or cuneate, somewhat beaked or acute, $5 \mathrm{~mm}$ long and $\frac{1}{2}$ as wide. Seeds c. $3 \mathrm{~mm}$ long, shortly cylindrical, oblique at the base with a scar at one side, the hairs spreading and retrorse, the appendage cream with 3 or 4 coils beyond the seed and with a few short hairs.

DistRIBUTION: In heath and dry sclerophyll forest, mainly on sandstone, in the northeastern part of the Central Tablelands and adjoining coastal areas and in the north-eastern part of the Southern Tablelands of New South Wales. Map 10, see p. 205.

Specimens Examined: New South Wales: Central Coast: S. of Mountain Lagoon, Thompson 2143, 9.1974 (NSW); 3.7 road miles [6 km] NE. of Bilpin on Mountain Lagoon road, Campbell \& Pickard 1224, 10.1970 (NSW): Tabarac Ridge, Kurrajong Heights, Salasoo 1499, 12.1965 (NSW). Central Tablelands: Bare Rock c. 25 miles [40 km] directly E. of Rylstone, McGillivray 1595, 2.1966 (NSW 125235); Kekeelbon Mtns, Whaite 3276, 9.1969 (NSW); Wolgan Gap, Briggs NSW 125237, 11.1960 (NSW); Mt Cameron track c. 14 miles [22.5 km] N. of Bell, Black \& Pickard 726, 11.1969 (NSW); Clarence to Wolgan, Maiden NSW 125238, 10.1906 (NSW); Du Faurs Rocks, Mt Wilson, Coveny NSW 125240, 7.1966 (NSW); near Newnes Junction, Blakely \& Buckingham NSW 125244, 11.1938 (NSW); near Clay Pits, Clarence, Blakely, Buckingham \& Buckingham NSW 2209, 125229, 11.1938 (NSW); near Clay Pits, Clarence, Blakely, Buckingham \& Buckingham NSW 125233, 10.1939 (NSW); near Upper Dam, Lithgow Water Supply, Clarence, Blakely, Buckingham \& Buckingham NSW 125241, 10.1939 (NSW); $\frac{1}{4}$ mile $[0.4 \mathrm{~km}] \mathrm{W}$. of Clarence tunnel, Blakely \& Buckingham NSW 125239, 11.1938 (NSW); Wolgan-Clarence road, $\frac{1}{4}$ mile $[0.4 \mathrm{~km}]$ from the old platform, Blakely NSW 125242, 11.1938 (NSW); Clarence, Blakely NSW 125230, 11.1938 (NSW); Clarence, Blakely \& Buckingham NSW 125232, 11.1938 (NSW); Blackheath, Constable NSW 3728, 11.1946 (NSW); Blackheath, Althofer NSW 125234, 3.1947 (NSW); Blackheath, Althofer 12.1946 (MEL); Blue Mountains, Atkinson (MEL); Colong to Mt Werong, Cambage 12.1911 (SYD, NSW 116466). Southern Tablelands: Head of Clyde R, c. 15 miles [24 km] S. of Nerriga, Rodway NSW 119648 , 10.1937 (NSW); Braidwood district, 3,200' [975 m], Bäuerlen 113, 11.1886 (MEL).

This species is one of a group related to $T$. pilosa. In $T$. rubioides there are few of the long stem-hairs characteristic of $T$. pilosa but many of the short stiff hairs. These however are for the most part retrorse. Its closest relative is $T$. neglecta from which it differs especially in the numerous retrorse stem hairs. The Southern Tableland specimens are somewhat different in aspect but are probably best placed here as they agree in all essentials with those from the Blue Mountains. Variability in some populations of $T$. rubioides can be attrituted to hybridization with $T$. thymifolia.

\section{Tetratheca neglecta $J$. Thompson sp. nov.}

HolotyPe: Como [New South Wales], Julius H. Camfield 26.ix.1898 (NSW 119664).

Fruticulus $15-60 \mathrm{~cm}$ altus. Rami pilis minutis erectis et pilis setiformibus vestiti. Folia verticillata verticillis 4-6-foliatis, $3-15 \mathrm{~mm}$ longa, linearia. Pedunculi 6-15 mm longi; receptaculo c. $1 \mathrm{~mm}$ diametro. Flores 4-meri. Stamina filamentis c. $0.5 \mathrm{~mm}$ longis; tubis antherarum attenuatis, $0.25-0.75 \mathrm{~mm}$ longis. Ovarium plerumque minute pubescens; ovulis 2 .

A compact or occasionally diffuse shrub usually $15-60 \mathrm{~cm}$ in height with a stout, often branched, stock and stems branching several times near the base and often branching again in the upper part, the stock appearing rhizomatous. Stems terete, quadrangular or distinctly ridged with two kinds of hairs, one short, usually minute, white, erect, and if not elsewhere at least above the nodes, the other tubercle-based, seta-like, usually $0.5-1 \mathrm{~mm}$ in length, white to brownish, usually directed antrorsely and outwards but sometimes rather twisted and irregular and if not elsewhere at least below the nodes, the stems $0.7-1.7 \mathrm{~mm}$ broad in the flowering region, the branching alternate, opposite or with several branches arising together, erect. Leaves in whorls of 4-6, rarely less at the base of the stem, (3-) 5-10 (-15) mm long and less than $1 \mathrm{~mm}$ broad, but more than $1 \mathrm{~mm}$ in the Byrnes Gap specimen (NSW 114063), linear, often recurved, the upper surface with sparse or numerous tubercles towards the sides, often bearing antrorse fawn to brown setae, frequently also with minute 
erect or slightly antrorsely inclined hairs, the lower surface, where seen, glabrous, except for occasional setae on the midrib, and short stiff hairs in NSW 114063, the margins closely revolute often covering the midrib, the apex blunt or pointed but not pungent, the point occasionally recurved or incurved, the petiole absent. Flowers occurring singly in the upper leaf-axils, the bracts minute up to $1 \mathrm{~mm}$ in length, lanceolate-concave, pale to dark-brown and with a few hairs. Peduncles 6-12 $(-15)$ $\mathrm{mm}$ long, dark-coloured, often with some shining spots, glabrous except in the West Dapto specimen (NSW 119646) which has scattered, shining, short, white hairs the longest of which tend to be antrorse, the upper part of the peduncle usually thickened and tending to curve, expanding further at the top to form a receptacle $1 \mathrm{~mm}$ or more in diameter, less than $1 \mathrm{~mm}$ in NSW 114063 and the Carrington Falls specimen (NSW 115057) which also has longer peduncles than most specimens. Calyx-segments 4, deciduous, $1 \cdot 5-2 \mathrm{~mm}$ long, usually dark-coloured with occasional shining spots, from almost orbicular to ovate but usually broadly ovate, acute or acuminate, usually glabrous, rarely with occasional white hairs, the inner surface with some curled hairs inside the margin, the lower part of each segment attached well inside the edge of the receptacle and with a ridge across the back above the rim of the receptacle. Petals 4, dark pink, rarely white, obovate, rarely elliptical, to broadly obovate or linguiform, (5-) 7-10 $\mathrm{mm}$ long and more or less than $\frac{1}{2}$ as wide with the greatest width usually well above the centre, deciduous. Stamens usually $8,2 \cdot 75-3 \mathrm{~mm}$ long; filament c. $0.5 \mathrm{~mm}$ long; body of the anther $2 \mathrm{~mm}$ long, glabrous, the base flattened for the lower $0.5 \mathrm{~mm}$, above this slightly or strongly curved or angled, the top tapering into the anther-tube; anther-tube curved, tapering, $0.25-0.75 \mathrm{~mm}$ long with a narrow orifice. Ovary with numerous, minute, erect hairs, rarely glabrous, the top rounded or tapering into a slender style $1.5-2 \mathrm{~mm}$ long and broadening towards the base with the lower part covered with minute erect hairs, the ovary turgid on a broad base. Ovules 2, 1 in each loculus, attached to the upper part of the central axis. Fruit broadly elliptical to almost oblong, broader near the top, somewhat beaked, $6 \mathrm{~mm}$ long and $\frac{1}{2}$ as wide, the axis not noticeably thickened. Seeds not seen.

Distribution: In sandy heath and dry sclerophyll forest in the southern part of the Central Coast of New South Wales. Map 10, see p. 205.

Specimens Examined: New South Wales: Central Coast: Port Jackson district, Camfield NSW 119647, 10.1895 (NSW); Port Jackson, Camfield NSW 119656, 1897 (NSW); ArncliffeCanterbury, Fletcher NSW 119665 10.1886 (NSW); Kogarah, Camfield NSW 119654, 11.1899 (NSW); Oatley, Camfield NSW 119660, 11.1892 (NSW); Como, Camfield NSW 119664, 9.1898 (NSW); Como, Camfield NSW 119655, 11.1896 (NSW); Como, Fletcher NSW 119653, 3.1887 (NSW); Bottle and Glass Head, $1 \mathrm{~km}$ W. of Como, Johnson \& Briggs NSW 114408, 11.1970 (NSW); Menai, Coveny NSW 119666, 9.1966 (NSW); Gymea, Goode 448, 10.1961 (NSW); Sutherland, Camfield NSW 119622, 8.1893 (NSW); near Sutherland, St John 24547, 12.1950 (NSW); National Park near road from Audley to Wattamolla, Goode 428, 10.1961 (NSW); National Park, Sydney, Morrison 10.1896 (AD); National Park, Blakely NSW 119652, 11.1938 (NSW); Uloola Track, Royal National Park, between Waterfall and Heathcote, Coveny 2113, 9.1969 '(NSW); Heathcote, Fletcher NSW 119657, 9.1888 (NSW); Heathcote, Meebold 11239, 5.1933 (AD); Garwarra Reserve, Jacobs NSW 119668, 10.1937 (NSW); Helensburgh, Cross NSW 119663, 8.1945 (NSW); Byrnes Gap, N. of Yerranderie, Mitchell' NSW 114063, 9.1969 (NSW); West Dapto, Cambage NSW 119646, 5.1901 (NSW); Carrington Falls, 4 miles [6 km] SE. of Robertson, Coveny 922, 11.1969 (NSW 115057).

This species has been included in Tetratheca ericifolia in collections. This, no doubt, is due to its superficial resemblance to $T$. rupicola which has always been confused with that species.

$T$. neglecta is related to $T$. pilosa and bears its characteristic pattern of long and short stem hairs. It is very similar to $T$. rubioides but the latter has a preponderance of very short, stiff, retrorse hairs. Further collections from intermediate localities could connect $T$. neglecta and $T$. rubioides but at present there are no specimens that cannot be placed.

\section{Tetratheca insularis $J$. Thompson sp. nov.} 119673).

HolotyPE: Snug Cove, Kangaroo Island, South Australia, Dr R. S. Rogers 9.1903 (NSW 
Fruticulus usque ad $60 \mathrm{~cm}$ altus plerumque minus quam $20 \mathrm{~cm} . \quad$ Rami et pilis minutis erectis et setiformibus vestiti. Folia alterna vel opposita vel verticillata verticillis 3-5-foliatis, 3-12 mm longa, ovata ad angustissime ovata. Pedunculi 10-20 mm longi; receptaculo usque ad c. $1 \mathrm{~mm}$ diametro. Flores 4-meri. Stamina filamentis $0.5 \mathrm{~mm}$ longis vel brevioribus; tubis antherarum tenuibus curvis, $0.5-1 \mathrm{~mm}$ longis. Ovarium pubescens et pilis glanduliferis parvis dense vestitum; ovulis 2.

Synonymy: Tetratheca ericifolia var. pilosa Tate in Trans. Proc. Roy. Soc. South Australia 12: 62 (1889). HolotyPE: Probably the specimen Ravine de Casoars, Kangaroo Island [South Australia], Tepper 110, 3.1886 (MEL 1007966). Although his name is not mentioned by Tate, Tepper published a list of specimens in Trans. Proc. Roy. Soc. South Australia 10: 290 (1888). These specimens were subsequently submitted for Tate's examination. Tate may have included this name in the erroneous belief that Mueller, in Fragm. 12: 6 (1882), had made a combination at varietal level based on $T$. pilosa Labill. However Mueller did not make the combination in accordance with Art. 32 of the International Code of Botanical Nomenclature (1972).

A small compact shrub to $60 \mathrm{~cm}$ but usually less than $20 \mathrm{~cm}$ in height, with a number of stems branching above but close to a slender branching root stock. Stems stout, terete, somewhat vertically ridged, covered with tubercles, some dense small and white and usually produced into very small white erect hairs and some large and fawn and often bearing long pale-brown setae to $1 \mathrm{~mm}$ in length, usually antrorse, the stems $0.8-1.5 \mathrm{~mm}$ broad in the flowering region, the branches usually spreading, often several arising together. Leaves alternate, opposite or often irregularly into whorls of 3,4 or even 5 , (3-) 4-8 (-12) $\mathrm{mm}$ long, and 1-2 mm wide, ovate to very narrowly ovate, usually but not always recurved to rather loosely revolute, the upper surface covered with short stiff hairs and with large tubercles often bearing antrorse setae especially near the margins, the lower surface paler with short stiff hairs, and occasionally setae, on the midrib, the margins occasionally flat, usually revolute and tending to curl over the midrib towards the apex and expose the under surface near the base, the apex with a short stiff point tending to recurve or incurve, the petiole short but usually distinct. Flowers occurring singly in the axils of upper leaves and often of leaves much lower on the stem, the bracts minute to $1 \mathrm{~mm}$ in length, dark brown, broad-lanceolate-concave with some fine hairs especially on the upper surface. Peduncles lengthening as the flower matures, usually 10-20 mm long in the mature flower, dark-coloured usually with scattered shining spots, glabrous or with a few fine, erect, shining white hairs near the top, slender, the upper part broadening, often curved and expanding abruptly at the top to form a receptacle $1 \mathrm{~mm}$ or less in diameter. Calyx-segments 4, deciduous, dark-coloured with scattered shining spots, 1.5 to more than $2 \mathrm{~mm}$ in length, ovate to broadly ovate, acuminate, glabrous or with a few fine, white, short hairs, the inner surface with fine white hairs especially near the margins and at the tip, the base of each segment attached inside the top of the receptacle but the lower part not thickened above the edge of the receptacle. Petals 4, dark pink, broadly ovate, obovate or abruptly constricted below so as to appear very broadly linguiform, $6-8 \mathrm{~mm}$ long and more or less than $\frac{1}{2}$ as wide with the greatest width just above the centre, deciduous. Stamens usually 8 , c. 3-3.5 $\mathrm{mm}$ in length; filament broad, usually $0.5 \mathrm{~mm}$ or less in length; body of the anther $2-2.5 \mathrm{~mm}$ long, glabrous, the lower $0.5-0.75 \mathrm{~mm}$ flattened and curved, often very strongly, the apex contracted into the anther-tube; anther-tube slender, curved, 0.5-1 $\mathrm{mm}$ long with a narrow orifice. Ovary with dense, short, slender, stiff, erect hairs and small glandular hairs; the apex rounded, the style $1 \cdot 5-2 \cdot 25 \mathrm{~mm}$ long, rather stout below the tip with slender stiff hairs at the base and variably extending towards the tip. Ovules 2, 1 in each loculus, attached to the top of the central axis. Fruit obovate or cuneate, 5-6 mm long and c. $4 \mathrm{~mm}$ wide, turgid, the axis unthickened at the placenta. Seeds c. $3 \mathrm{~mm}$ long, shortly cylindrical, oblique at the base with a scar at one side, the hairs long, fine and spreading, the appendage cream, coiled closely above the seed and with fine short erect hairs.

Distributron: Kangaroo Island, South Australia. I have no information about its habitat. Map 10, see p. 205.

Spectmens Examined (Selection ONLy): South Australia: Kangaroo Island: Stokes Bay, Rogers NSW 119674, 9.1908 (NSW); W. Stokes Bay, Rogers NSW 119650, 9.1908 (NSW); 
Middle R, Ashby 230, 10.1905 (NSW); Middle R to Western R, Rogers NSW 119651, 9.1908 (NSW); Snug Cove, Rogers NSW 119673, 9.1908 (NSW); 11 miles [18 km] E. of Cape Borda, Phillips 8.1964 (CBG 019663, AD); 3 miles [5 km] E. of Cape Borda, Phillips 9.1965 (CBG 023430); c. $3 \mathrm{~km} \mathrm{~N}$. of Ravine des Casaors, Flinders Chase, Wace 8.1965 (AD); Ravine de Casoar, Tepper 110, 3.1886 (MEL 1007966); near West Bay, Wace 8.1965 (AD); opposite "Karralinga", $17 \mathrm{~km} \mathrm{NW}$. of Karatta, Tudor 11.1974 (AD-U, NSW 116272); 6 miles [10 km] NW. of Karatta on road to Western Highway, Phillips 9.1965 (CBG 023165); MacGillivray, c. $25 \mathrm{~km} \mathrm{SW}$. of Kingscote, Black (AD).

This species is referred to as Tetratheca ericifolia by J. M. Black, Fl. South Australia 2: 346 (1924) and 4: 692 (1929).

Although obviously related to $T$. pilosa this species is quite distinct. The long peduncles distinguish it from all other species of that group.

39. Tetratheca pilosa Labill., Nov. Holl. Pl. Spec. 1: 95, t. 122 (Nov. 1805); Steudel, Nomencl. Bot.: 828 (1821) incorrectly synonymizing $T$. ericifolia 'ericaefolia' Sm.; Candolle, Prodr. 1: 343 (1824) incorrectly synonymizing $T$. glandulosa Sm.; Sprengel, Syst. Veg. 2: 214 (1825) incorrectly synonymizing T. glandulosa Sm.; W. J. Hooker in J. Bot. (Hooker) 1: 248 (1834-1836); W. J. Hooker in Compan. Bot. Mag.: 274 (1836); Steudel, Nomencl. Bot. [ed. 2] 2: 673 (1840) including T. glandulosa Sm.; Steetz, Familie Tremandreen: 11 (1853); Schuchardt, Syn. Tremandr. 24 (1853) including $T$. glandulosa Sm., and T. labillardierei ' $T$. glandulosa Labill.' in part; J. D. Hooker, Fl. Tasmaniae 1: 35 (1855); Benth., Fl. Austral. 1: 131 (1863) including T. gunnii Hook. f., and T. glandulosa $\mathrm{Sm}$. as a var.; Spicer, Handb. Pl. Tasmania: 103 (1878) including T. gunnii; F. Muell., Native Pl. Victoria 1: 62 (1879) including other species; Rodway, Fl. Tasmania: 10 (1903) including 'T. ericifolia Sm. (partly)' as a synonym; Ewart et al., Field Nat. Club Census PI. Victoria: 40 (1923); J. M. Black, Fl. South Australia 2: 346 (1926); Ewart, Fl. Victoria: 713 (1931); J. M. Black, Fl. South Australia [ed. 2] 2: 502 (1948); Curtis, Stud. Fl. Tasmania 1: 57 (1956) including T. gunnii; J. H. Willis, Handb. Pl. Victoria 2: 196 (1973).

TYPE: In capite Van-Diemen, Labillardiere. The specimen Nova Hollandia, Labillardière 1434 (MEL 1008362) would be an Isotype.

Synonymy: Tetratheca calva F. Muell. ex Schuchardt, Syn. Tremandr.: 25 (1853) synonymizing T. labillardierei 'glandulosa Labill.' in part. SYNTYPES: The following specimens have been annotated by Schuchardt: Lobethal [South Australia], 7.1848 (MEL 1008370), in montibus ad rivulum Third-kreek [South Australia], 8.1848 (MEL 1008371), Barossa-range [South Australia], Oswald 1848 (MEL 1008373), in montib. circa oppidulum Macclesfield [South Australia], Mueller 28.9.1848 (MEL 1008368), Bugle-range ad fium. Murray [South Australia], Mueller 11.1848 (MEL 1008383) and Tasmaniae (MEL 1008374).

Tetratheca calva var, pulchella F. Muell. ex Schuchardt, Syn. Tremandr.: 27 (1853). TYPE: Schuchardt cites two specimens, "In insul. Van Diemen legerunt Gunn et in montibus altis Tasmanniae cl. Müller in Herb. Sonder." The specimens Van Diemensland, Gunn, herb. Sonder (MEL 1008363), in montibus altis Tasmaniae, Mueller (MEL 1008381) and MEL 1008382, are probably Type material. MEL 1008363 and MEL 1008382 bear the words " $\beta$ pulchella mihi" in Schuchardt's handwriting. MEL 1008381 has " $\delta$ pulchella Ferd. Müll".

Tetratheca calva var. hispidula Schuchardt, Syn. Tremandr.: 27 (1853). TYPE: Schuchardt cites two specimens "In planitie arenosa versus lacum Victoria [New South Wales], 28 April 1848 et in Sandscrubb Sept. 48. leg. Müller in Herb. Sonder". These are probably MEL 1008372 and MEL 1008369 which are labelied " $\delta$ hispidula mihi" in Schuchardt's handwriting.

Tetratheca glandulosa var. glabrata (incorrectly ascribed to Hooker) Schuchardt, Syn. Tremandr.: 26 (1853) in synon.

Tetratheca glandulosa var. pilosa Hook. f., Fl. Tasmaniae 1: 35 (1855) in synon.

Tetratheca procumbens Gunn ex Hook. f., Fl. Tasmaniae 1: 35 (1855). TYPE: Summit of Western Mountains, elev. 3800 feet; also near the sea, on heathy plains, at Circular Head etc, Gunn 217, 309,649. The specimens Circular Head, Gunn 217/1842, 8.xi.1837 (NSW 119678) and Circular Head, Gunn 217 (NSW 119679) would be duplicates of Type material.

Tetratheca pilosa var. procumbens (Gunn ex Hook. f.) Benth., Fl. Austral. 1: 132 (1863) including $T$. gunnii. TYPE: As for $T$. procumbens.

Tetratheca pilosa var. calva Rodway, Fl. Tasmania: 10 (1903) including T. gunnii Hook.f. TYPE: As for T. procumbens and T. gunnii. 
Tetratheca ericifolia var. pilosa (Labill.) Maiden et Betche, Census New South Wales Pl.: 119 (1916) non Tate in Trans. Proc. Roy. Soc. South Australia 12: 62 (1889). The authors incorrectly credit Mueller with the combination. TYPE: As for T. pilosa.

An erect or spreading shrub with branches up to $60 \mathrm{~cm}$ long arising from a woody stock, sometimes, especially at high altitudes, a small procumbent shrub with stems only a few cm long; the stock often stout and branched. Stems terete or with vertical ridges, often appearing quadrangular, covered with tubercles which are often produced into minute erect or even slightly retrorse white hairs and with scattered or numerous tubercle-based light brown setae $0.5-1.5 \mathrm{~mm}$ (fig. 1), and sometimes, on younger growth, short glandular-tipped hairs, the stems $0 \cdot 4-1 \cdot 2 \mathrm{~mm}$ broad in the flowering region, the branching alternate, opposite or with several branches arising together, erect or spreading at first and soon becoming erect. Leaves alternate, opposite or irregularly in whorls of 3 or 4, 2-15 $\mathrm{mm}$ long and 1-5 $\mathrm{mm}$ wide, linear to broadly elliptical, rarely almost orbicular, the upper surface with or without numerous erect hairs and with scattered setae often over $1 \mathrm{~mm}$ long especially near the margins occasionally reduced to their tubercular bases, the lower surface where seen paler, glabrous or with some fine erect hairs and short hairs or setae on the midrib, the margins closely revolute, often over the midrib, or loosely revolute or recurved or flat, the apex blunt or with a short or pungent point, the base rounded or tapering into a variable but usually distinct petiole. Flowers occurring singly or rarely 2 together in the upper axils, the bracts $0.5-2 \mathrm{~mm}$ long, linear to broad-lanceolate, brown, glabrous or with some hairs on the lower surface and pubescent on the upper surface. Peduncles lengthening as the flower matures, dark-coloured, often with shining spots, 4-9 $\mathrm{mm}$ long in the mature flower, glabrous or with coloured slender glandular-tipped hairs or with minute, erect, stiff, white, sparse hairs, rarely with both kinds, widening in the upper part and again at the top to form a receptacle c. $1 \mathrm{~mm}$ in diameter and somewhat 4-angled. Calyx-segments 4, deciduous, dark-coloured but often appearing scarious, with numerous shining spots, 1-2 $(-2 \cdot 5) \mathrm{mm}$ long, glabrous or with few or many short, broad-based, rather slender glandular-tipped hairs especially on the margin or with a few fine, white, short, hairs, the inner surface with fine hairs inside the margin, broadly to narrowly ovate, obtuse, acute or acuminate, the base of each segment attached well inside the top of the receptacle but the lower part not thickened. Petals 4, dark pink, pale pink or white, occasionally differing on one plant, broadly to narrowly obovate, linguiform, ovate or even elliptical, $3-12 \mathrm{~mm}$ long and very variable in width from less than $\frac{1}{3}$ to more than $\frac{2}{3}$ as wide as long, the greatest width usually in the upper part, rarely near the centre, usually near the apex, deciduous. Stamens usually $8,1.5-4.5 \mathrm{~mm}$ long; filament $0.25-0.75 \mathrm{~mm}$ long; body of the anther $1-2.5 \mathrm{~mm}$ long, glabrous or with small hairs, flattened and resembling the filament for the lower $0 \cdot 25-1 \mathrm{~mm}$ but above this strongly curved often to $90^{\circ}$ or more, the broad part of the body $0 \cdot 75-1.5 \mathrm{~mm}$ long, tapering to the anther-tube; anther-tube from less than 0.25 to more than $1 \mathrm{~mm}$ in length with a narrow or broad orifice. Ovary with scattered, short, slender, glandular hairs, short, stiff, shining hairs and long, often to $1 \mathrm{~mm}$, hollow, shining hairs, although those of any kind may be variable in density or absent, or glabrous, the base of the ovary broad, the apex rounded or tapering to a slender style $1-3.25 \mathrm{~mm}$ long, glabrous or with a few short hairs at the base. Ovules 2, 1 in each loculus, suspended from the top of the central axis. Fruit obovate to cuneate or cordate, often beaked, turgid $3-4.5 \mathrm{~mm}$ long and c. $\frac{2}{3}$ as wide, the axis widening a little at the placenta. Seeds $2.5 \mathrm{~mm}$ long, almost oblong, slightly oblique at the base, flat on the adaxial surface with a scar at the base, the hairs appressed to spreading, the appendage pale with a few hairs and with several twists.

Distribution: From coastal to high mountain heath and sclerophyll forest in SE. Australia. Map 10, see p. 205.

The variation within this species requires further study. If the plants from high altitudes are separated as a subspecies some very similar specimens from coastal localities including the Type of the species present a problem. I have divided the species into two subspecies. These appear distinct over most of their range but they 
are very closely related and it would appear that the species has spread northeastward and north-westwards from Tasmania. To the east it has diverged to a rather uniform subspecies but to the west has diverged less though it is much more uniform than in Tasmania.

1. Leaves usually alternate, occasionally some opposite, $2-15 \mathrm{~mm}$ long, linear to very narrowly ovate, usually c. 1 , rarely more than $1.5 \mathrm{~mm}$ broad, the margins usually closely revolute. Ovary glabrous or pubescent but rarely bearing long hollow shining hairs ...... ssp. pilosa

1.* Leaves alternate, opposite or often irregularly in whorls of 3 or $4,(3-) 5-8(-11) \mathrm{mm}$ long, broadly to narrowly elliptical, rarely almost orbicular, (1-) $2-3(-5) \mathrm{mm}$ broad, the margins flat, recurved or loosely revolute especially near the apex. Ovary usually bearing numerous long hollow shining hairs $\ldots \ldots \ldots \ldots \ldots \ldots \ldots \ldots \ldots \ldots \ldots \ldots \ldots \ldots \ldots \ldots \ldots$ ssp. latifolia

\section{Tetratheca pilosa ssp. pilosa}

SYNonYmY: As for the species.

An erect or spreading shrub with branches up to $60 \mathrm{~cm}$ in length, sometimes, especially at high altitudes, a small procumbent shrub with stems only a few $\mathrm{cm}$ long and all parts reduced in size; the stock often stout and branched. Stems terete or with vertical ridges so as to appear quadrangular, covered with tubercles which are often produced into minute erect or even slightly retrorse white hairs and with scattered large tubercles often bearing short, stout, light-brown setae to $0.5 \mathrm{~mm}$ or more in length and sometimes on younger growth shorter glandular-tipped hairs. Leaves usually alternate but occasionally some opposite, 2-15 mm long and usually c. $1 \mathrm{~mm}$ broad, rarely more than $1.5 \mathrm{~mm}$ wide, linear to very narrowly ovate, the upper surface with numerous, minute, erect hairs and scattered tubercles often bearing long setae especially near the margins, the lower surface where seen glabrous or with short hairs on the midrib, the margins usually closely revolute, with or without the midrib showing, the apex blunt or with a short pungent point. Flowers occurring singly or two together in the upper leaf-axils, the bracts 0.5-2 mm long, usually linear-lanceolate, brown, glabrous or with some hairs on the lower surface, pubescent on the upper surface. Peduncles $1-9 \mathrm{~mm}$ long in the mature flower, glabrous or with coloured, slender, glandular-tipped hairs or with minute, erect, stiff, white, sparse hairs or, rarely, with both, widening and 4-angled in the upper part and widening again at the extreme top to form a receptacle $1 \mathrm{~mm}$ or less in diameter, $1 \mathrm{~mm}$ or a little more in most South Australian specimens. Calyxsegments dark-coloured although sometimes appearing somewhat scarious, with numerous shining spots, $1-2 \mathrm{~mm}$ long, rarely $2.5 \mathrm{~mm}$ long in South Australia, glabrous or with few or many short, broad-based rather slender coloured-tipped glandular hairs especially on the margin, rarely with white hairs near the tip, broadly, rarely narrowly, ovate, obtuse, acute or acuminate. Petals dark pink, pale pink or white, the variation more apparent in South Australia where two colours have been reported on different branches of the same plant, broadly to narrowly linguiform, broadly ovate to ovate or even elliptical, 3-12 $\mathrm{mm}$ long and very variable in width from less than $\frac{1}{3}$ to $\frac{2}{3}$ as wide as long, with the greatest width usually in the upper part, rarely near the centre, usually near the apex. Stamens $1.5-4.5 \mathrm{~mm}$ long, the filament $0 \cdot 25-0.75 \mathrm{~mm}$ long, the body of the anther 1-2 $\mathrm{mm}$ long, the lower $0 \cdot 25-1$ $\mathrm{mm}$ flattened and resembling the filament, strongly curved, the broad part $0 \cdot 75-1 \cdot 5$ $\mathrm{mm}$ long and tapering to an anther-tube less than $0.25-1 \mathrm{~mm}$ long with a narrow, occasionally broad, orifice. Ovary with scattered, slender, glandular hairs and usually with short, stiff, shining hairs, rarely a few long shining hairs, the apex rounded or somewhat tapering to a style $1-3 \mathrm{~mm}$ long.

DistRIBUTION: In coastal or high mountain heath or sclerophyll forest in Tasmania, W. Victoria, SW. New South Wales and SE. South Australia. Map 10, see p. 205.

Specimens Exammed (Selection Only): New South Wales: Far Western Plains: Upper Darling, Henry 1884 (MEL); in planitie arenosa versus lacum Victoriam, Mueller 4.1848 (MEL 1008372).

Victoria: Wimmera: W. Wimmera near Bordertown, Ward 1887 (MEL); Wail, near Dimboola, Gray 9.1947 (MEL). Grampians: Grampians (BRI); Mt William, Sullivan 11.1874 (MEL). Western Coastal Plains: Portland, Beauglehole 37881, 9.1971 (MEL, NSW). 
South Australia: Mt Lofty Ranges: Lyndock valley, Mueller 9.1848 (MEL); Sandy Creek, Tepper 62, 10.1888 (MEL, NSW); Barossa Range, Oswald 1848 (MEL 1008373); Mt Crawford Pine Forest, Phillips 11.1962 (CBG 023131, AD); Chain of Ponds, Blake 16820, 8.1946 (BRI, CANB); Millbrook, Cheel NSW I25127, 8.1924 (NSW); Morialta, Hogan 10.1924 (AD); Lobethal, 7.1848 (MEL 1008370); in montibus ad rivulum Third-Kreek, Mueller 8.- (MEL 1008371); Norton Summit, Black 9.1904 (AD); Mt Bonython, Phillips 9.1964 (CBG 020757, 019604, AD); Mt Lofty, Ising 10.1917 (AD); Upper Waterfall Gully, Eichler 18289, 8.1965 (AD); between Crafers and Aldgate, Salasoo 1673,12.1958 (NSW); Stirling East, Eichler 1425I, 10.1957 (AD); Upper Sturt, Ising 9.1913 (AD); Clarendon (BRI); Bugle Range ad flum. Murray, Mueller 11.1848 (MEL 1008383); in montib. circa oppidulum Macclesfield, Mueller 9.1848 (MEL 1008368); Myponga, Black 11.1918 (AD); Hindmarsh Flats, Black 10.1923 (AD). Fleurieu Peninsula: c. 7 miles [11.3 km] E. of Cape Jervis towards Victor Harbour, Everist $5733,8.1958$ (BRI); Tunkalilla, Cooper 10.1944 (AD 96228229, 96228239); 5 miles [8 km] W. of Waitpinga road, near Victor Harbour, Wilson 1496, 8.1960 (AD, NSW); Port Elliott, Hussey 41, 1893 (MEL). Yorke Peninsula: Stansbury (AD). Without precise locality: Sandscrubb, 9.1848 (MEL 1008369).

TASmania: Cape Portland, Baudinet 1884 (MEL 1008144, 1008276); Circular Head, Gunn $217 / 1842,11.1837$ (NSW 119678); 2 miles [3 km] S. of Marrawah towards Arthur R, Phillips 11.1965 (NSW 114399); Georges Bay, Simson (BRI); Punchbowl near Launceston, Rupp NSW 125144, 10.1921 (NSW); Cradle Mtn, Rodway NSW 119677, 12.1915 (NSW); Mt Ironstone, Rodway NSW 114023, 12.1899 (NSW); Lake St Clair National Park, between Lake St Clair, Cynthia Bay and Mt Rufus, Eichler 16592, 1.1960; Victoria Valley, Rodway NSW 119680, 12.1917 (NSW); Strahan, Rodway 1524, 10.1933 (NSW, AD); Macquarie Harbour, Le Grand (MEL); rocky hills near Swanport, Archer 11.1849 (MEL 1007939, 1007942, NSW 119683); Derwent R, Brown (BRI, MEL 1007950, NSW 125139); Glenorchy, Long 497, 8.1931 (CANB); Waterworks road near Hobart, Phillips 11.1960 (CBG 002994); Mt Nelson, Giblin 11.1929 (CANB 5625); Forestier Peninsula approaching Murdunna, Phillips 11.1960 (CBG 003013); Eaglehawk Neck, Lucas NSW 125146, 11.1924 (NSW); between Barnes Bay and Great Bay, North Bruny Island, Phillips 11.1965 (CBG 013971); Port Cygnet, Weymouth 9.1889 (MEL); Southport, Stuart (MEL). Without precise locality: In montibus altis Tasmaniae, Mueller (MEL 1008381); Tasmaniae (MEL 1008374); Nova Hollandia, Labillardière 1434 (MEL 1008362); Van Diemensland, Gunn herb. Sonder (MEL 1008363); MEL 1008382; MEL 1008301.

\section{Tetratheca pilosa ssp. latifolia $J$. Thompson ssp. nov.}

Holotype: Lind National Park, 12 miles [19 km] W. of Cann R, Victoria, E. F. Constable $5396 A$, 1.xi.1964 (NSW).

Folia alterna vel opposita vel verticillata verticillis 3-4-foliatis, 3-11 mm longa, anguste ad late elliptica vel raro suborbicularia, $1-5 \mathrm{~mm}$ lata, ad marginem plana vel laxe revoluta. Ovarium plerumque pilis longis nitidis vestitum.

A compact or spreading shrub $30-50 \mathrm{~cm}$ in height with erect branches arising from a woody stock. Stems terete but with vertical ridges with the bases of setae spreading along them, the stems densely covered with short white stiff hairs and usually with numerous long rather fine fawn to pale brown setae to $1.5 \mathrm{~mm}$ long. Leaves alternate, opposite or often irregularly in whorls of 3 or 4, (3-) 5-8 (-11) mm long and (1-) 2-3 (-5) mm wide, usually broadly to narrowly elliptical but rarely almost orbicular, the tip usually incurved, the upper surface usually sparsely covered with setae often over $1 \mathrm{~mm}$ in length but occasionally the setae reduced to their tubercular bases, rarely on young growth with glandular tips, the bases near the margin giving the leaf a serrate appearance, often with a few short fine hairs near the base, apex and/or margins, the lower surface, paler usually glabrous except for hairs on the midrib but occasionally with some fine erect hairs, the margins flat, recurved or loosely revolute especially near the apex, the apex blunt or with a small point, rarely pungent. Flowers occurring singly or rarely 2 together in the axils of upper leaves, the bracts usually $0 \cdot 5-1 \mathrm{~mm}$ long, brown, broad-lanceolate, concave, with dense fine hairs on the upper surface but few on the lower. Peduncles 4-7 mm long, glabrous or with scattered, straight, fine, shining hairs, a few to $0.5 \mathrm{~mm}$ in length at the top of the peduncle but most much shorter, the upper part of the peduncle usually broadening for some length and straight or somewhat curved, abruptly widening at the top to form a receptacle usually $1 \mathrm{~mm}$ or less in diameter. Calyxsegments brown and shining, often with spots and appearing scarious, usually $1 \mathrm{~mm}$ in length, broadly ovate-acuminate, often broader than long, usually glabrous but often with a few fine white short hairs or occasionally glandular hairs. Petals dark pink, broadly to narrowly ovate, $5-8 \mathrm{~mm}$ long and from more than $\frac{1}{2}$ to less than $\frac{1}{2}$ 
as wide, with the greatest width well above the centre. Stamens $3-3.5 \mathrm{~mm}$ long; filament c. $0.25 \mathrm{~mm}$; body of the anther $2-2.5 \mathrm{~mm}$ long, the lower $0.5-0.75 \mathrm{~mm}$ flattened and resembling the filament, above this the body strongly curved, often to $90^{\circ}$ or more, the broader part of the body usually $1.5 \mathrm{~mm}$ long with some hairs, minutely scabrous or glabrous, the apex contracted into a usually broad curved anther-tube; anther-tube $0.5 \mathrm{~mm}$ long, occasionally shorter, the orifice usually broad. Ovary with scattered, short, slender, glandular hairs and many short to long, hollow, shining hairs often $1 \mathrm{~mm}$ in length, the hairs of one or other or both kinds of variable length and density or absent, the ovary occasionally glabrous, the apex rounded, the style $2 \cdot 25-3 \cdot 25 \mathrm{~mm}$ long.

Distribution: In coastal heath and sclerophyll forest in S. New South Wales, Victoria and N. Tasmania. Map 10, see p. 205.

Specimens Examined (Selection Only): New South Wales: South Coast: Tilba Tilba, Bate 1881 (MEL); Nurira Creek, Reader 8.1880 (MEL); Twofold Bay, Mossman 249 in part (BRI); Green Cape Lighthouse road, Constable NSW 119675, 10.1954 (NSW); Womboyn Ranges, Mueller 9.1860 (MEL); near Womboyn on Nadgee track before Merika R crossing, Phillips 10.1961 (CBG 003003); Narrabarba Hill, Constable NSW 30973, 10.1954 (NSW).

VICTORIA: Eastern Highlands and Gippsland: Bogong, Galbraith 11.1949 (AD); Genoa, Bäuerlen 376, 2.1887 (MEL); Mallacoota National Park, Phillips 10.1961 (CBG 003005); Lind National Park, Constable 5396A, 11.1964 (NSW); Tambo R below Noyong, Howitt 1882 (MEL); Sale, Williamson 663, 8.1899 (MEL); Macallister Ranges, Mueller (MEL); Traralgon South, Galbraith 11.1949 (AD); Foster, Barton 1925 (MEL). Wilsons Promontory: Squeaky BayLeonard Point, Phillips 11.1961 (CBG 002998); Martins Hill, Audas \& St John 11.1908 (MEL). Port Phillip District: Port Phillip (CANB 195978); near You Yangs, Adoobk 1889 (MEL); Geelong, Wilson 1881 (MEL). Western Highlands: Bendigo, Williamson 11.1918 (BRI).

TASMANIA: Flinders Island, Cleland 11.1912 (AD); Clarke Isle, Maclaine 1893 (MEL); Rocky Cape, Gunn 786/1842, 10.1838 (NSW 125136); Sisters Hills, Black 76.000(4), 1.1948 (MEL); 2 miles [3 km] from Arthur R towards Marrawah, Phillips 11.1965 (CBG 031294); near Granite Point, Bridport, Whaite 2598, 12.1962 (NSW); Low Head, Rupp NSW 125134, 10.1921 (NSW); Port Dalrymple, Brown (BRI, MEL); Georgetown, Stuart (MEL); Kimberley, Black 76.000(3), 11.1915 (MEL); near Perth, South Esk, 10.1848 (MEL); Woolmers, Archer 12.1847 (NSW 125142); Mt Amos, Freycinet Peninsula, Phillips 1.1962 (CBG 003016).

A specimen, Moroka Range, \pm 5 miles $[8 \mathrm{~km}] \mathrm{E}$. of Mt Wellington, Victoria, Beauglehole $43478,11.1973$ (NSW) is very similar to the high mountain forms of $T$. pilosa ssp. pilosa but many of its leaves are opposite or even in whorls and the specimen may represent a high-altitude form of ssp. latifolia.

Tetratheca pilosa var. glabra (incorrectly ascribed to Hooker) Steetz, Familie Tremandreen: 11 (1853) cannot belong to this species, as it has 4 ovules.

Tetratheca ericoides Hort. ex Planch. in Van Houtte, Fl. Serres 10: t. 1065, 229 (1854-1855) is probably T. pilosa of Tasmanian origin. "T. ericoides Gunn mss" is written on MEL 1008301 .

F. Mueller, P1. Indig. Colony Victoria 1: 181 (1860-1862), includes $T$. pilosa in T. ericifolia Sm. Moore \& Betche, Handb. Fl. New South Wales: 36 (1893), also include it in ericifolia but they and all other New South Wales authors would have had $T$. glandulosa Sm., 'T. pilosa var. denticulata', in mind.

Beyond the boundaries set by the two subspecies of $T$. pilosa divergence appears to have continued with $T$. insularis separating in Kangaroo Island, S.A., and $T$. neglecta and T. rubioides in central N.S.W. Perhaps T. bauerifolia is also connected in some way with this group. It has 4 ovules and curved or curled stem-hairs but its calyx and peduncles have the same shining spots so characteristic of the group.

\section{EXCLUDED SPECIES}

Tetratheca oppositifolia Pers., Syn. P1. 1: 419 (1805) is Boronia polygalifolia Sm. (1798). (1845).

Tetratheca verticillata Paxt., Mag. Bot.: 171 (1846) is Platytheca galioides Steetz 


\section{ACKNOWLEDGEMENTS}

The loan of the herbarium collections from the State Herbarium of South Australia, the Queensland Herbarium, Canberra Botanic Gardens, Herbarium Australiense, the National Herbarium of Victoria and the Western Australian Herbarium has been of great assistance and I wish to thank the directors of these institutions most sincerely. I am especially grateful to Miss Helen Aston, a former Australian Botanical Liaison Officer, for examining Type material of Tetratheca ericifolia, $T$. rubioides and $T$. nuda var. spartea. I would also like to acknowledge my indebtedness to Miss Christine Payne who has prepared the drawings and maps for publication. The constructive criticisms from, and helpful discussions with my colleagues at the National Herbarium have been much appreciated.

\section{LITERATURE CITED}

Bentham, G. and Hooker, J. D., 1862-Genera Plantarum 1. London.

Brown, R., 1814 - General Remarks, Geographical and Systematical on the Botany of Terra Australia in Flinders, M., A Voyage to Terra Australis. London.

Hutchinson, J., 1967-Genera of Flowering Plants 2. London.

Smith, J. E., 1805-Exotic Botany 1. London.

Smith, J. E., 1817-Rees Cyclopaedia 35. London. 